\title{
خطة مقترحة لأستثمار المنشأت الرياضية بجامعة أسوان
}

\section{"د/ محمد حامد فنتصي محمد}

المقدمة ومشكثة البحث:

أصبحت الإدارة الحديثة جانباً أساسياً من جوانب النظام الإنتاجي فى أي مجتمع وفى جميع مجالات الحياة الاجتماعية والاقتصادية و السياسية والدينية و الصحية و الرياضية لأنهـ

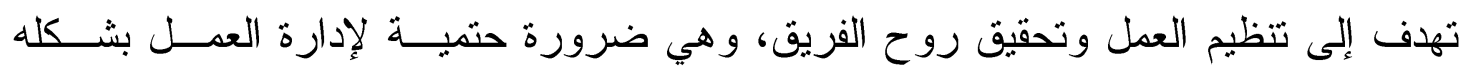
الجماعي و التعاون و التتسيق بين مختلف وظائف العمل بشكل عام وهي العمود الفقري لنجاح الهيئات الرياضية المختلفة بشكل خاص. (9: 1 ( ).

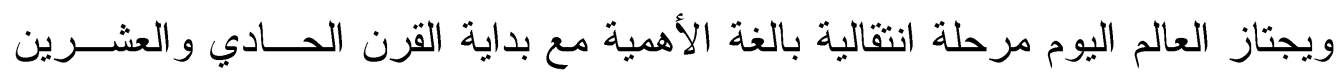
وسط تحو لات دولية وسياسية و اقتصادية انعكست على نواحي الحياة في المجتمعات المختلفة، تمثلت فى ظهور النظام العالمي الجديد، و اقتصاد الســوق، وظهــور التكــتلات الاقتصــــادية

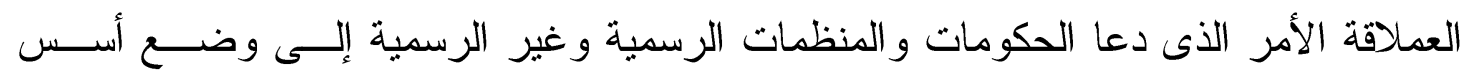

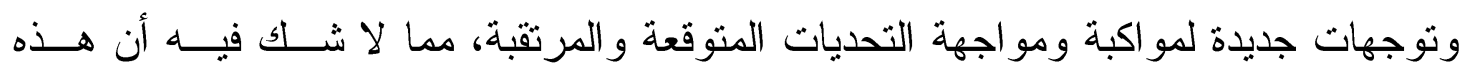
التحولات ستلقي بظلالها على بنية النظام العالمي، و أنماط التفاعلات السائدة فيـــه، و النتــائج و التداعيات المترتبة عليه. (7 (1 : • (1). ومن هذا المنطلق أصبحت الرياضة تعتمد على الاقتصاد لتمويل مختلف الألعاب وذلك

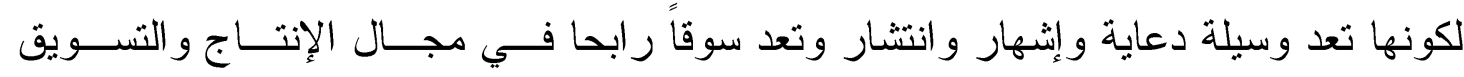

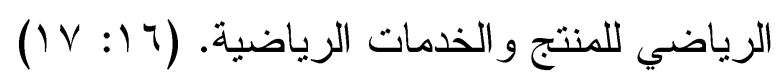

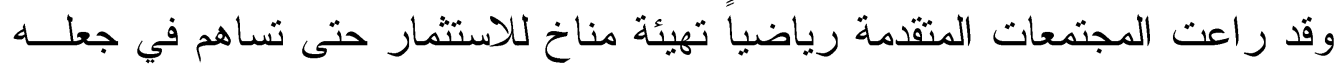
عملاً جدياً من وجهه نظر المستثرين، وتشجيعهم على دخول المجال الرياضي لكي يفيــدوا

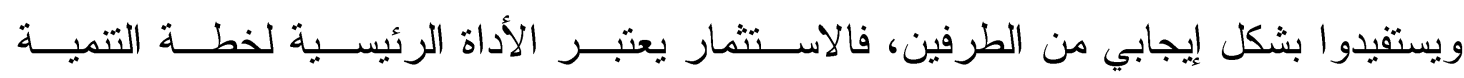

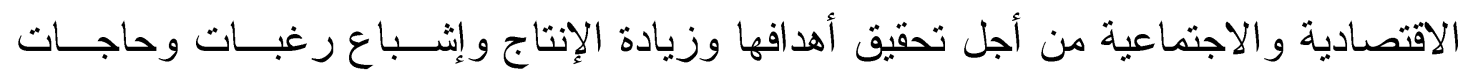
الأفر اد وزيادة قدرة الاقتصاد القومي لمواجهة التحديات وكذلك إيجاد فرص عمل جديدة تساهم فى رفع مستوي المعيشة (1) وتسعى إدارة المنشأت الرياضية إلى تقديم أفضل الخدمات وتحقيق أهدافها ليس على

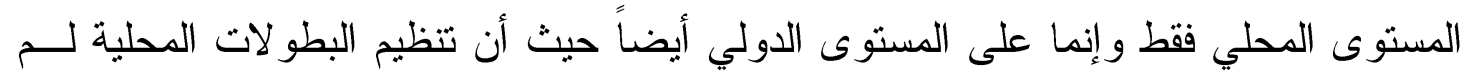
يعد هو أقصى طموح الهيئات و المؤسسات، وتعد المنشأت الرياضية هي التي تعكس مكانــة

" مدرس بقسم الإدارة الرياضية و التزويح- كلية التزبية الرياضية- جامعة أسوان. 


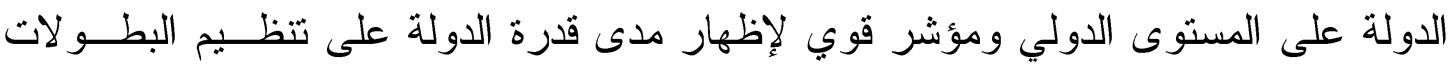

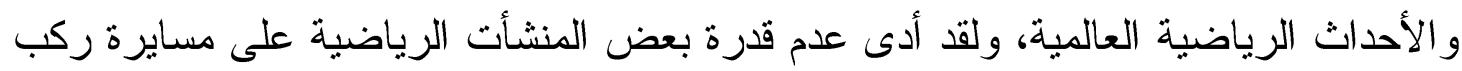

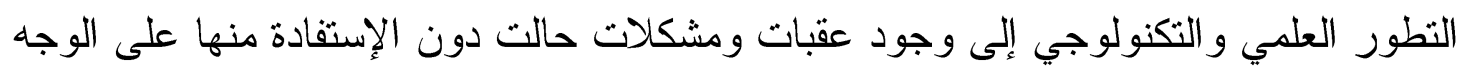

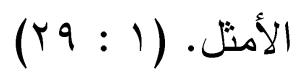

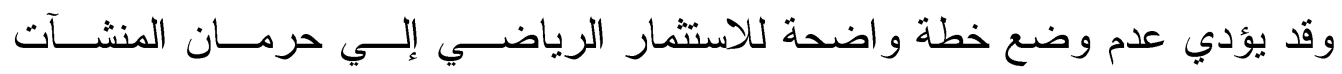

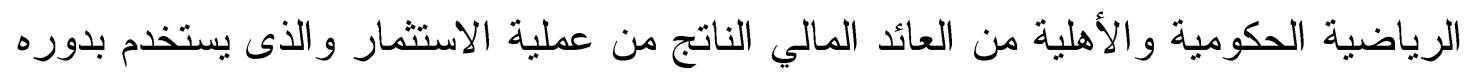

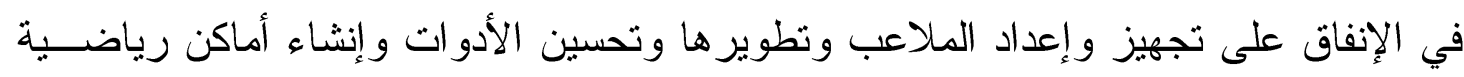

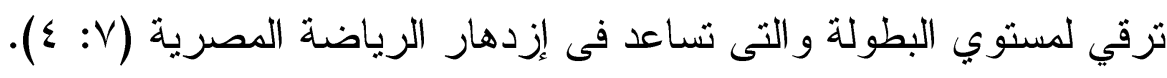

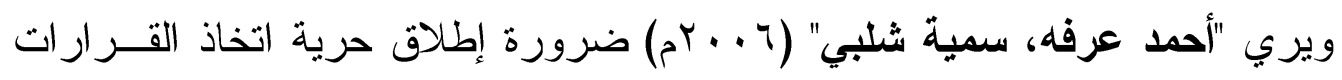

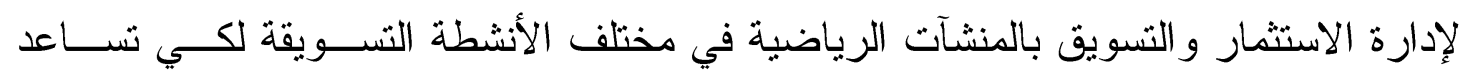

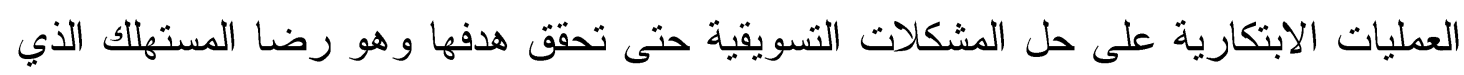

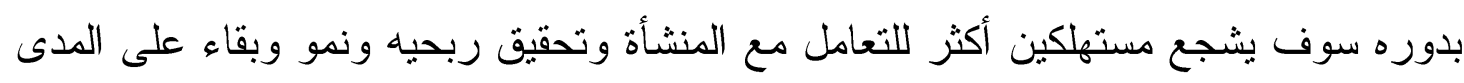
الطويل (ب : 10).

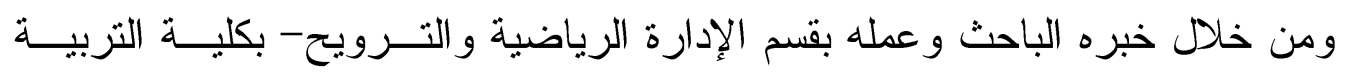

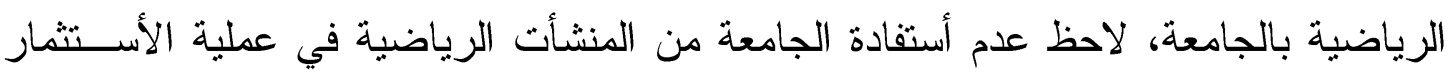

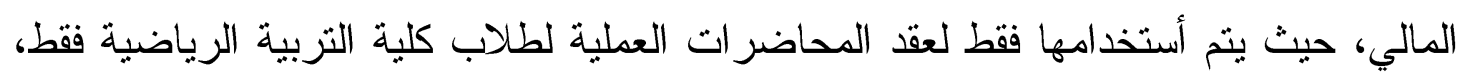

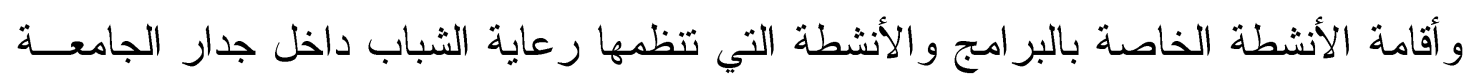

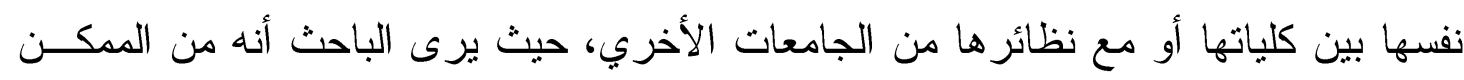

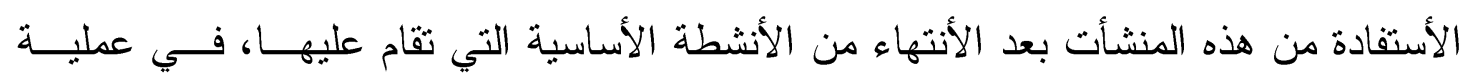

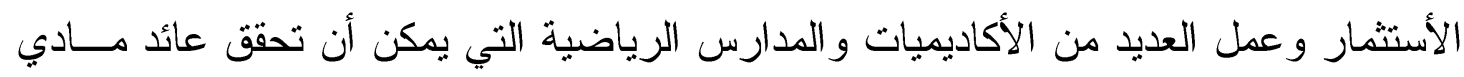

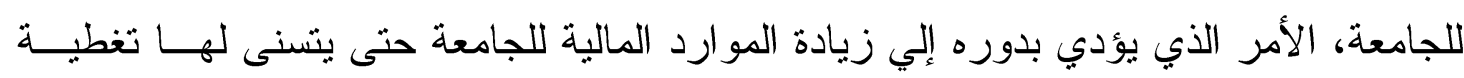

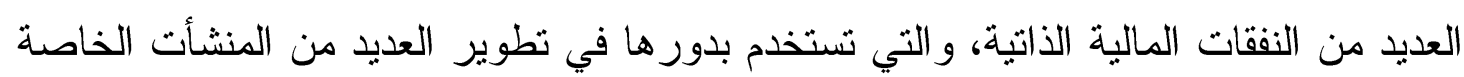

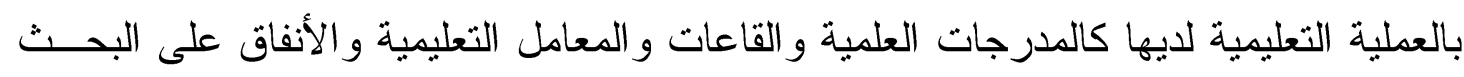

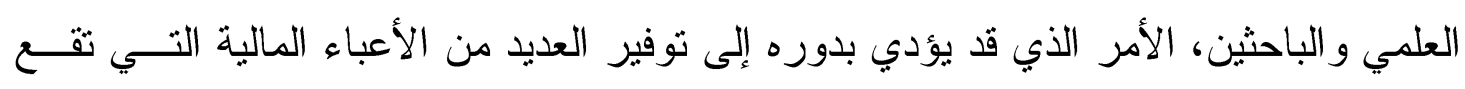

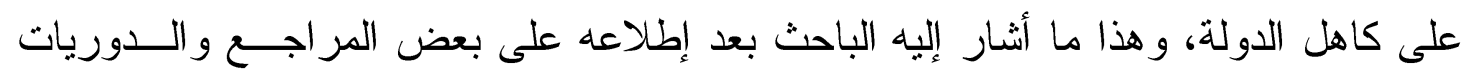

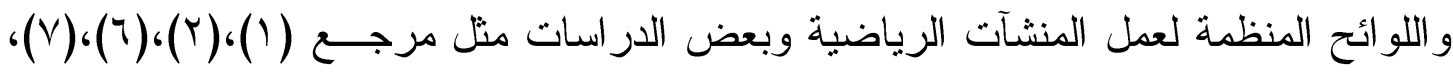

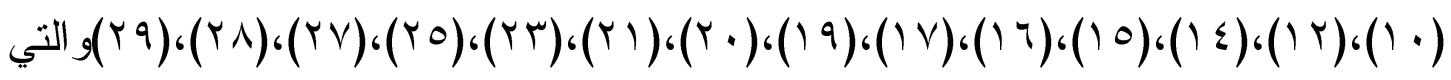

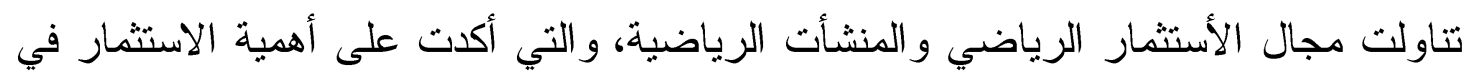

\section{مجلة أسيوط لعلوم وفنوز التربية الرياضية}




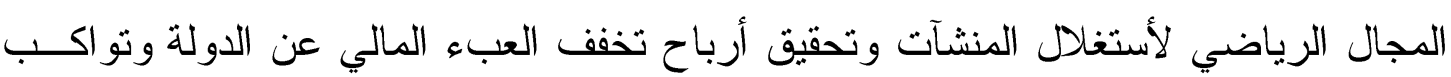

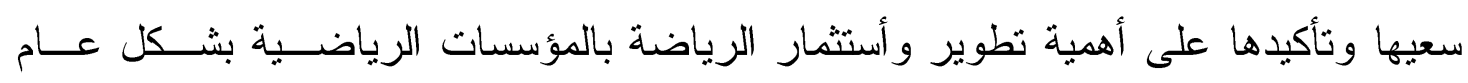

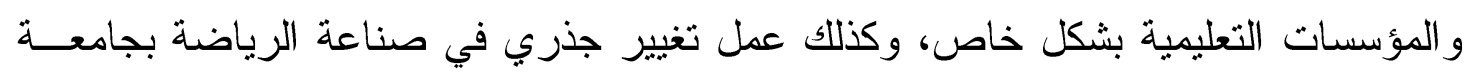

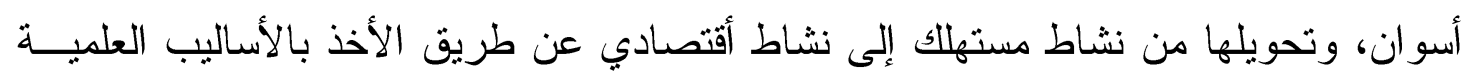
الحديثة في الإدارة و التسويق و الاستثمار .

وقد أصبحت أتجاهات الدولة في الآونة الأخيرة مرتكزة على توسيع قاعدة الأستثمار

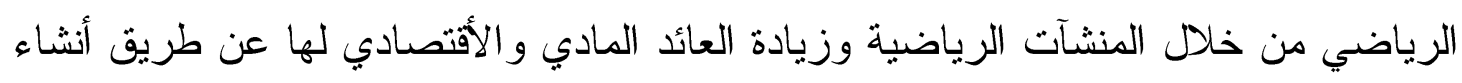

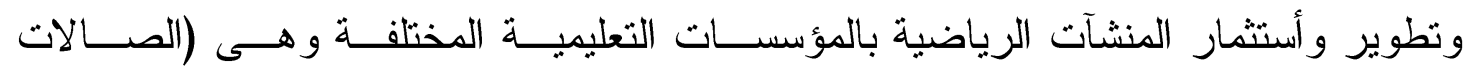

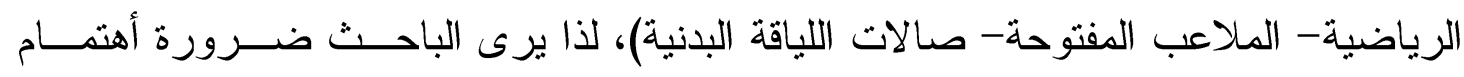

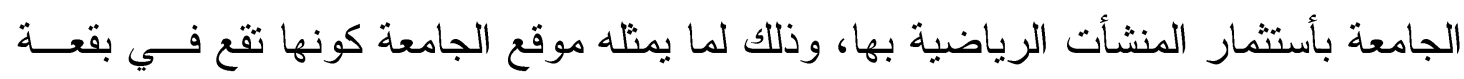

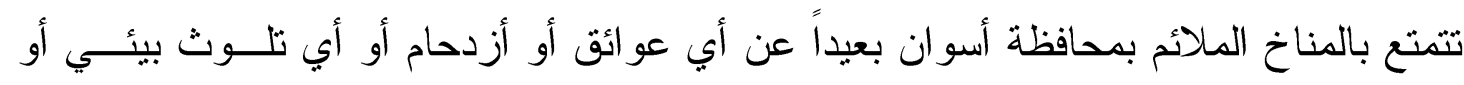
ضوضاء، الأمر الذي يجعلها تعد مصدر جذب لألنتباه الكثير من المستقيدين و المستثمرين.

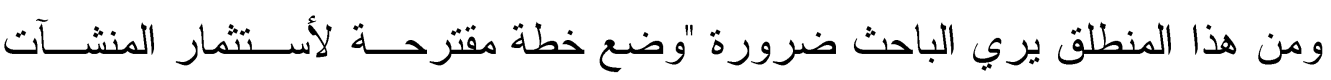

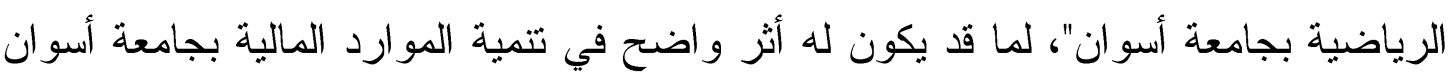

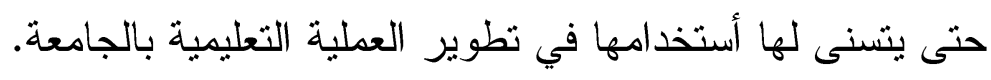
هاف البحث:

يهدف البحث إلى وضع خطة مقترحه لأستثمار المنشآت الرياضية بجامعة أسوان. تساؤلات البحث: 1- ما الو اقع الحالي لخطط الأستثمار الرياضي للمنشأت الرياضية بجامعة أسوان؟

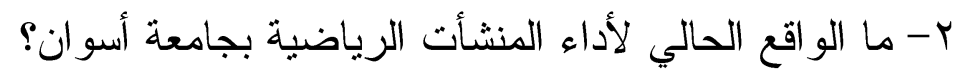

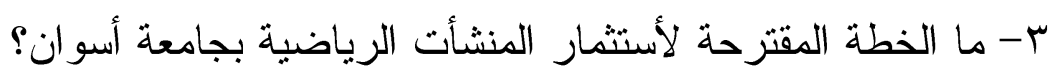
المصطلحات الواردة بالبحث: - الخطة :

هي العمل المخطط القائم على البحث و الدراسة من أجل الكثف عن أفضــل السـبل

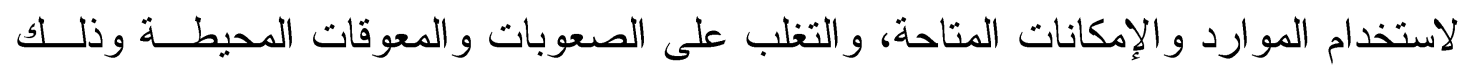
لتأمين الوصول إلى الهدف المحدد. (ع الإد: • ( )

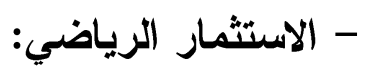
الاستثمار الرياضي وهو الاستفادة من كافة الإمكانات المادية والبشرية فى زيادة العائد

الاقتصادي للهيئة الرياضية من خلال الانشطه الرياضيه المختلفه. (1): 9 (1) 
- المنشآت الرياضية:

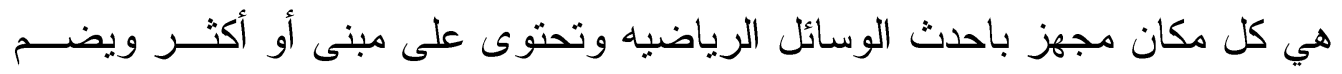

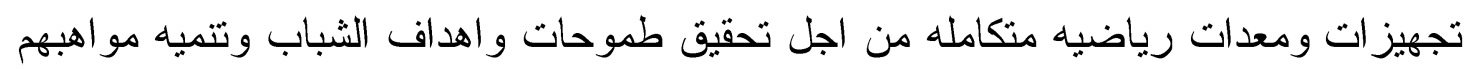

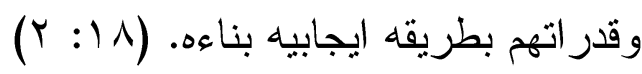

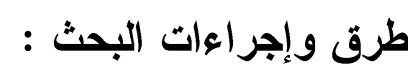
منهج البحث : مرف واجزت

أستخدم الباحث المنهج الوصفي (الدر اسة المسحية) وذلك نظـــراً لملائمتهـــا لطبيعــة

$$
\text { و وأجر اءات البحث . متحمث }
$$

يشتمل مجتمع البحث على الإدارة العليا بجامعة أسوان (مجلس الجامعة)، و أعضـــاء

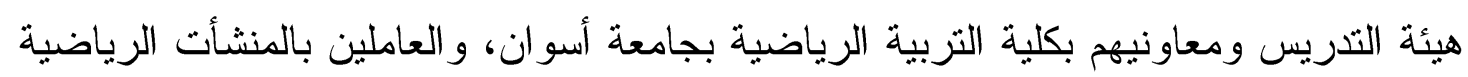

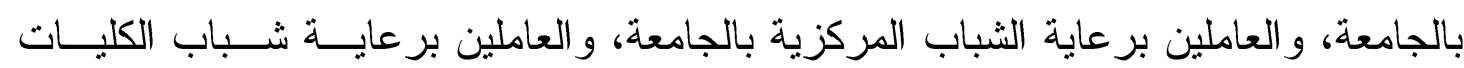

المختلفة.

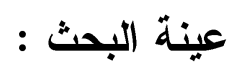

تم اختيار عينة البحث بالطريقة العشوائية من مجتمع البحث من الإدارة العليا بجامعة

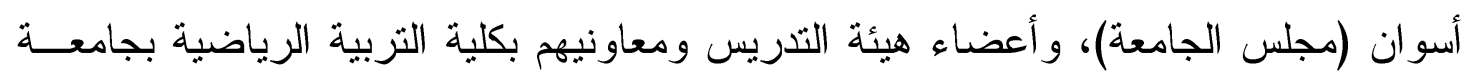

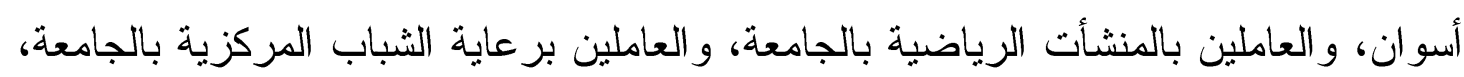

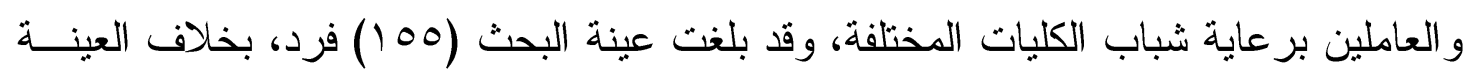

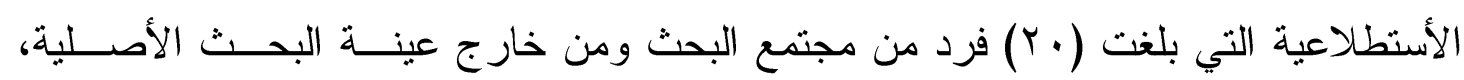

جدول (1) وجدول (1) يوضح التالي:

\begin{tabular}{|c|c|c|c|c|c|}
\hline \multicolumn{6}{|c|}{ عينة البـث } \\
\hline العامبابة & 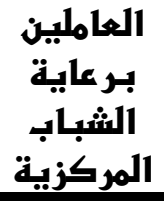 & الرالمنشأئت & 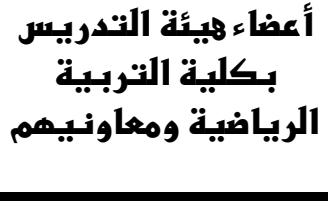 & 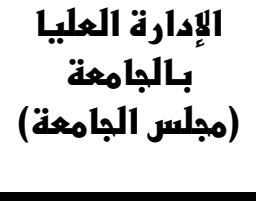 & العينة \\
\hline $0 \leqslant$ & ro & V & rᄉ & m & العدد \\
\hline \multicolumn{5}{|c|}{100} & مجمو ع العينة \\
\hline
\end{tabular}

توصيف عينة البحث

يتضح من الجدول (1) أن إجمالي عينة البحث بلغت (100) فرد، بخــاف العينــة

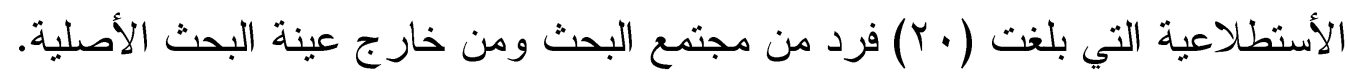
مجلة أسيوط لعلوم وفنوز التربية الرياضية 
أدوات جمع البيانات:

بغرض تحقيق أهداف البحث و الإجابة عن تساؤلاته أستعان الباحث في جمــع بيانــات البحث بالأدو ات التالية: 1- تحليل الوثائق: وقد تمثلت في الآتي: - تحليل المراجع و الدر اسات المرتبطة بموضوع البهاتئ.

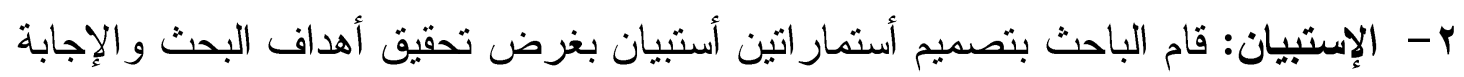

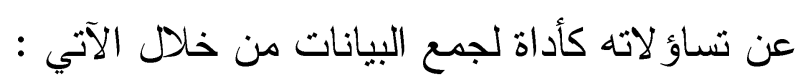
أ- - تصميم أستمارة أستبيان للتعرف على واقع خطط الأستثمار الرياضي للمنشأت الرياضــية بجامعة أسوان. ب- تصميم أستمارة أستبيان للتعرف على و اقع أداء المنشأت الرياضية بجامعة أسوان. أولاً : أستمارة الاستبيان الأولي: - - مواقع خطط الأستثمار الرياضي للمنشأت الرياضية بجامعة أسوان.

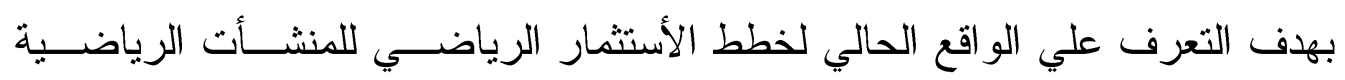
بجامعة أسوان، وبعد تحديد الهدف قام الباحث بالخطو ات التالية: ا

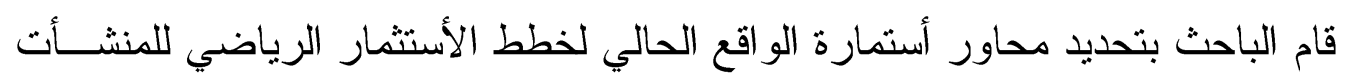
الرياضية بجامعة أسوان في صورتها المبدئية من خلال الأطلاع و التحليل المرجعي للعديد من

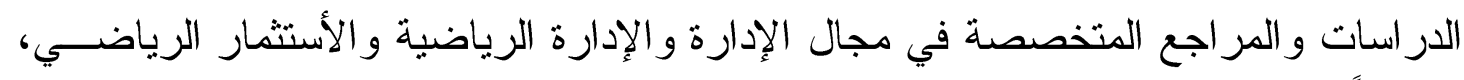

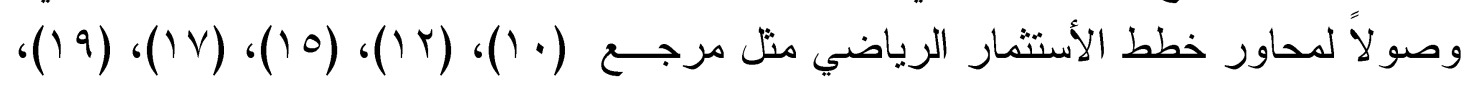

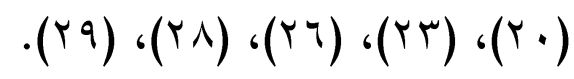
r - عرض المحاور علي الخبراء : قام الباحث بتحديد محاور أستمارة واقع خطط الأستثمار الرياضي للمنشأت الرياضية بجامعة أسوان في صورتها المبدئية مرفق (Y)، وتم عرضها على السادة الخبــر اء و وعـددهم (•) خبر اء درفق (1) بهدف الوصول إلى مدى مناسبة المحاور وكفايتها، حيث لجأ الباحث

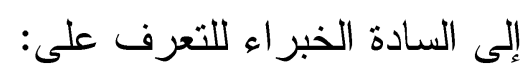
- مدى مناسبة وكفاية المحاور الرئيسية. - تعديل أو حذف أو إضافة ما ير اه الخبير من محاور رئيسية.

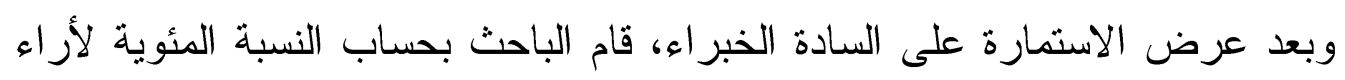
السادة الخبر اء حول المحاور الرئيسية المناسبة وجدول (Y) يوضح ذلك: 


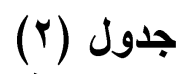

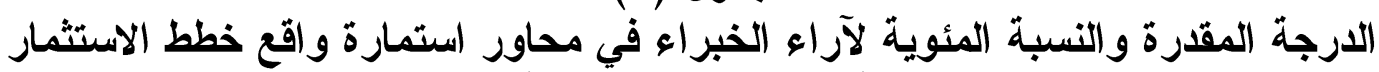

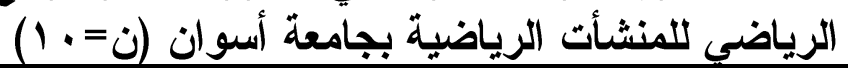

\begin{tabular}{|c|c|c|c|}
\hline النسبة المئوية & 1اتتكرار & المجـــــور & م \\
\hline 9. & 9 & الجو انب القانونية و التشريعية & 1 \\
\hline $1 \ldots$ & 1. & الجو انب الإدارية & r \\
\hline 9. & 9 & الجو انب الفنية & $r$ \\
\hline $1 \ldots$ & 1. & جو انب الو عي بالإستثمار الرياضي & $\varepsilon$ \\
\hline v. & $\mathrm{V}$ & جو انب الوعى بالسياسة الرياضية & 0 \\
\hline$\varepsilon$. & $\varepsilon$ & جو انب متعلقة بالجمهور & 7 \\
\hline 7. & 7 & جو انب متعلقة بالجهة الإدارية والرقابية & $\mathrm{v}$ \\
\hline
\end{tabular}

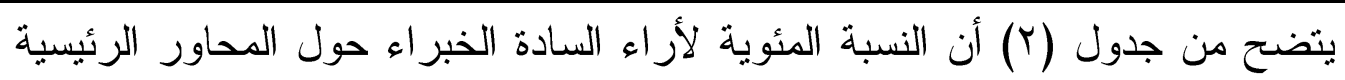

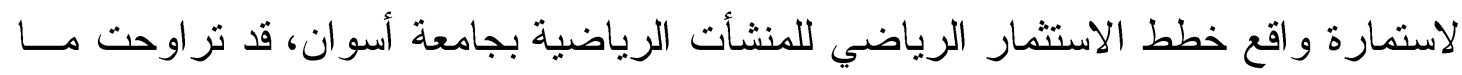

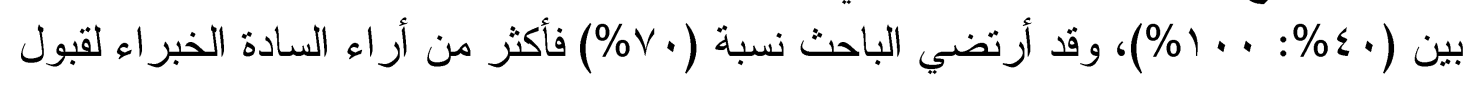

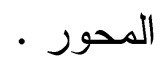
وبالتالي تم حذف المحور رقم (T)، (V) من أسنمارة أستبيان واقع خطط الأســتثمار

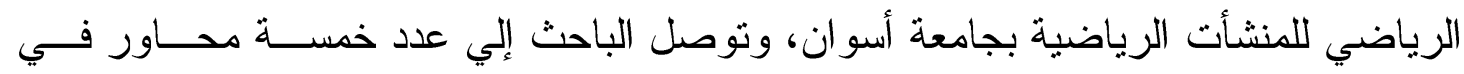

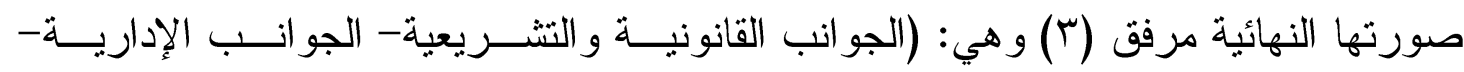

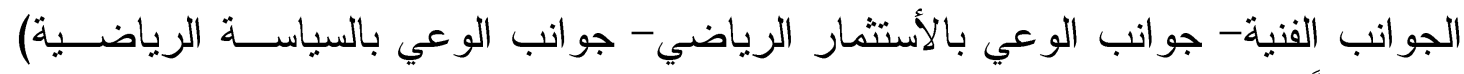
وذللك وفقاً لأر اء السادة الخبر اءواء. r- إعداد عبارات الاستبيان:

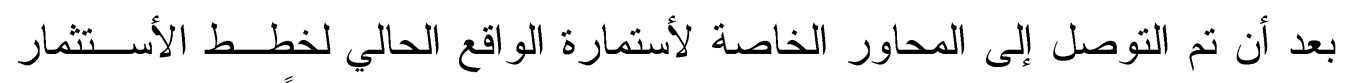

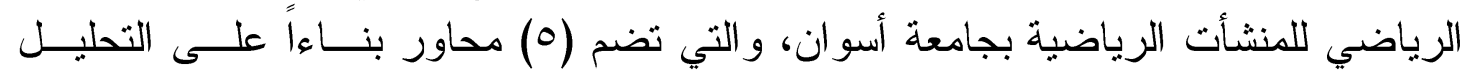

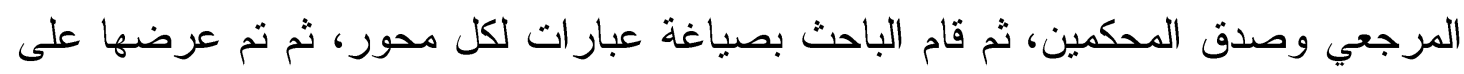

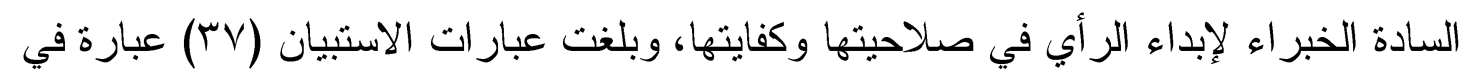

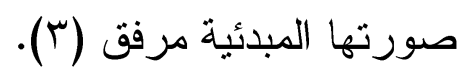
ـ - المعاملات العلمية لأستمارة الأستبيان:

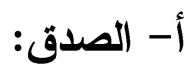
- صدق المحكمين:

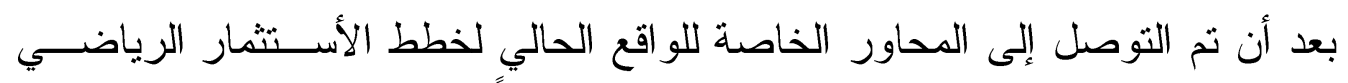

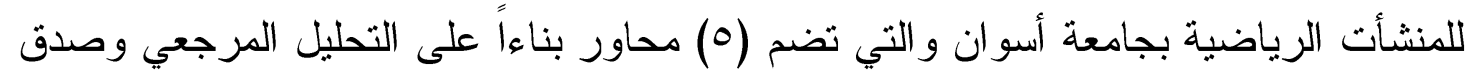

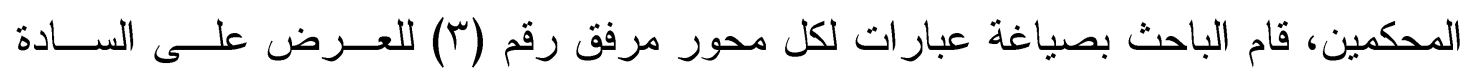

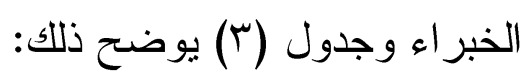




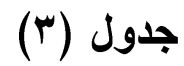

النسبة المئوية لآراء الخبراء في عبارات استمارة الواقع الحالي لخطط الأستثمار الرياضي

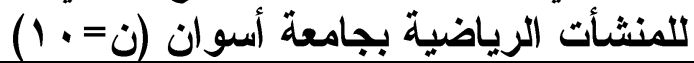

\begin{tabular}{|c|c|c|c|c|c|c|c|c|c|}
\hline \multicolumn{2}{|c|}{ 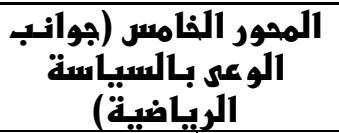 } & \multicolumn{2}{|c|}{ 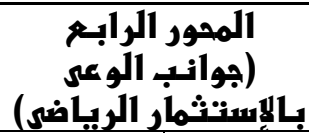 } & \multicolumn{2}{|c|}{ 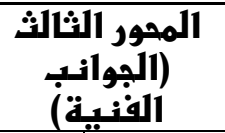 } & \multicolumn{2}{|c|}{ المهور الثانبي } & \multicolumn{2}{|c|}{ 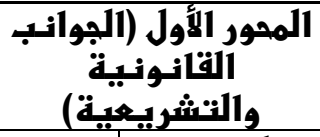 } \\
\hline$\%$ & العبارة & $\%$ & ألعبارة & $\%$ & العبارة & $\%$ & العبارةة & $\%$ & العبارةة \\
\hline $1 \ldots$ & 1 & $1 \ldots$ & 1 & 9. & 1 & $1 \ldots$ & 1 & $1 \ldots$ & 1 \\
\hline$\Lambda$. & $Y$ & 9. & $r$ & $1 \ldots$ & $r$ & $\varepsilon$. & $r$ & 9. & $Y$ \\
\hline $1 \ldots$ & $\mu$ & $1 \ldots$ & $r$ & $1 \ldots$ & $r$ & 7. & $\mu$ & 7. & $\mu$ \\
\hline$\Lambda$. & $\varepsilon$ & $\Lambda$. & $\varepsilon$ & 7. & $\varepsilon$ & $V$. & $\varepsilon$ & $1 \ldots$ & $\varepsilon$ \\
\hline \multirow[t]{6}{*}{$\Lambda$. } & 0 & 0. & 0 & $\varepsilon$. & 0 & $1 \ldots$ & 0 & A. & 0 \\
\hline & & $1 \ldots$ & 7 & 7. & 7 & 9. & 7 & $V$. & 7 \\
\hline & & & & $\Lambda$. & V & 7. & V & 0. & V \\
\hline & & & & 9. & $\Lambda$ & 9 . & $\Lambda$ & A. & $\Lambda$ \\
\hline & & & & & & V. & 9 & & \\
\hline & & & & & & ᄉ. & 1. & & \\
\hline
\end{tabular}

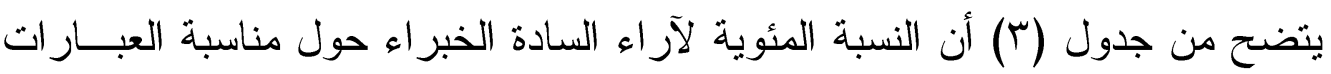

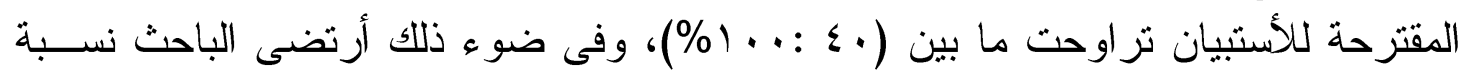

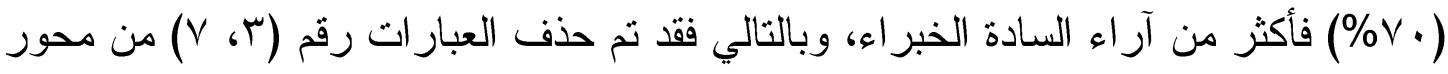

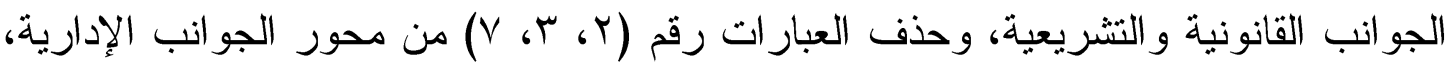

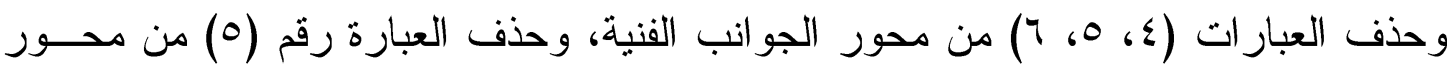

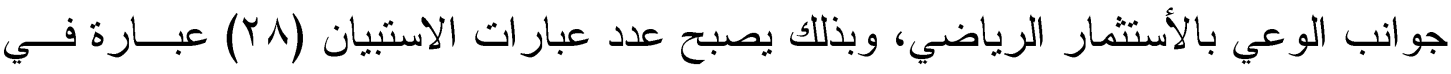

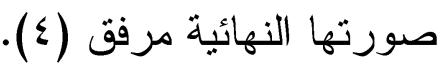

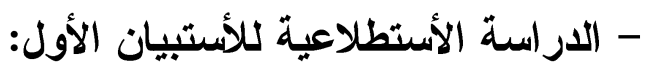

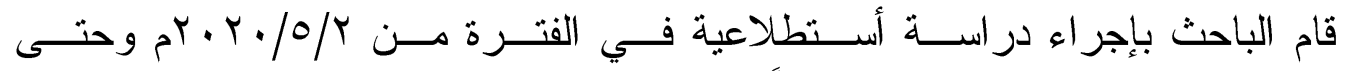

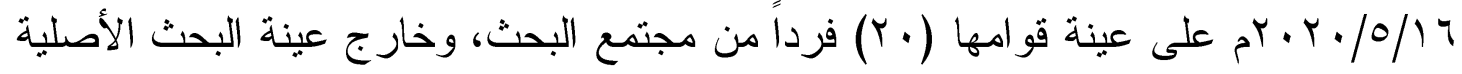

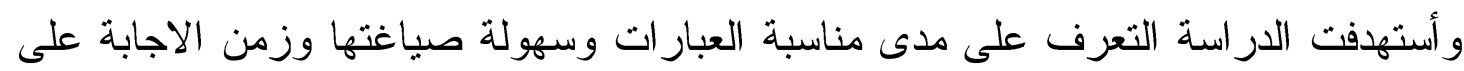

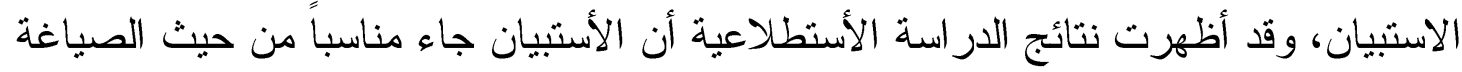

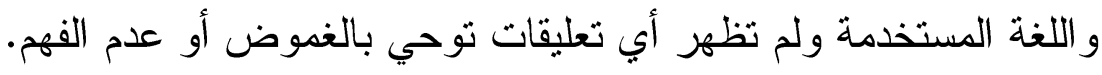

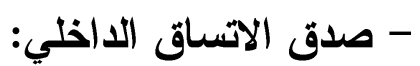
أستخدم الباحث صدق الأتساق الداخلي لحساب معامل الصدق للأستبيان وذلك بهــــ

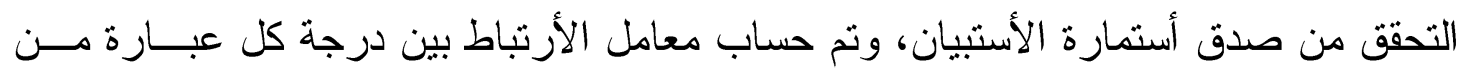

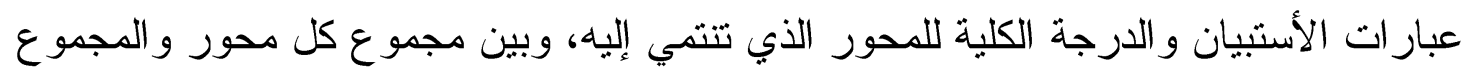

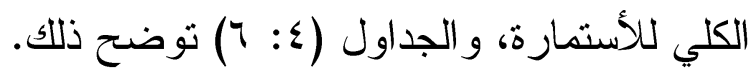




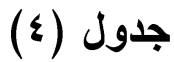

معاملات الأرتباط بين العبارات ومجموع المحور المنتمية إليه لاستمارة الواقع الحإن الحالي لخطط

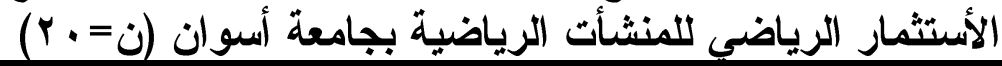

\begin{tabular}{|c|c|c|c|c|c|c|c|c|c|}
\hline \multicolumn{2}{|c|}{ 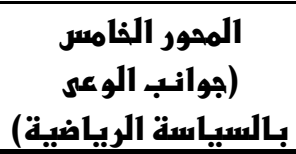 } & \multicolumn{2}{|c|}{ 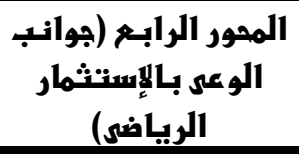 } & \multicolumn{2}{|c|}{ (الجوانـب الفنـبة) } & \multicolumn{2}{|c|}{ (الجوانب المهور الثانبي. } & \multicolumn{2}{|c|}{ 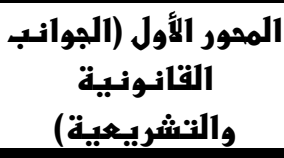 } \\
\hline الارتباط & العبارة رقم & 1العامل تباط & العبارة & 1الارتباط & رقلمبارة & 11 معامل & رقلمبارة & 11 معامل & العبارةة \\
\hline$* * \cdot, 9 \leq r$ & 1 & $* * ., 90 \mathrm{~V}$ & 1 & $* * \cdot, 9 \cdot r$ & 1 & **,$\wedge T r$ & 1 & $* * ., 97$. & 1 \\
\hline$\star *,, 9 \leq 1$ & $r$ & $\star *,, \vee \wedge \circ$ & r & $* * ., 977$ & r & "ז • & r & $* *, \wedge 9 \mathrm{~V}$ & $r$ \\
\hline$\star \star, \wedge 9 V$ & r & $\star * ., 90 \mathrm{~V}$ & $r$ & $\star *,, 9 r r$ & r & **, $\wedge \nmid q$ & $\mu$ & $* *, 97 \mathrm{~V}$ & $\mu$ \\
\hline$\star \star \star, \wedge \leq$. & $\varepsilon$ & $* *,, T V V$ & $\varepsilon$ & **., $9 \mu$. & $\varepsilon$ & **., $9 Y 7$ & $\varepsilon$ & $\star * *, \wedge \wedge$. & $\varepsilon$ \\
\hline$* *, q, V$ & 0 & $\star * ., 91 \leq$ & 0 & **.,977 & 0 & **., 947 & 0 & $* *,, 9 \leqslant \leqslant$ & 0 \\
\hline & & & & & & $\star * ., 90 r$ & 7 & $* *,, 101$ & 7 \\
\hline & & & & & & $* \star ., 97 r$ & V & & \\
\hline
\end{tabular}

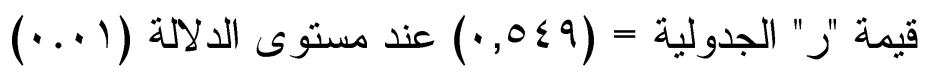

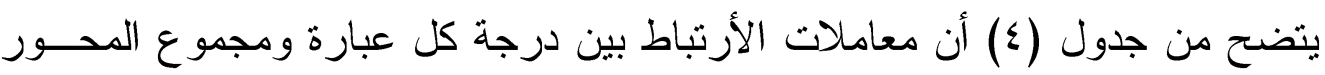

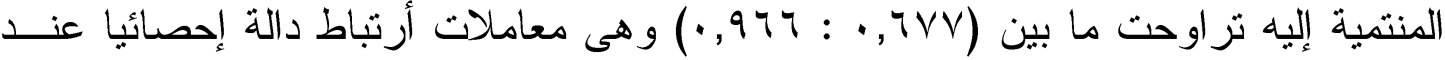

مستوى الدلالة (1 ...)، مما يشير إلى صدق الأتساق الداخلي لعبار ات كل محور.

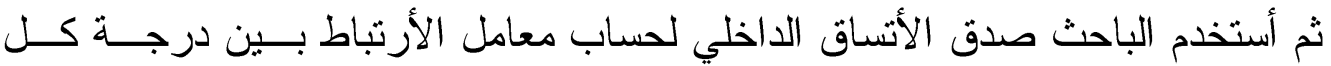

عبارة و الدرجة الكلية للأستبيان، وجدول (0) يوضح ذلك.

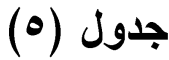

معاملات الأرتباط بين درجة كل عبارة و الارجة الكلية للانتبيان (ن= • آب)

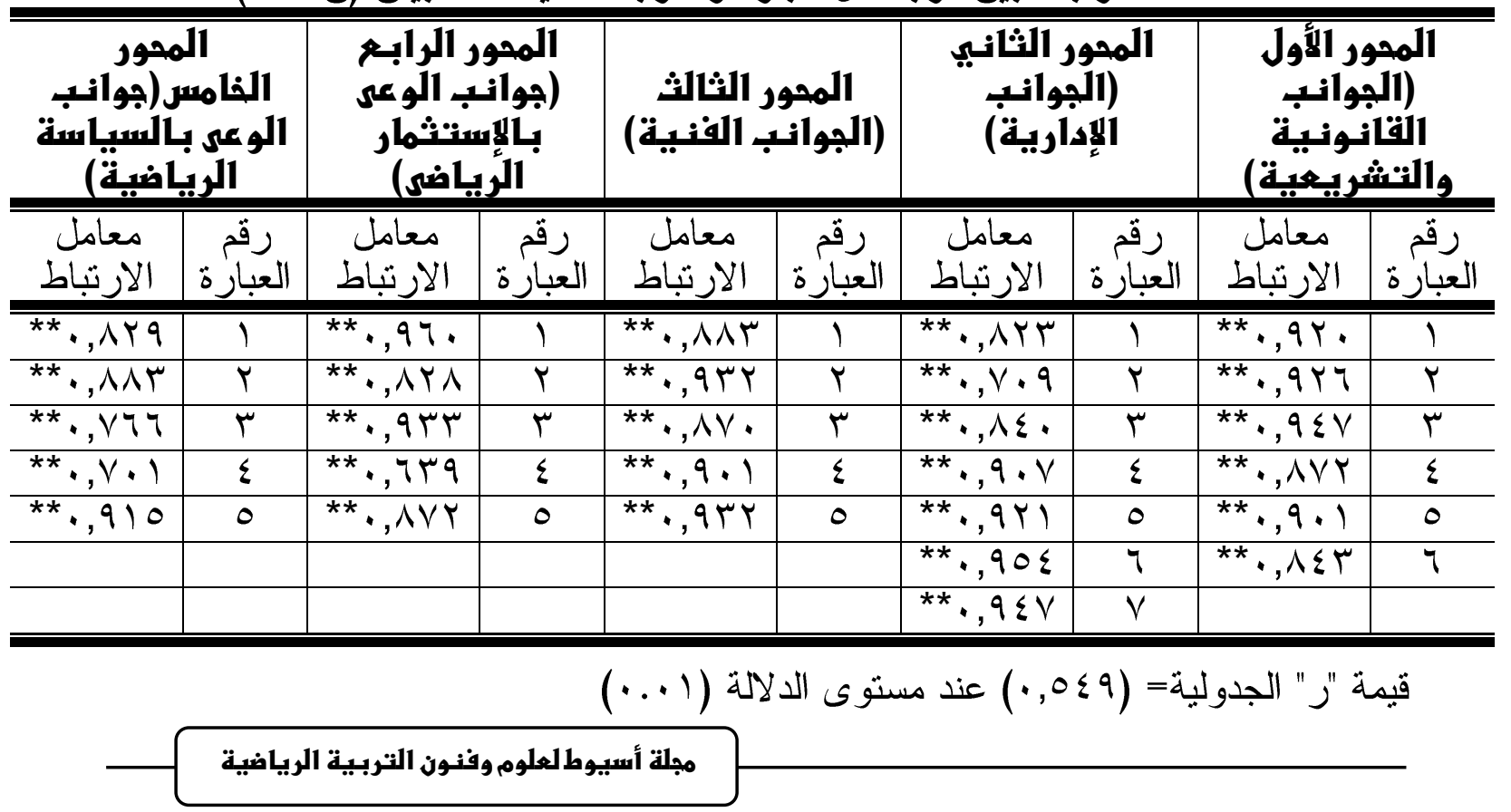


يتضح من جدول (0) أن معاملات الأرتباط بين درجة كل عبارة و الدرجــة الكليـة

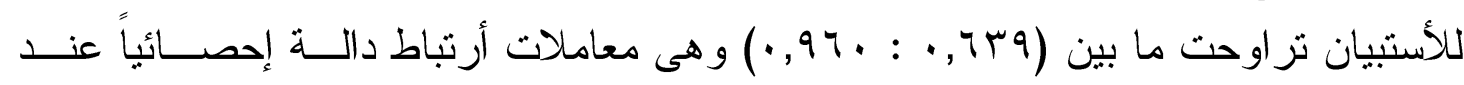
مستوى الدلالة (1 . . .)، مما يشير إلى صدق الأتساق الداخلي لعبار ات الأستبيان ككل.

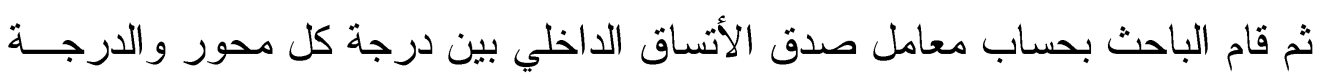

الكلية للأستبيان، للتأكيد على صدق محاور الأستبيان قيد البحث، كما هو موضح بجدول (T).

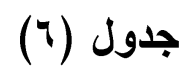

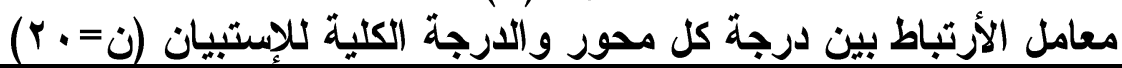

\begin{tabular}{|c|c|c|c|}
\hline معامل الار تباط & عدد العبارات & المحاور & م \\
\hline$* * \cdot, q \wedge r$ & 7 & الجو انب القانونية و التشريعية & 1 \\
\hline$\star * *, 9 \wedge$. & $\mathrm{V}$ & الجو انب الإدارية & $r$ \\
\hline$* * ., 970$ & 0 & الجو انب الفنية & r \\
\hline${ }^{* *} \cdot, 9 \wedge r$ & 0 & جو انب الوعى بالإستثمار الرياضـى & $\varepsilon$ \\
\hline$* * \cdot, 9 \cdot 7$ & 0 & جو انب الوعى بالسياسة الرياضية & 0 \\
\hline \multicolumn{2}{|c|}{ 1 Y عبارة } & \multicolumn{2}{|l|}{ مجمو ع العبار ات } \\
\hline
\end{tabular}

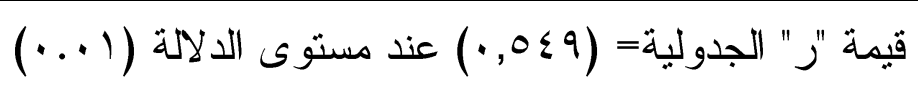

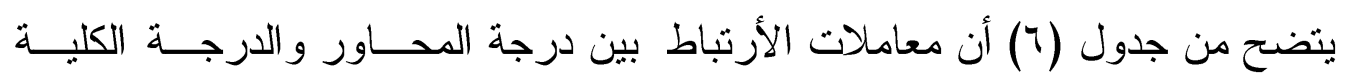

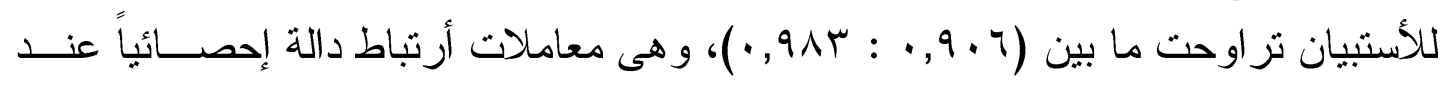
مستوى (1 . . •)، مما يشير إلى الأتساق الداخلي للأستبيان ككل.

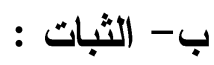

قام الباحث بايجاد معامل الثبات للأستبيان من خلال معامـلـل ثبــات ألفـــا كرونبـــاخ

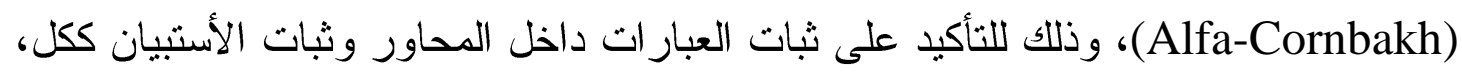

جدول (V)

كما هو موضتح بجدول (V).

معامل ثبات ألفا كرونباخ لأستبيان الواقع الحالي لخطط الأستثمار الرياضي للمنشأث

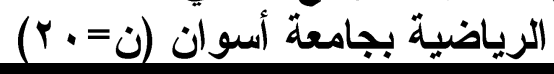

\begin{tabular}{|c|c|c|c|}
\hline معامل ثبات ألها كرو نباذ & عدد العبارات & المحـــــور & م \\
\hline., 97. & 7 & الجو انب القانونية و التشريعية & 1 \\
\hline $.90 \mathrm{~V}$ & V & الجو انب الإدارية & $r$ \\
\hline$\cdot, 97 \leq$ & 0 & الجو انب الفنية & $r$ \\
\hline$\cdot, v \leq r$ & 0 & جو انب الوعى بالإستثمار الرياضى & $\varepsilon$ \\
\hline$\cdot, 9 \leq 1$ & 0 & جو انب الوعى بالسياسة الرياضية & 0 \\
\hline$\cdot, 9 \wedge 0$ & rᄉ & المجمو ع & \\
\hline
\end{tabular}

مجلة أسيوط لعلوم وفنـوز التربية الرياضية 


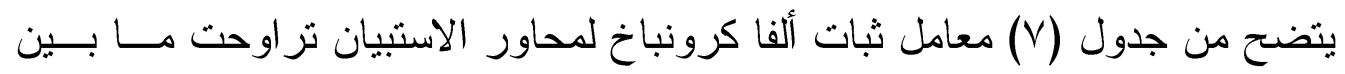

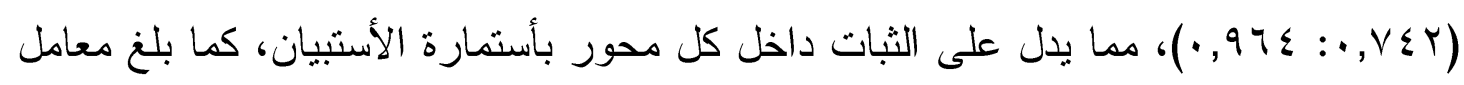

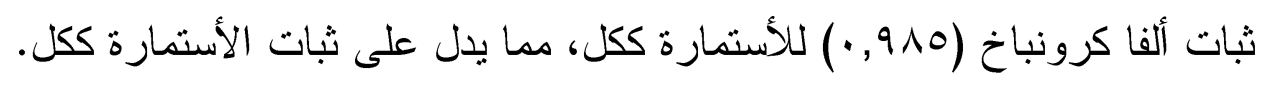
- نطبيق الأستبيان في صورته النهائية:

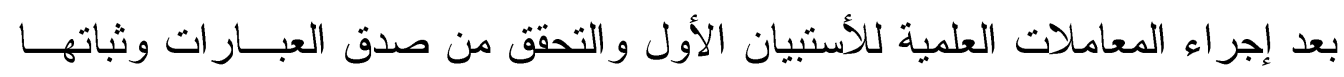

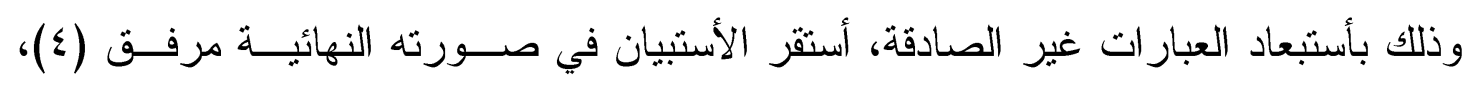

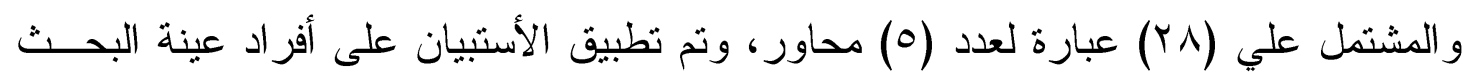

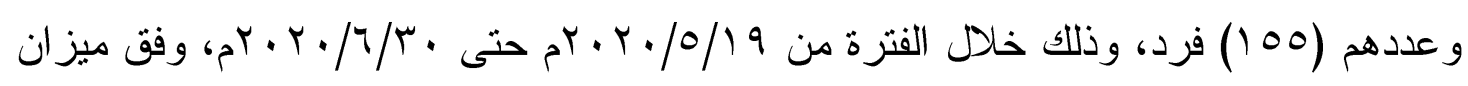

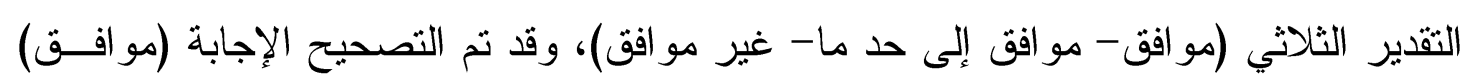

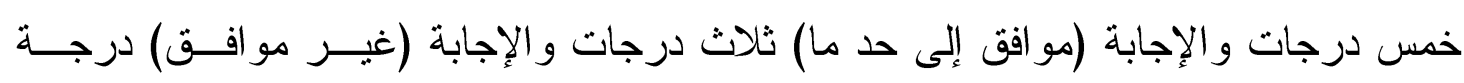

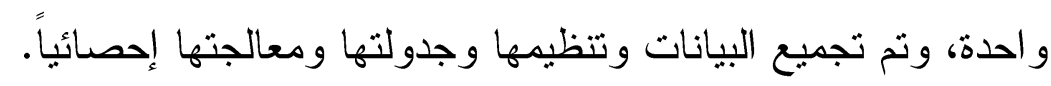
ثانياً: أستمارة الأستبيان الثانية: الأنان

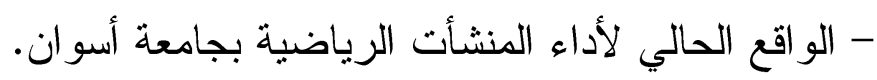

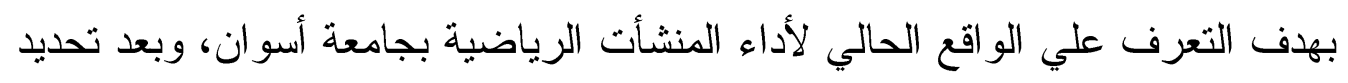
الهدف قام الباحث بالخطوات التالية:

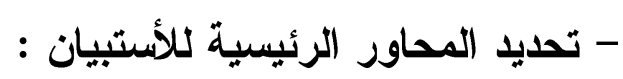

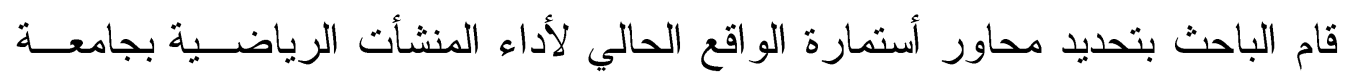

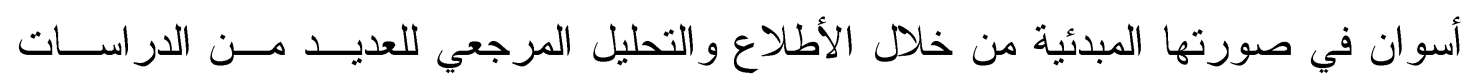

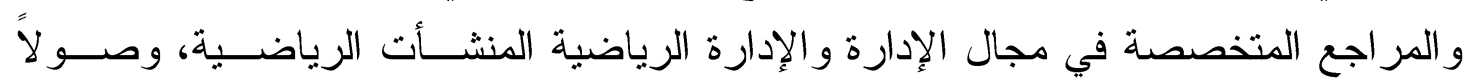

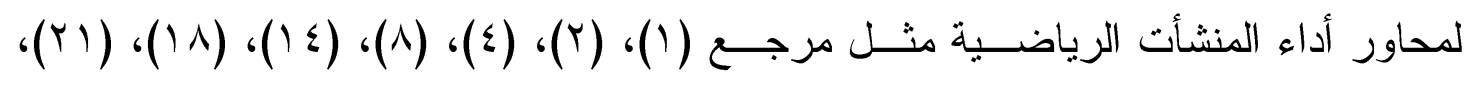
. (rT)، (ro) ( $)$ ( $)$

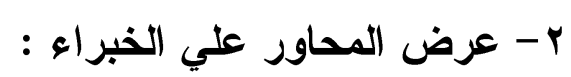

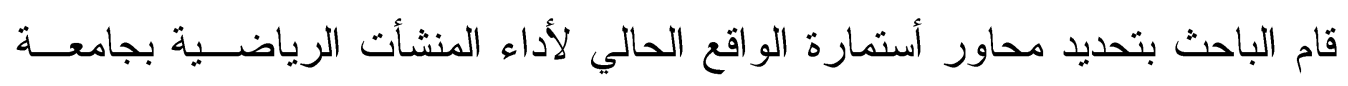

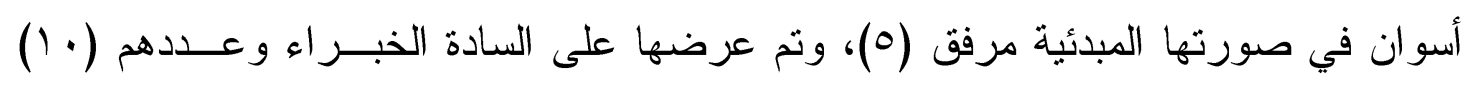

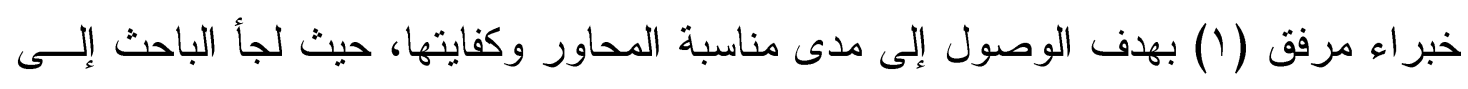

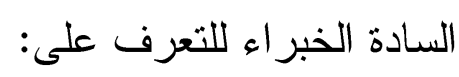
- مدى مناسبة وكفاية المحاور الرئيسية. - تعديل أو حذف أو إضافة ما ير اه الخبير من محاور رئيسية. 
وبعد عرض الأستمارة على السادة الخبراء، قام الباحث بحساب النسبة المئوية لأراء السادة الخبر اء حول المحاور الرئيسية المناسبة وجدول (^) يوضح ذلك:

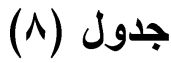

الارجة المقدرة والنسبة المئوية لآراء الخبراء في محاور استمارة الواقع الحالي لأداء

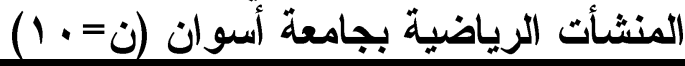

\begin{tabular}{|c|c|c|c|}
\hline النيسبة المئوبة & التكرار & 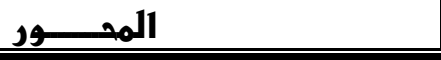 & م \\
\hline 9. & 9 & المفاهيم & 1 \\
\hline $1 \ldots$ & 1. & التخطيط & $r$ \\
\hline $1 \ldots$ & 1. & الأمكانات & $r$ \\
\hline $1 \ldots$ & 1. & التتظيم & $\varepsilon$ \\
\hline
\end{tabular}

يتضح من جدول (^) أن النسبة المئوية لأراء السادة الخبراء حول المحاور الرئيسية

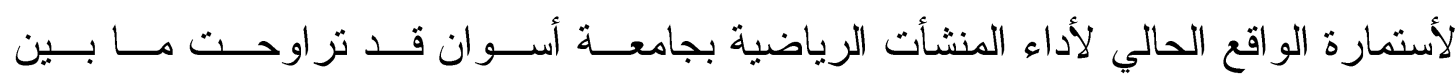

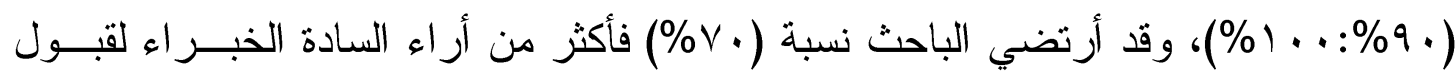
المحور

وبالتالي تم قبول جميع المحاور لأستثارة الو اقع الحــالي لأداء المنشــأت الرياضــية

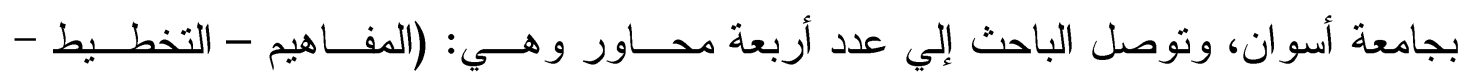

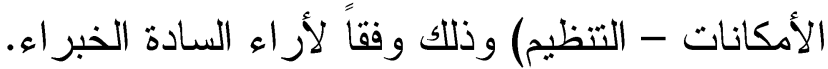
r- إعداد عبار ات الاستبيان:

بعد أن تم التوصل إلى المحاور الخاصدة لأستمارة الواقــع الحــالي لأداء المنشــأث

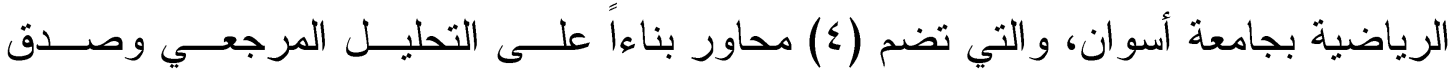
المحكمين، قام الباحث بصياغة عبار ات لكل محور، ثم تم عرضها على السادة الخبر اء لإبداء

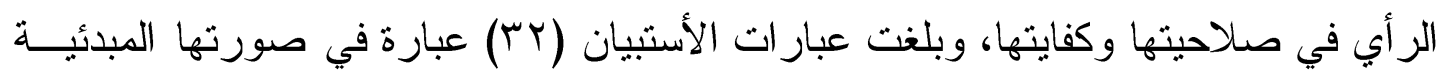

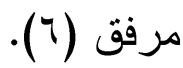
ع - المعاملات العلمية لأستمارة الأستبيان:

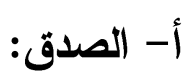

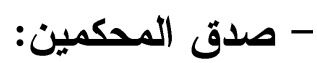
بعد أن تم التوصل إلى المحاور الخاصة بالو اقع الحـــالي لأداء المنشــأت الرياضـــية بجامعة أسوان، والتي تضم (ع) محاور بناءاً على التحليل المرجعي وصدق المحكمين، قـام

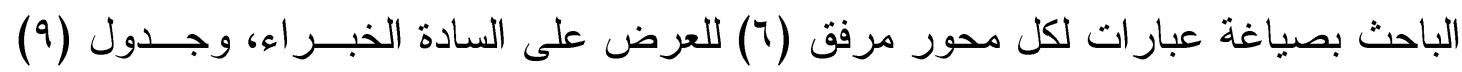
يوضتح ذللك: 


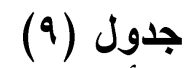

النسبة المئوية لآراء الخبراء في عبارات أستمارة الواقع الحالي لأداء المنشأت الرياضية

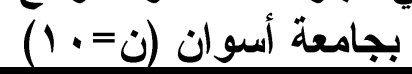

\begin{tabular}{|c|c|c|c|c|c|c|c|}
\hline \multicolumn{2}{|c|}{ التنـظليم } & \multicolumn{2}{|c|}{ 1الأمكانات } & \multicolumn{2}{|c|}{ التنطبيط } & \multicolumn{2}{|c|}{ المغاهيمم } \\
\hline$\%$ & العبارة & $\%$ & العبارة & $\%$ & العبارة & $\%$ & العبارة \\
\hline $1 \ldots$ & 1 & 9. & 1 & $V$. & 1 & A. & 1 \\
\hline 9. & $r$ & 9. & $r$ & 9. & $r$ & ᄉ. & $r$ \\
\hline A. & r & $1 \ldots$ & $\mu$ & A. & $r$ & $1 \ldots$ & $r$ \\
\hline A. & $\varepsilon$ & 9. & $\varepsilon$ & 7. & $\varepsilon$ & 0. & $\varepsilon$ \\
\hline A. & 0 & 0. & 0 & $1 \ldots$ & 0 & $1 \ldots$ & 0 \\
\hline 0. & 7 & 7. & 7 & 9. & 7 & ᄉ. & 7 \\
\hline 0. & V & A. & V & 7. & V & & \\
\hline $1 \ldots$ & $\Lambda$ & 0. & $\Lambda$ & 9. & $\Lambda$ & & \\
\hline & & & & 0. & 9 & & \\
\hline & & & & 7. & 1. & & \\
\hline
\end{tabular}

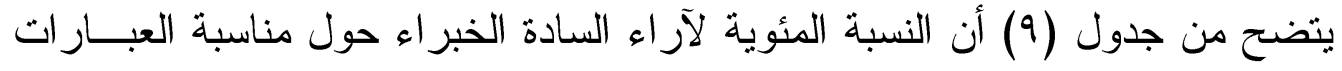

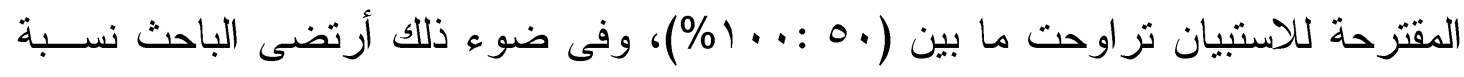

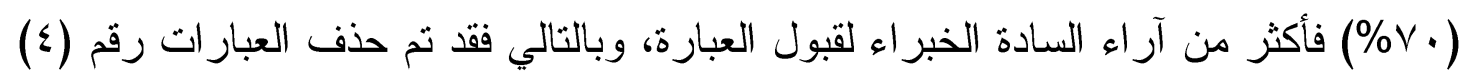

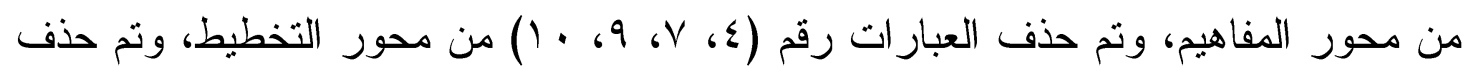

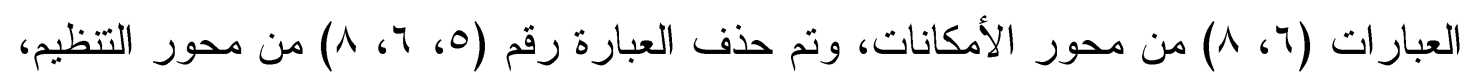

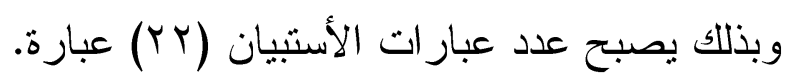
- الاراسة الإستطلاعية للأستبيان الثاني:

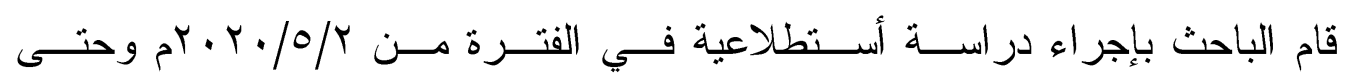

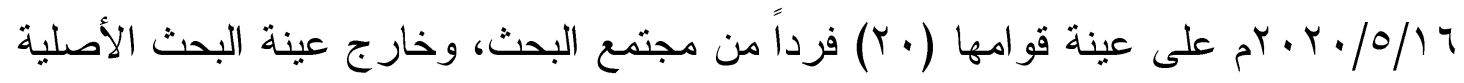

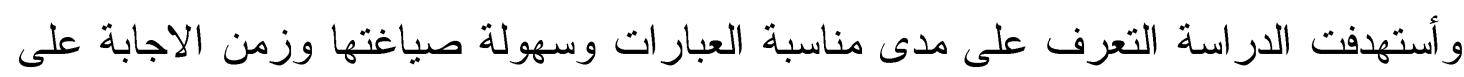

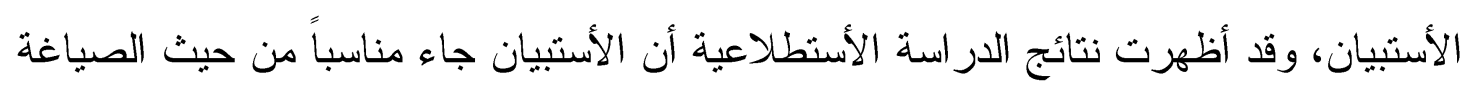
و اللغة المستخدمة ولم تظهر أي تعليقات توحي بالغموض أو أو عدم الفهم. - مدق الاتساق الاخلي:

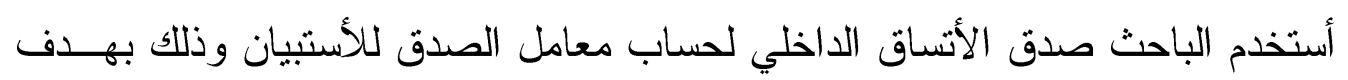

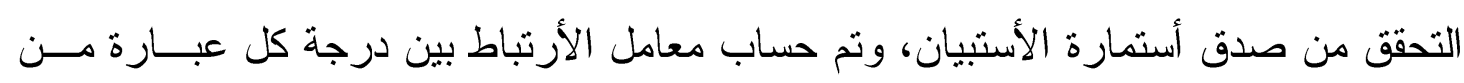

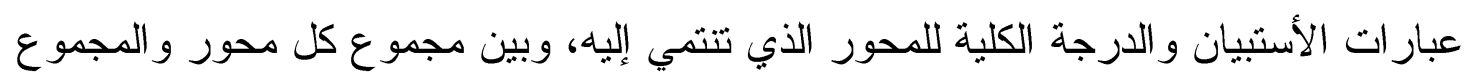

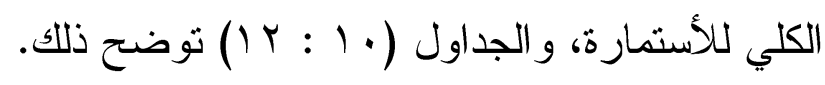




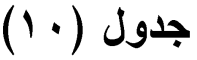

معاملات الأرتباط بين العبارات ومجموع المحور المنتمية إليه لأستمارة الواقع الحالي لأداء

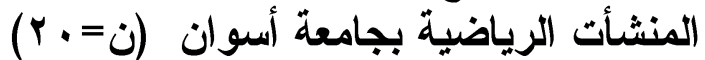

\begin{tabular}{|c|c|c|c|c|c|c|c|}
\hline \multicolumn{2}{|c|}{ المهور الرابـم } & \multicolumn{2}{|c|}{$\begin{array}{l}\text { المهور الثانات) } \\
\text { (المكانات }\end{array}$} & \multicolumn{2}{|c|}{ 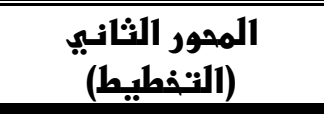 } & \multicolumn{2}{|c|}{ المحور الأول (المفاهيمم) } \\
\hline معامل & العبارة & 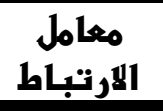 & العبارة & 118امل & العبارةة & 118 الارنباط & العبارة \\
\hline$\star \star *, 9 \leq \Lambda$ & 1 & **., $9 \leq \leq$ & 1 & ${ }^{* *} \cdot, 9 \vee V$ & 1 & ${ }^{* *} \cdot, 9 \vee 0$ & 1 \\
\hline$* * ., 901$ & $r$ & $\star * \cdot, \wedge \wedge 9$ & $r$ & $* *, \wedge 9 r$ & $r$ & $* * \cdot, 917$ & $r$ \\
\hline${ }^{* *} \cdot, 1,07$ & $r$ & **,,人тr & $r$ & ${ }^{* *} \cdot, 109$ & $r$ & $* * \cdot, 97 \varepsilon$ & $r$ \\
\hline$\star * *, 9 \leq \Lambda$ & $\varepsilon$ & $\star \star *, \wedge 9$. & $\varepsilon$ & $* * \cdot, 9 \vee V$ & $\varepsilon$ & $* *, \wedge 9 \mu$ & $\varepsilon$ \\
\hline$\star * *, T \leq Y$ & 0 & **.,9ro & 0 & $* * \cdot, 9 \leq 9$ & 0 & **.,9Y7 & 0 \\
\hline **.,9r. & 7 & & & $* \star \cdot, 9 \vee V$ & 7 & & \\
\hline
\end{tabular}

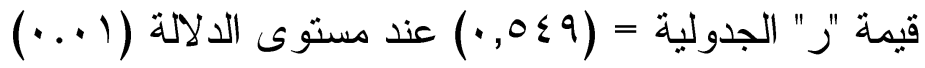

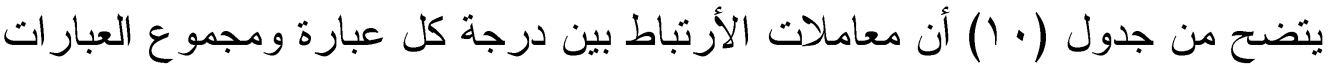

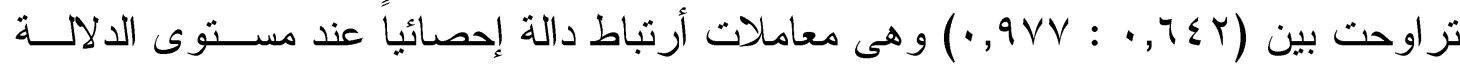

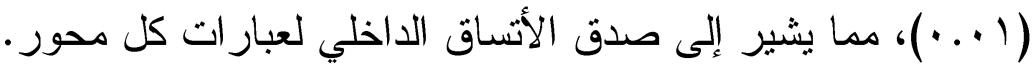

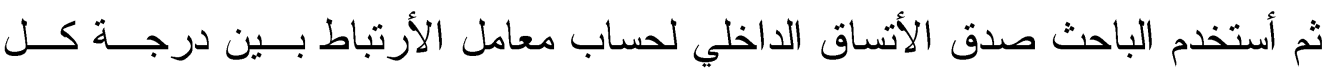

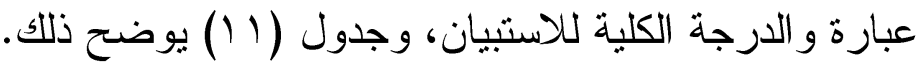
جدول (11)

معاملات الأرتباط بين درجة كل عبارة و الارجة الكلية للأستبيان (ن=• (Y)

\begin{tabular}{|c|c|c|c|c|c|c|c|}
\hline \multicolumn{2}{|c|}{ المحور الرابريم) } & \multicolumn{2}{|c|}{ 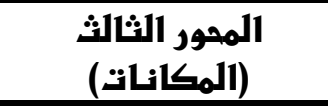 } & \multicolumn{2}{|c|}{ المدور الثانياني } & \multicolumn{2}{|c|}{ المحور الأول (المغاهيم) } \\
\hline 1الإرتباط & العبارة & 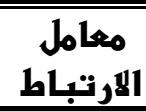 & العبارة & $\begin{array}{l}\text { 1الارتباط } \\
\text { معام }\end{array}$ & العبارة & 11 معامل & العبارة \\
\hline$\overline{* *} \cdot, \wedge 97$ & 1 & $\overline{t *}^{* *, 9,9}$ & 1 & ${ }^{* *} \cdot, 97 \mathrm{~V}$ & 1 & $* *, 971$ & 1 \\
\hline${ }^{* *} \cdot, q \leqslant \mu$ & r & ${ }^{* *} \cdot, \vee \vee 9 V$ & r & ${ }^{\star \star} \cdot, \wedge \wedge \mathrm{V}$ & r & ${ }^{* *} \cdot, 90 \mathrm{r}$ & $r$ \\
\hline${ }^{* \star} \cdot$, , 0. & $\mu$ & ${ }^{* *},, V \neg Y$ & $\mu$ & ${ }^{* *} \cdot, 100$ & r & ${ }^{* *} \cdot, q Y \mu$ & $\mu$ \\
\hline$* \star \cdot, 971$ & $\varepsilon$ & ${ }^{* *} \cdot, 97 \mathrm{~V}$ & $\varepsilon$ & ${ }^{* \star} \cdot, 97 \mathrm{~V}$ & $\varepsilon$ & ${ }^{* *} \cdot, \wedge r V$ & $\varepsilon$ \\
\hline${ }^{\star \star} \cdot, \pi \mu \varepsilon$ & 0 & $\star * *, 917$ & 0 & ${ }^{\star \star} \cdot, 9 \leqslant \mu$ & 0 & ${ }^{* *} \cdot, 9 Y Y$ & 0 \\
\hline$* *, 9 \ldots$ & 7 & & & ${ }^{* \star} \cdot, 97 \mathrm{~V}$ & 7 & & \\
\hline
\end{tabular}

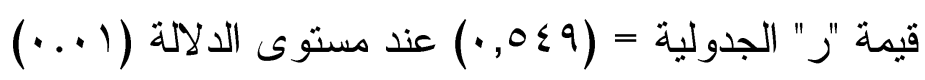

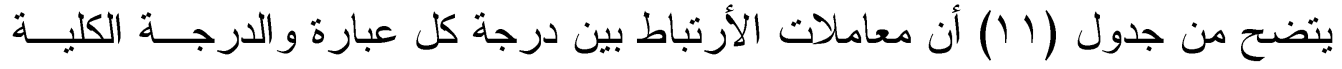

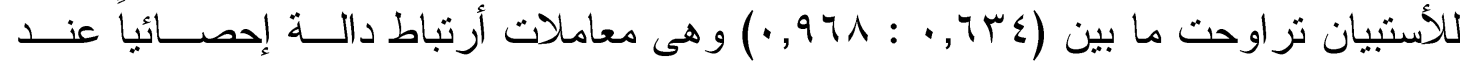
مستوى الدلالة (1 ...)، مما يشير إلى صدق الأتساق الداخلي لعبار ات الأستبيان ككل. 
ثم قام الباحث بحساب معامل صدق الأتساق الداخلي بين درجة كل محور و الدرجــة

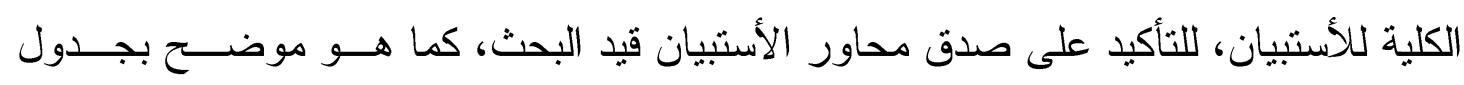

$$
\text { جدول (r) }
$$

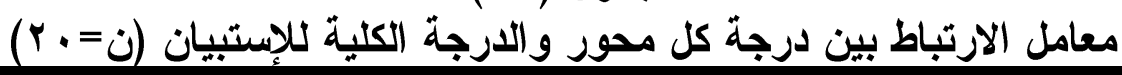

\begin{tabular}{|c|c|c|c|}
\hline معامل الارتباط & عدد العبارات & المحاور & مـ \\
\hline${ }^{* \star} \cdot, 9 \wedge 4$ & 0 & الكفاهيخ & 1 \\
\hline **.,99Y & 7 & التخطيط & $\begin{array}{r}r \\
\end{array}$ \\
\hline${ }^{* \star} \cdot, 971$ & 0 & الامكانات & $r$ \\
\hline$* * ., 914$ & 7 & التنظيم & $\varepsilon$ \\
\hline \multicolumn{2}{|c|}{ r reبارة } & \multicolumn{2}{|c|}{ مجموع العبار ات } \\
\hline
\end{tabular}

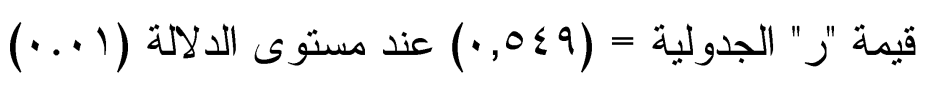

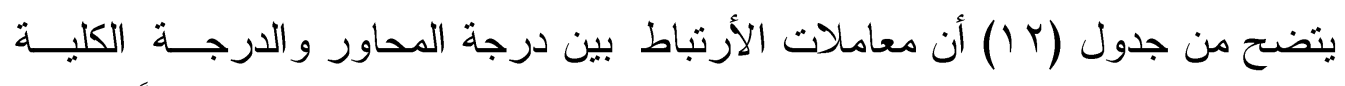

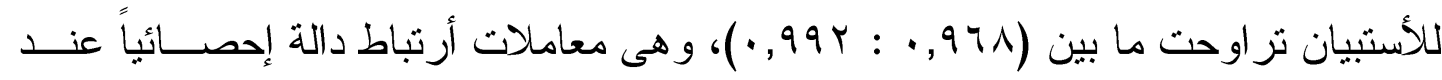
مستوى (1 +..)، مما يشير إلى الاتساق الداخلي للأستبيان ككل. ب- الثبات :

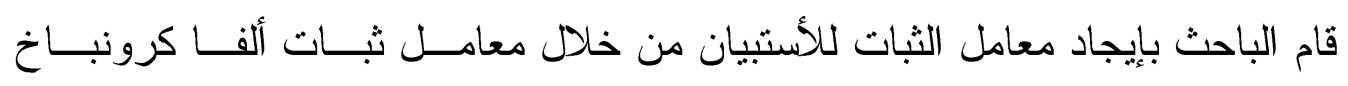

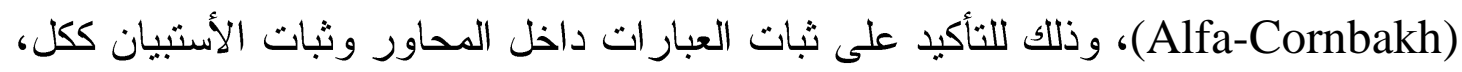

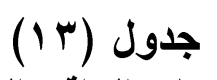$$
\text { كما هو موضح بجدول (T) (1). }
$$

\begin{tabular}{|c|c|c|c|}
\hline معامل ثبات ألفا كرو نباخ & عدد العبارات & المحـــــور & م \\
\hline., $97 \varepsilon$ & 0 & الدفاهيم & 1 \\
\hline., $9 \vee \mu$ & 7 & التخطيط & $r$ \\
\hline$\cdot, 949$ & 1 & الأمكانات & r \\
\hline$\cdot, \Lambda \mu \mathrm{V}$ & 0 & 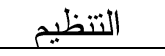 & $\varepsilon$ \\
\hline$\cdot, 9 \wedge \varepsilon$ & rr & ل ل ل لمجموع & \\
\hline
\end{tabular}

معامل ثبات ألفا كرونباخ لمحاور استبيان الواقع الحالي لأداء المنشأت الرياضية بجامعة

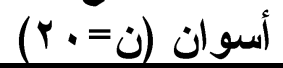

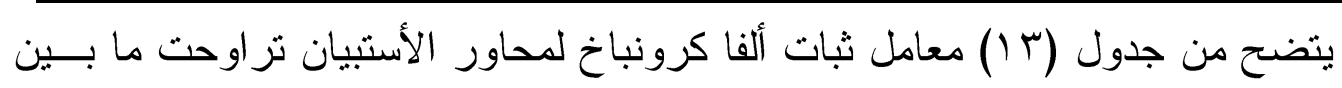
(

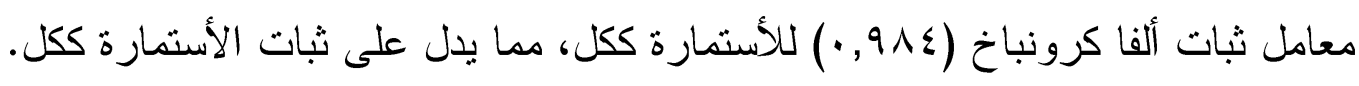


- تطبيق الأستبيان في صورته النهائية:

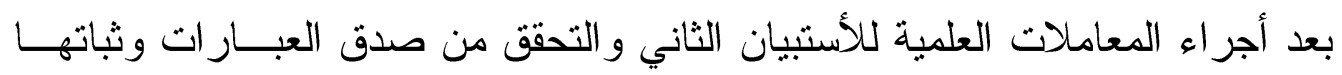

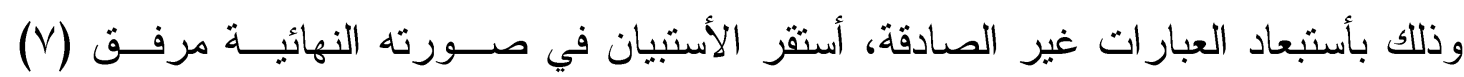

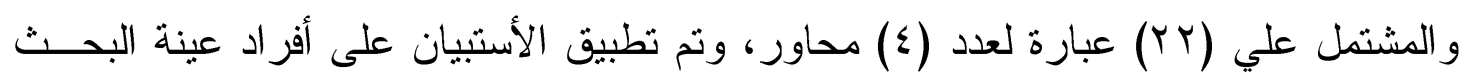

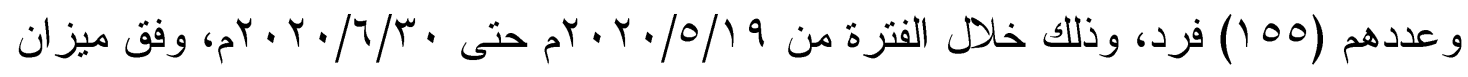

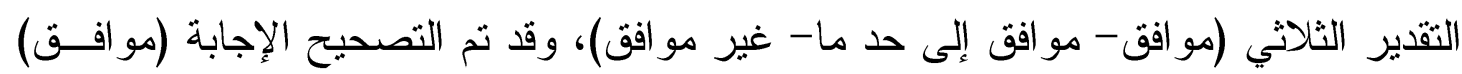

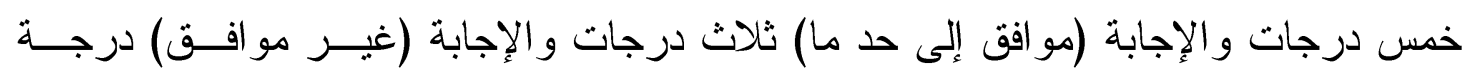

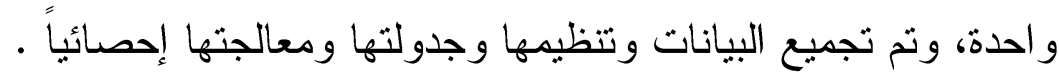

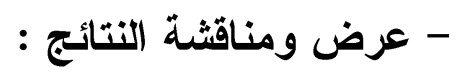

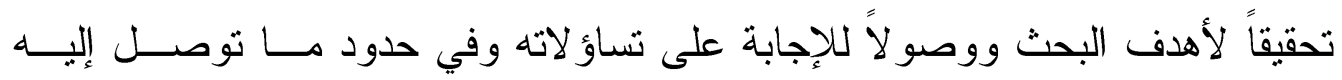

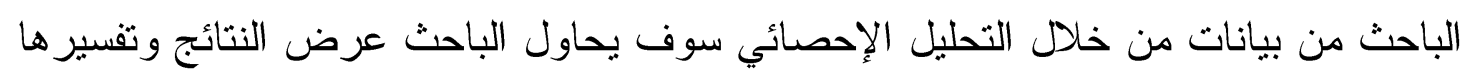
ومناقشتها. ا - الإجابة على التساؤل الأول: ما الواقع الحالي لخطــ الأســثتمـار الرياضـــي للمنشــأت

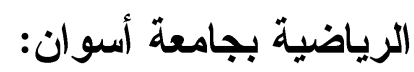

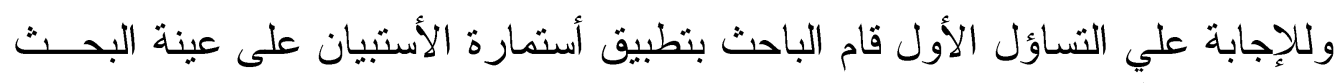

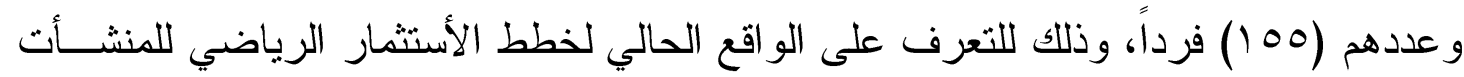

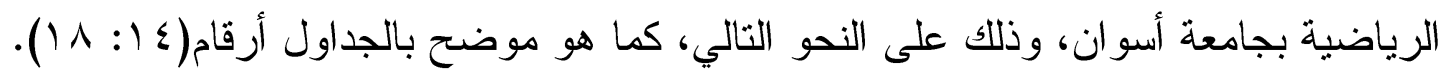

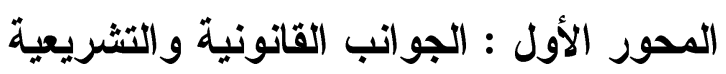

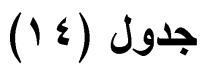

الارجة المقدرة والنسبة المئوية لأستجابات عينة البحث في المحور الأول الجوانب القانونية

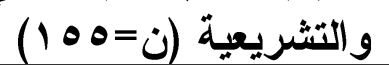

\begin{tabular}{|c|c|c|c|}
\hline المئوية & المقدرة & العبـــــارات & م \\
\hline$\% \leqslant \Lambda .7 \leqslant$ & rVV & توجد قو انين ولو ائح خاصة نتجع على أستثمار المنشات الرياضية بالجامعة . & 1 \\
\hline$\% \circ \mu$ r.r & «11 & توجد تشهيلات تثجع المستثمرين على الأستثمار في المنشات الرياضية بالجامعة. & r \\
\hline$\% \circ Y . V V$ & $\varepsilon \cdot 9$ & توجد لو ائح تتظم العمل الأستثماري بالمنشات الرياضية بالجامعة. & r \\
\hline$\% 01.97$ & $\sum 0 \mathrm{~V}$ & توجد قرار ات وزارية تتيح أستثمار المنشات الرياضية بالجامعة . & $\varepsilon$ \\
\hline$\% ч \varepsilon .9$. & $0 . \mu$ & يوجد نص تشريعى في اللو ائح المنظمة للجامعة لعمل المنشات الرياضية. & 0 \\
\hline$\% \pi r . .9$ & $\varepsilon \wedge 9$ & توجد صيغة عقود مبرمة و اضحة تضمن حق المستثر و المنشأة. & 7 \\
\hline$\% 07.9$. & rTIT & & مجه \\
\hline
\end{tabular}


يتضح من جدول (ع () أن النسبة المئوية لأستجابات عينة البحث في عبار ات المحور

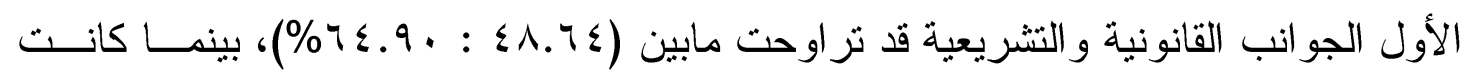
النسبة المئوية لمجموع المحور ( .9.907\%).

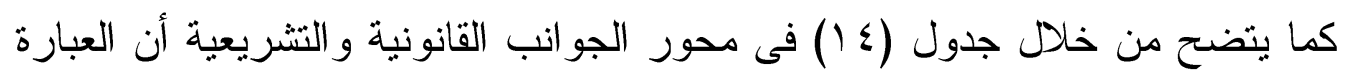

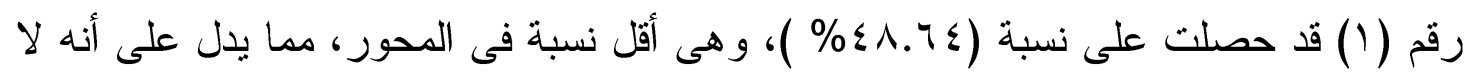

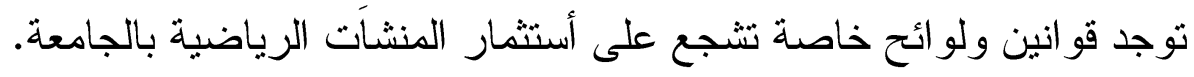

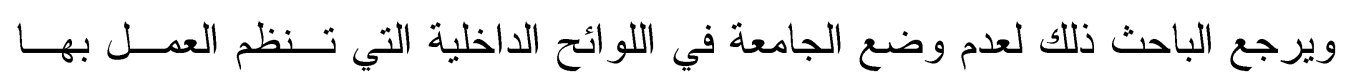

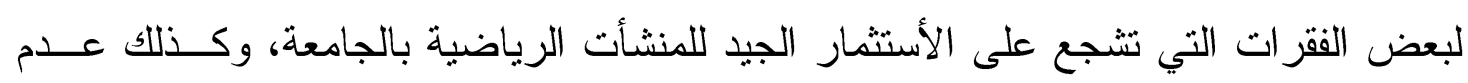

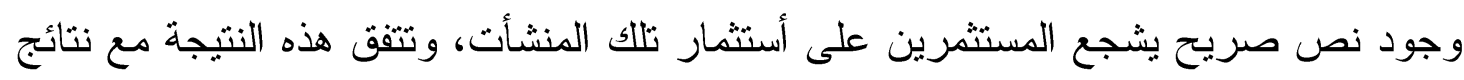

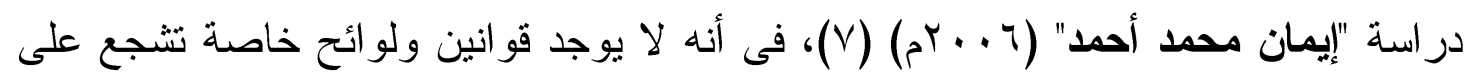

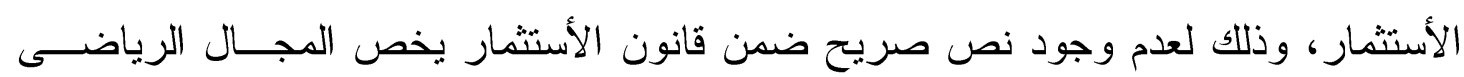

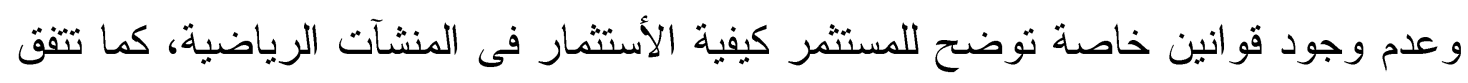

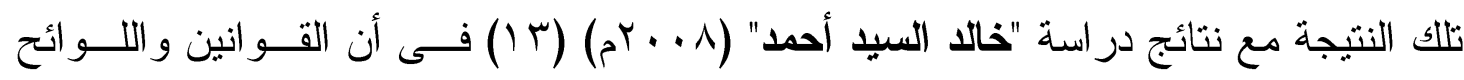

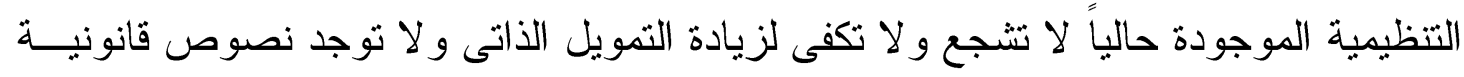
تحكم طبيعة العلاقة بين المستثمر و المنشأة.

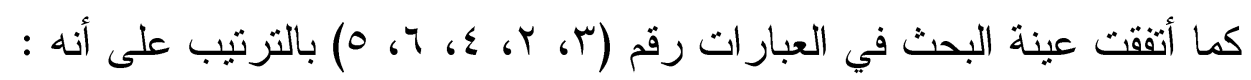

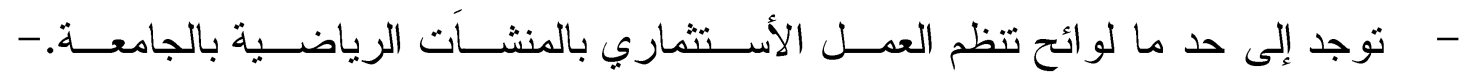

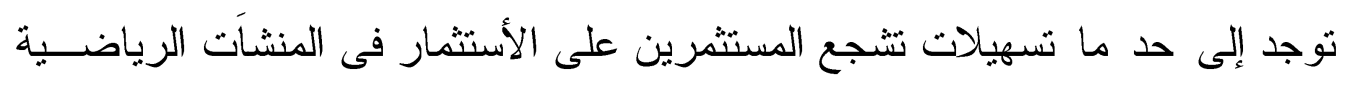

\section{بالجامعة.}

- توجد إلى حد ما قرار ت توات وزارية تتيح أستثمار المنشآت الرياضية بالجامعة.

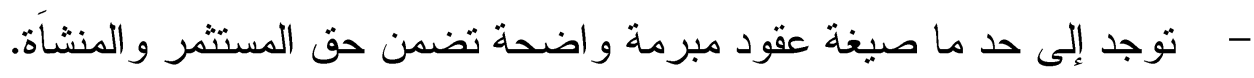

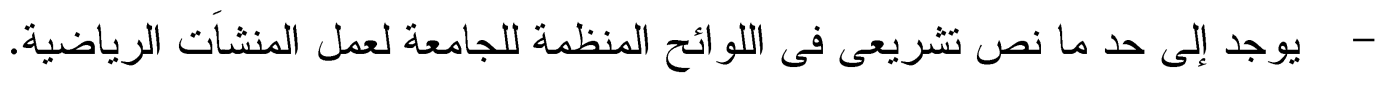

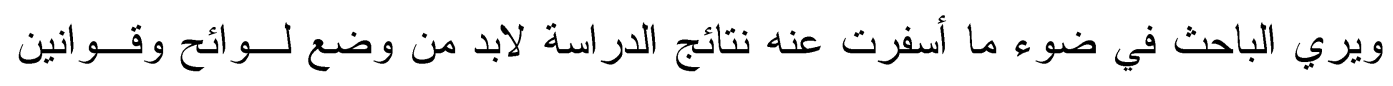

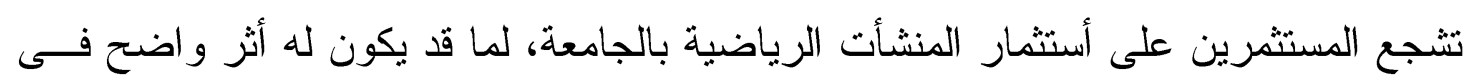

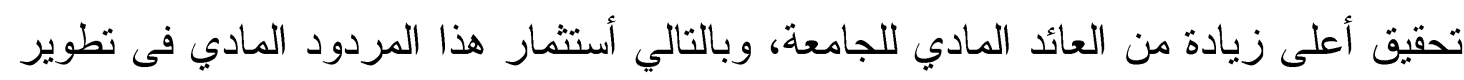

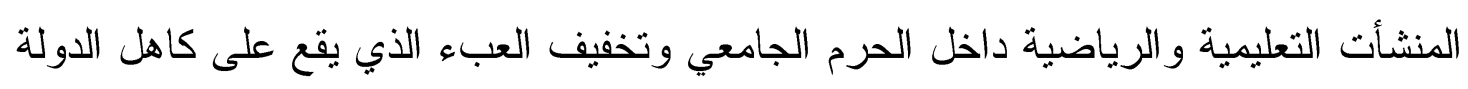

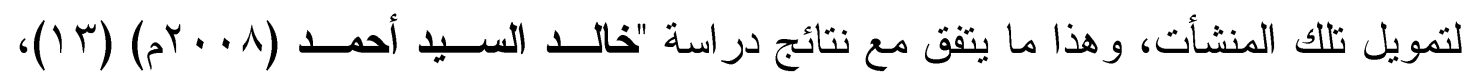

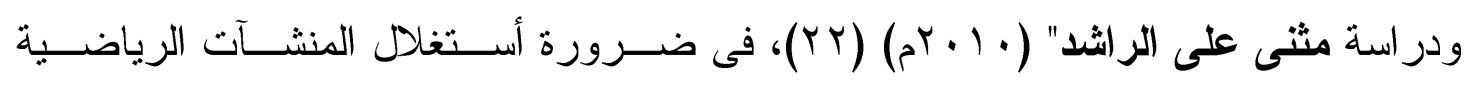


و أستثمار ها لتحقيق أعلى عائد من التمويل الذاتى بها وتشجيع المستثمرين وعمل التســـيلات

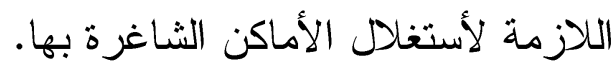
المحور الثاني: الجوانب الإدارية

\section{جدول (10)}

الدرجة المقدرة والنسبة المئوية لأستجابات عينة البحث في المحور الثاني الجواتب الإدارية (100=0 (ن)

\begin{tabular}{|c|c|c|c|}
\hline النسبة المئوية & الدرجة المقدرة & العبــــارات & م \\
\hline$\% \leqslant \uparrow . \wedge r$ & זוז & توجد إدارة متخصصة خاصة بالاستثمار داخل الجامعة. & 1 \\
\hline$\% \vee r .17$ & $07 \mathrm{~V}$ & هناك أهتمام من قبل إدارة الجامعة لأستثمار المنشأت الرياضية. & r \\
\hline$\%$ \%.V. & rra & توجد تسهيلات فى الإجر اءات الإدارية الخاصة بالمستثمر. & r \\
\hline$\% 01 . r Y$ & rqv & نوجد خطة أستثمارية بالجامعة نوضح المجالات التي يمكن الأستثمار فيها بالمنشأت الرياضية. & $\varepsilon$ \\
\hline$\% 00 . \wedge \mathrm{V}$ & זسז & تعد الإجر اءات الإدارية من المعوقات التى تواجه الأستثمار بالمنشأت الرياضية. & 。 \\
\hline$\% 0 \varepsilon .01$ & $\leq r r$ & توجد معرفة من قبل المستثرين بالخطو ات اللازمة بكيفية الاستثمار بالمنثأت الرياضية بالجامعة. & 1 \\
\hline$\% \pi 1$ & orv & توجد صعوبة فى التعامل بين المستثمر و القائمين على إدارة المنشأت الرياضية. & $\mathrm{v}$ \\
\hline$\% \bullet १ . v \vee$ & $r r \leqslant r$ & وع المحور & \\
\hline
\end{tabular}

يتضح من جدول (10) أن النسبة المئوية لأستجابات عينة البحث في عبار ات المحور

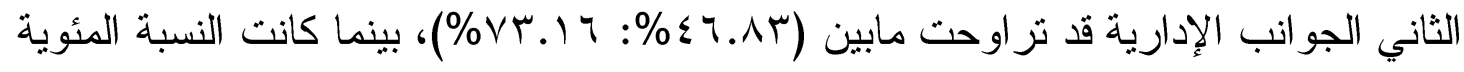
لمجموع المحور (1\%).VV)

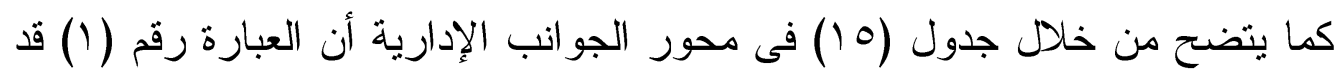

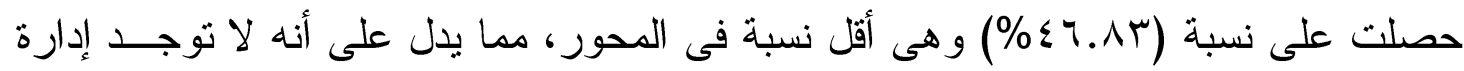
متخصصة خاصة بالأستثمار داخل الجامعة.

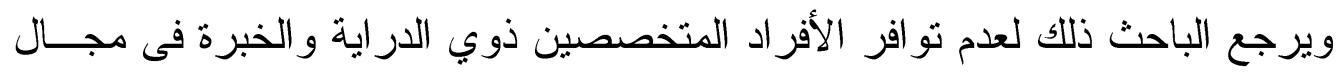

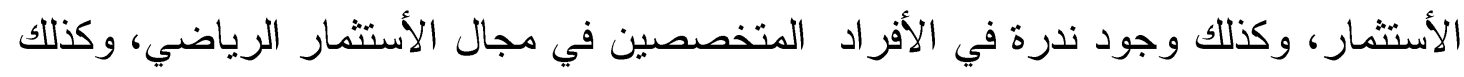

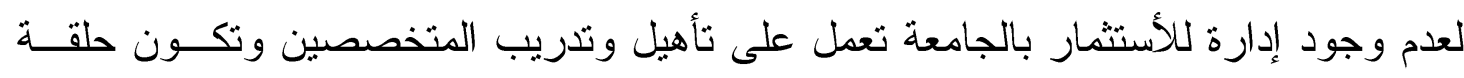

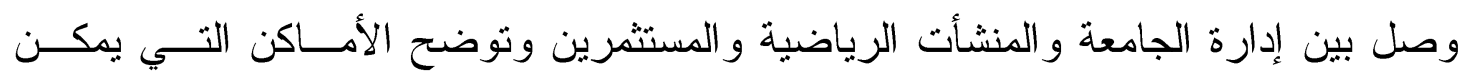

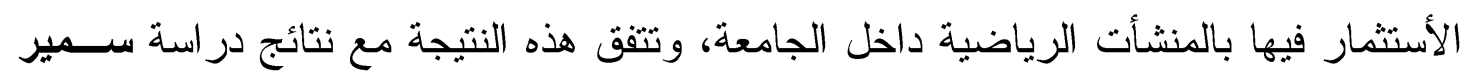

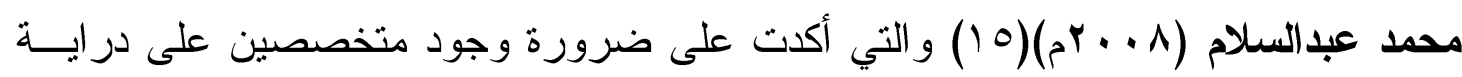

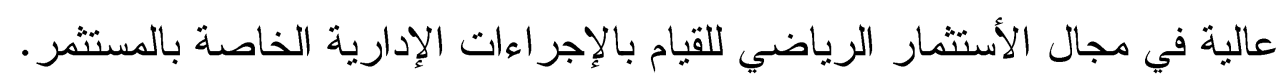

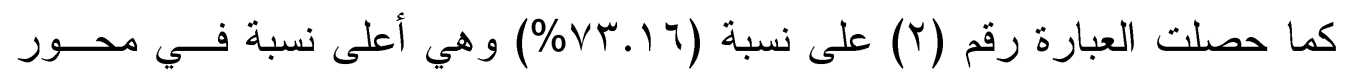

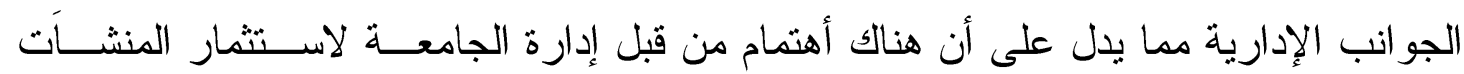
الرياضية بالجامعة. 
ويرجع الباحث ذلك أن إدارة الجامعة لديها أهنمام كبير لخلق مناخ جيــــ للمســتفيدين

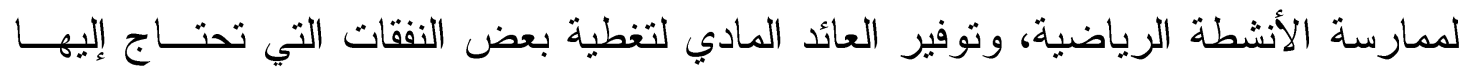

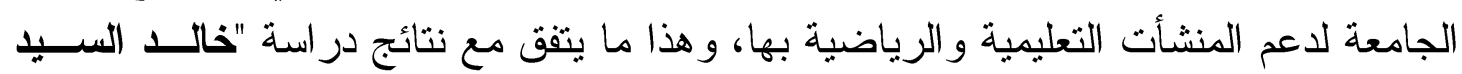

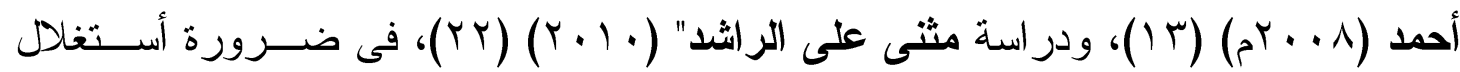
المنشآت الرياضية وأستثمار ها لتحقيق أعلى عائد من التمويل الذاتى بها ولى التها وتشجيع المستثمرين

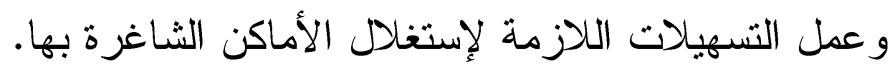

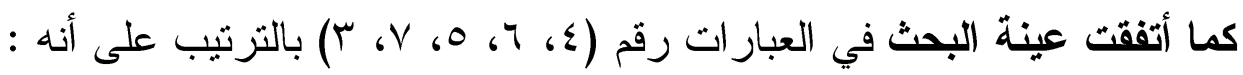

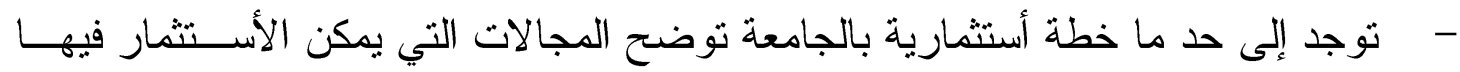
بالمنشاًت الرياضية.

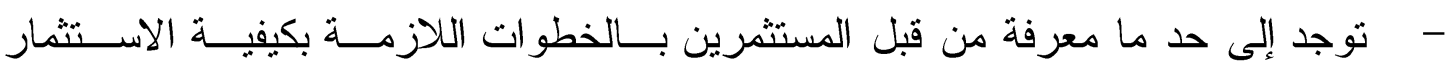
بالمنشأت الرياضية بالجامعة.

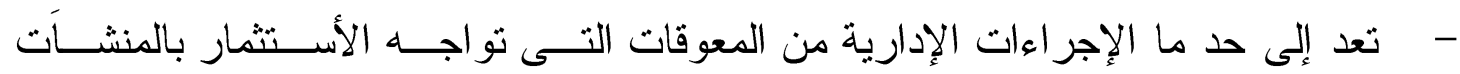
الرياضية.

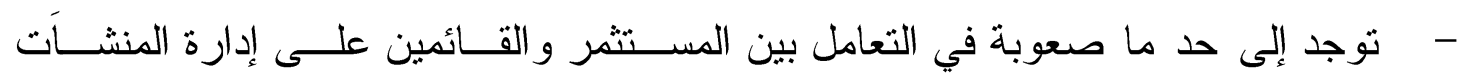
الرياضية. - توجد إلى حد ما تسهيلات فى الإجر اءات الإدارية الخاصة بالمستثمر .

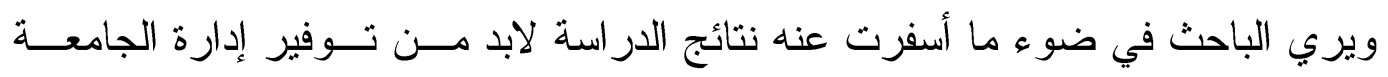

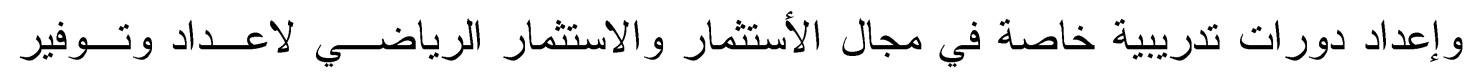

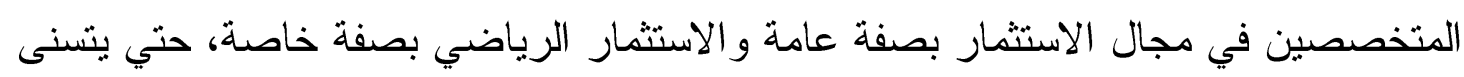

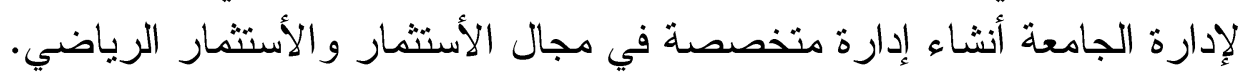
المحور الثالث : الجوانب القتية

جدول (17)

الارجة المقدرة والنسبة المئوية لأستجابات عينة البحث في المحور الثالث الجوانب الفنية $(100=\dot{0})$

\begin{tabular}{|c|c|c|c|}
\hline النئوية & 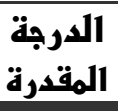 & العبـــــارات & م \\
\hline$\% \vee \vee . \wedge$. & $\overline{T H}$ & توجد ندرة في المتخصصين بمجال الأستثمار الرياضى بالجامعة. & 1 \\
\hline$\%$ \%r.Ir & 009 & هناك ضعف في المستوى الفنى للعاملين بالمنشات الرياضية بالجامعة . & r \\
\hline$\% \circ$ or.VY & $\varepsilon .9$ & نو الأسنثمار. خبرة علمية وعملية لدى القائمين على العمل بالمنشات الرياضية فى مجال & r \\
\hline$\% 70.17$ & 0.0 & هناك تتبؤ بأن العائد المادى لأستثمار المنشات الرياضة بالجامعة غير مجزي . & $\varepsilon$ \\
\hline$\%$ \%.r. & $\varepsilon \wedge 0$ & توجد أفكار مطبقة يمكن الاستفادة منها في الاستثمار الرياضى بالجامعة . & 0 \\
\hline$\% 77.99$ & roTl & ع المحو & \\
\hline
\end{tabular}


يتضح من جدول (T (1) أن النسبة المئوية لأستجابات عينة البحث في عبار ات المحور

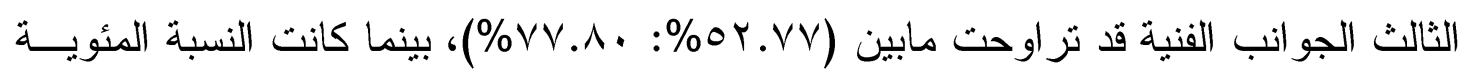
لمجموع المحور (9.97\%\%).

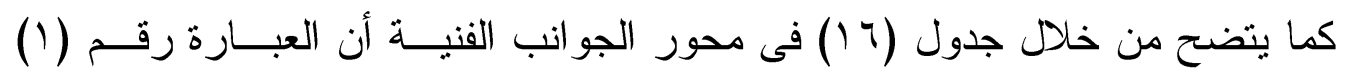

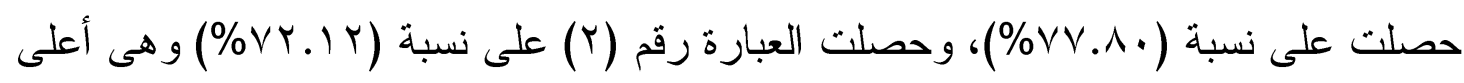

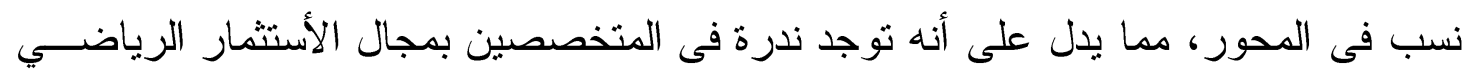

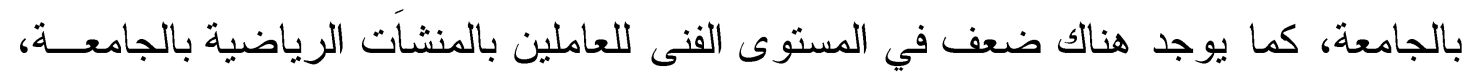

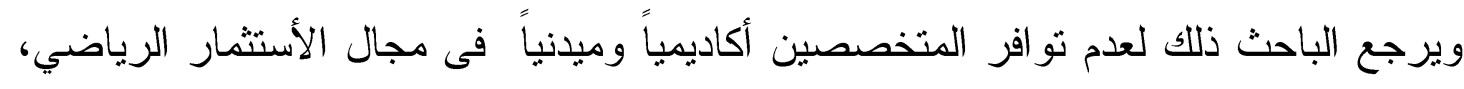

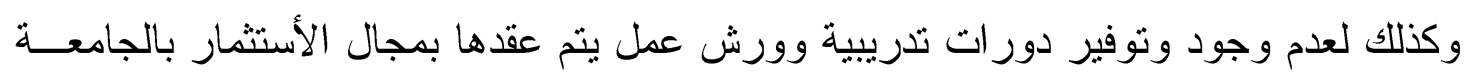

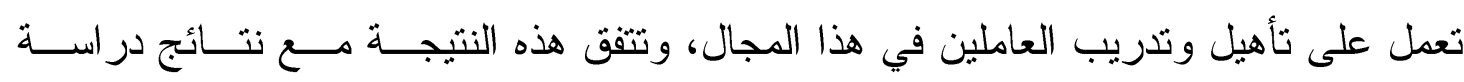

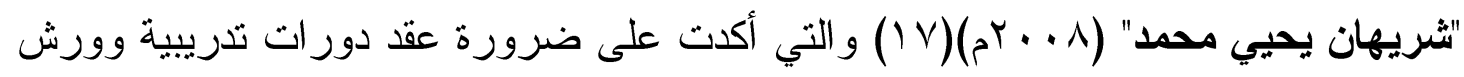

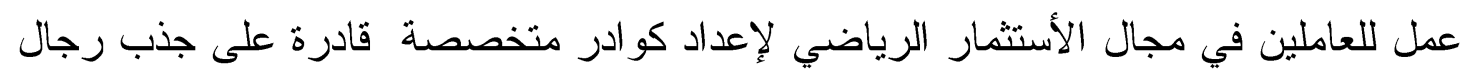

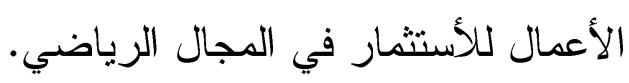

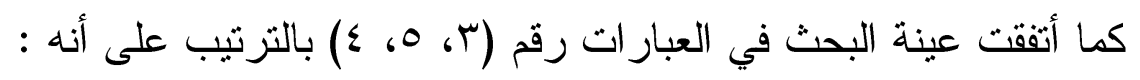

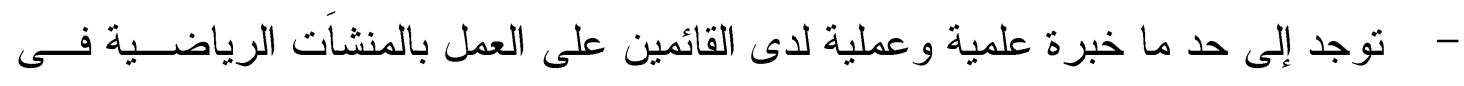
مجال الأستثمار .

- - توجد إلى حد ما أفكار مطبقة يمكن الأستفادة منها فى الأستثمار الرياضى بالجامعة.

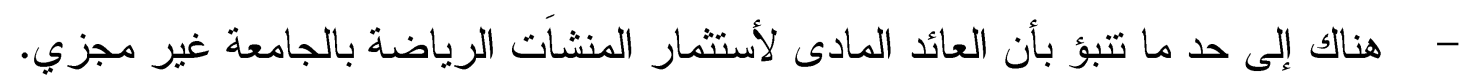

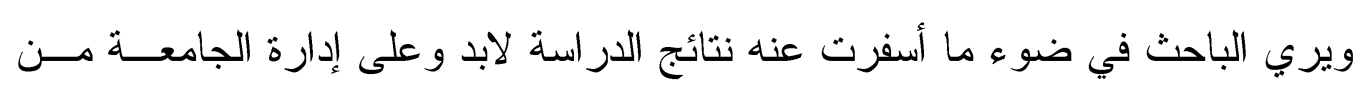

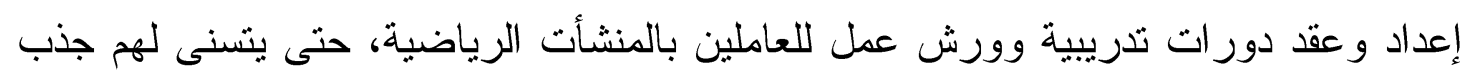

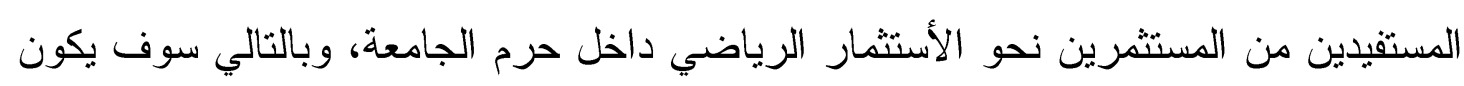

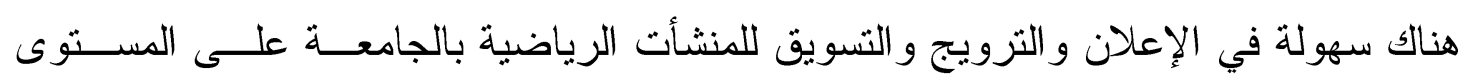
المجتمعي.

\section{مجلة أسيوط لعلوم وفنوز التربية الرياضية}


المحور الرابع : جواتب الوعي بالاستثمار الرياضي

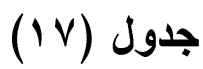

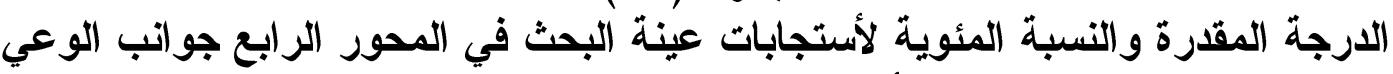

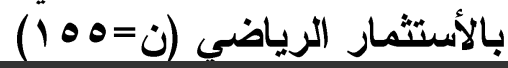

\begin{tabular}{|c|c|c|c|}
\hline النئوية & المقدرةة & العبــــــارات & م \\
\hline$\% \vee 0 . \leqslant \Lambda$ & 010 & يوجنداري. وعى كافي لدي إدارة الجامعة و العاملين بأن المنشات الرياضية تعتبر مجال & 1 \\
\hline$\% \vee I . \wedge V$ & $00 \mathrm{~V}$ & 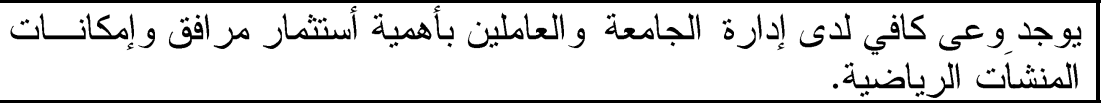 & $r$ \\
\hline$\% \vee \vee . \wedge$. & 7.4 & و والمجتمع. وعى بالدور الذى تلعبه المنشأت الرياضية بالجامعــة فــى تتميــة الفــرد & r \\
\hline \%VT.Yo & 091 & 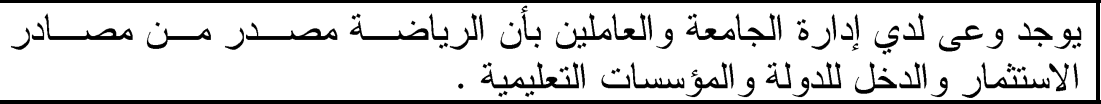 & $\varepsilon$ \\
\hline \% • . r & $0 \leqslant 0$ & 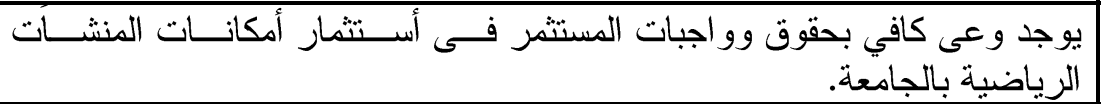 & 0 \\
\hline$\% \vee \varepsilon . \Gamma \varepsilon$ & $r \wedge \wedge 1$ & مجموع المحور & \\
\hline
\end{tabular}

يتضح من جدول (VV) أن النسبة المئوية لأستجابات عينة البحث في عبار ات المحور

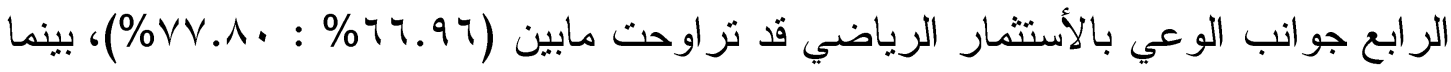

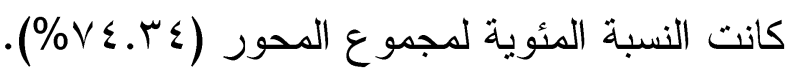

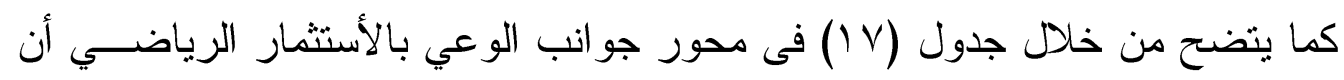

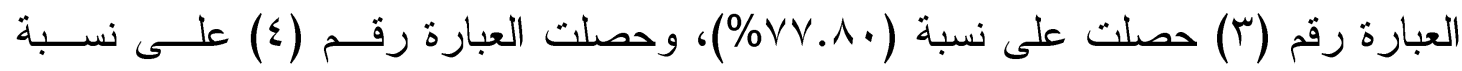

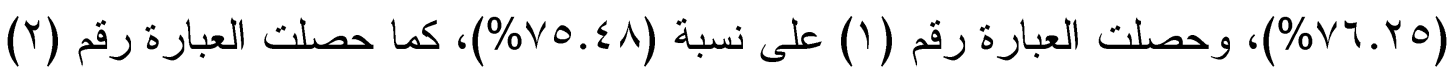

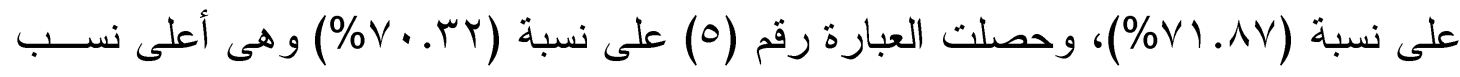

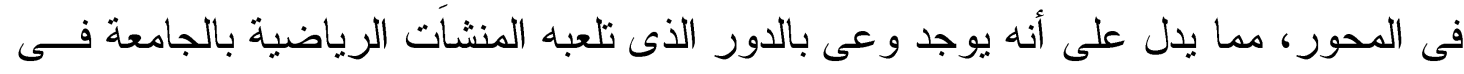

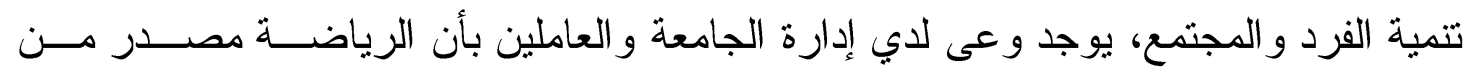

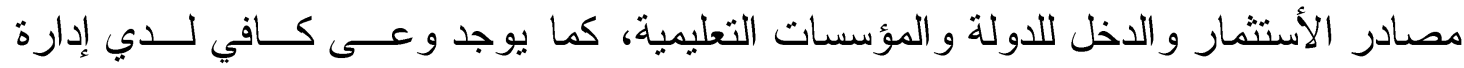

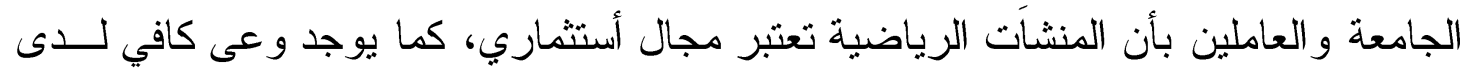

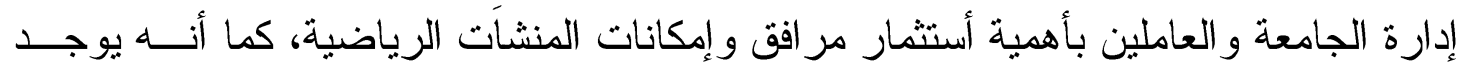
وعى كافي بحقوق وواجبات المستثمر فى أستثمار أمكانات المنشأت الرياضية بالجامعة.

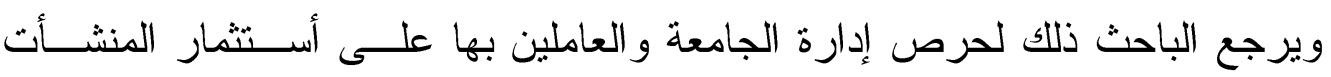

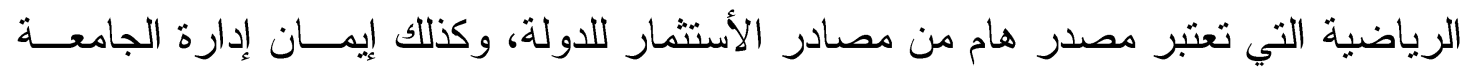

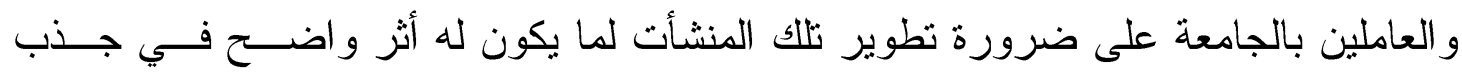
مجلة أسيوط لعلوم وفنون التربية الرياضية 
رؤوس أموال المستثمرين داخل الحرم الجامعي، وتتقق هذه النتيجة مع نتائج در اسة عطيــه

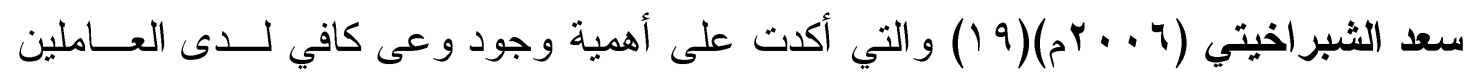
بالأندية الرياضية بأهمية الأستثمار في مجال كرة القدم بتلك الأندية لتغطية النفقات الذاتية لها. ويري الباحث في ضوء ما أسفرت عنه نتائج الدراسة لابد و على إدارة الجامعة إعداد

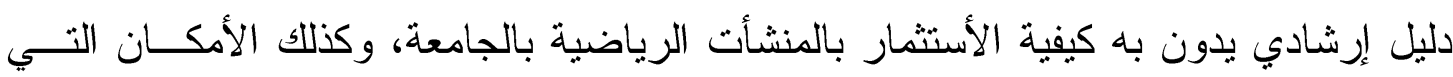

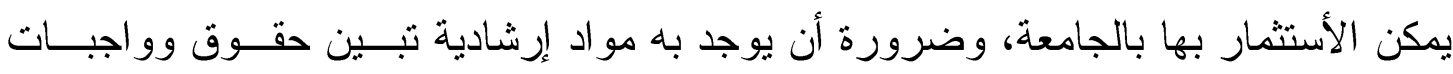
المستثرين بالمنشأث الرياضية.

المحور الخامس : جوانب الوعى بالسياسة الرياضية جدول (1^)

الدرجة المقدرة والنسبة المئوية لأستجابات عينة البحث في المحور الخامس جوانب الوعي

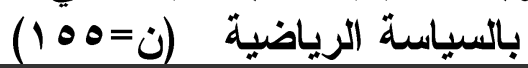

\begin{tabular}{|c|c|c|c|}
\hline النئوبة & الدقدرة & العبــــارات & م \\
\hline$\% 0 \wedge . \leqslant 0$ & sor & التوجد سياسة و اضحة لاستثمار المنشات الرياضية بالجامعة. & 1 \\
\hline$\% \vee \cdot .0 \Lambda$ & $0 \leqslant V$ & لمنل المجالات الأخترى من إدارة الجامعة بأستثمار المنشات الرياضية من الناحية الأقتصــادية & r \\
\hline$\% 01.97$ & ¿०V & بالجامعة. توباسة استثمارية مفعلة لأستثمار إمكانــات ومر افـق المنشــات الرياضــية & r \\
\hline$\%$ \%.น人 & $\sum 99$ & ليوجد هدف و اضح لاستثمار المنشات الرياضية من قبل إدارة الجامعة . . & $\varepsilon$ \\
\hline$\% 07.9$. & $\leqslant \leqslant 1$ & |توجد عرقلة للمستثرين تعوق تحقيق عائد كبير من جذب رؤوس الأمو ال للمنشات & 0 \\
\hline$\% 71 . \wedge 0$ & rrqV & تمبو ع المحور & \\
\hline
\end{tabular}

يتضح من جدول (1 ا) أن النسبة المئوية لأستجابات عينة البحث في عبار ات المحور

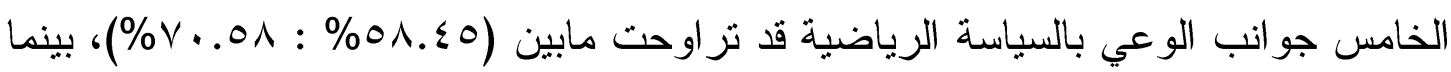

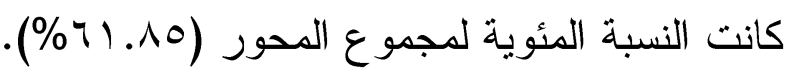

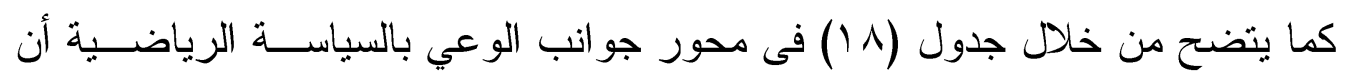

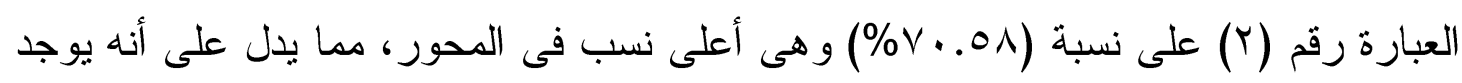

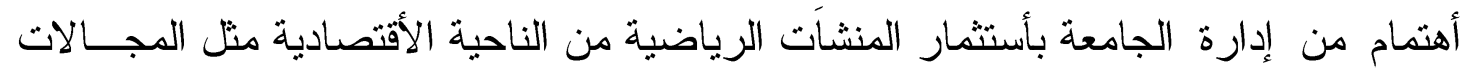
الأخرى الهن.

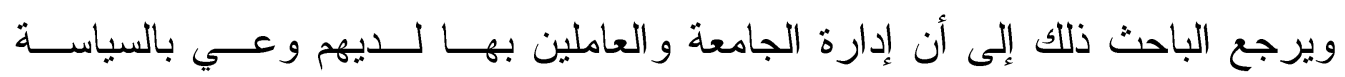
الرياضية، ولديهح هدف و اضح في تعزيز التمويل الذاتي لموارد الجامعة من خلال أســتثمار

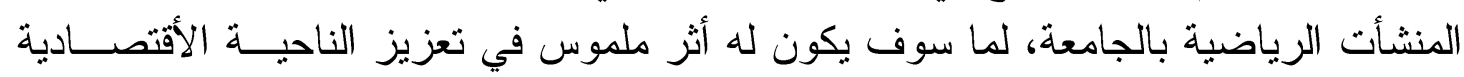


للجامعة من العائد المتوقع من مردود تلك المنشأت، و هذا ما يتفق مع در اسة أشرف محمــود

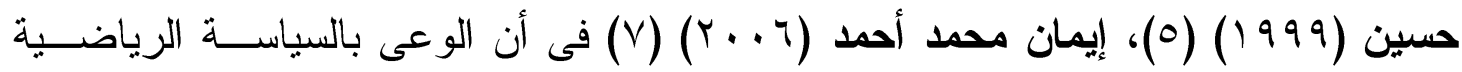
يساعد المنشآت الرياضية على الأستثمار الأمثل فى تحقيق الموارد الذاتية التى فى حاجة مانى ماسة إليها الدولة فى ظل الظروف الإقتصادية التى تعيشها مصر الأن.

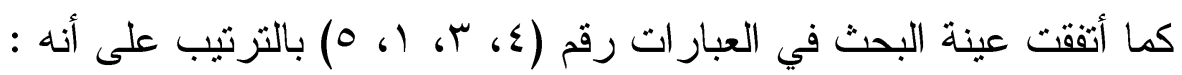
- - يوجد إلى حد ما هدف و اضح لاستثمار المنشات الرياضية من قبل إدارة الجامعة .

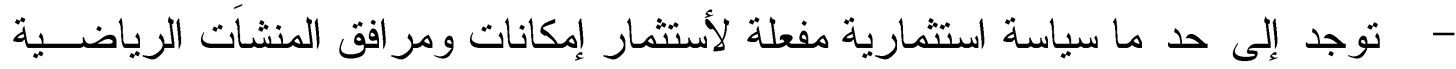
بالجامعة. - - توجد إلى حد ما سياسة و اضحة لاستثمار المنشاًت الرياضية بالجامعة.

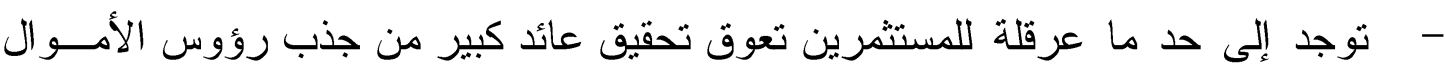
للمنشآت الرياضية بالجامعة. ويري الباحث في ضوء ما أسفرت عنه نتائج الدراسة لابد من العمل على تفعيل السياسة

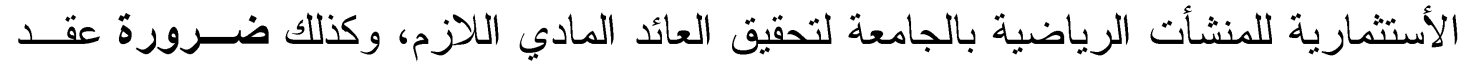
دور ات تدريبية للعاملين بالمنشأت الرياضية بالجامعة في كيفية التعامل مع المستثرين.

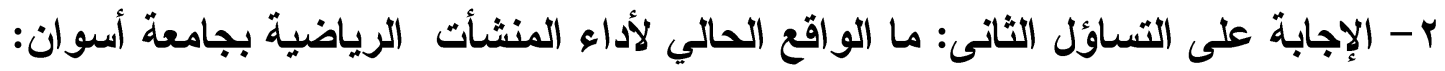
وللإجابة علي التساؤل الثاني قام الباحث بتطبيق أستمارة الأستبيان على عينة البحث

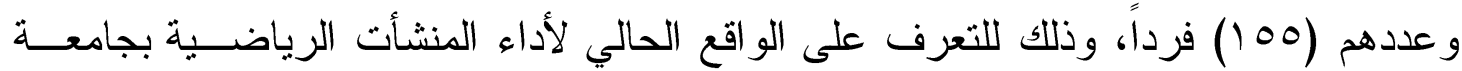
أسوان، وذلك على النحو التالي، كما هو موضح بالجداول أرقام (9 (1 : ب r):

جدول (19) المحور الأول : المفاهيم: المدئ

الارجة المقدرة والنسبة المئوية لأستجابات عينة البحث في المحور الأول المفاهيم (100=ن)

\begin{tabular}{|c|c|c|c|}
\hline المئويةبة & الدقدرة & العبـــــارات & م \\
\hline$\% \vee 7 . \vee V$ & 090 & يوجد أهتمام من قبل إدارة الجامعة للحفاظ على المنشأت الرياضية. & 1 \\
\hline \%VY. . & 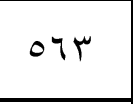 & لرياضي صي ولدي. إدارة الجامعة و العاملين بأهمية المنشات الرياضية في خلق مجتمع & r \\
\hline$\% \succ \leq .7 \leq$ & 0.1 & يوجد تقدير من إدارة الجامعة لدور مدير المنشات الرياضية بالجامعة. & r \\
\hline \%VY.IY & 009 & 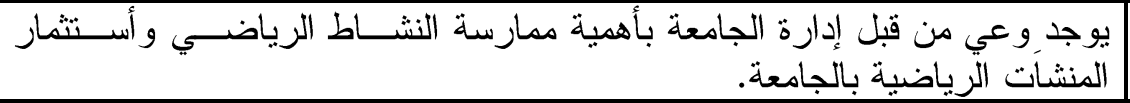 & $\varepsilon$ \\
\hline$\% \circ$ \%.А. & $\varepsilon \backslash V$ & 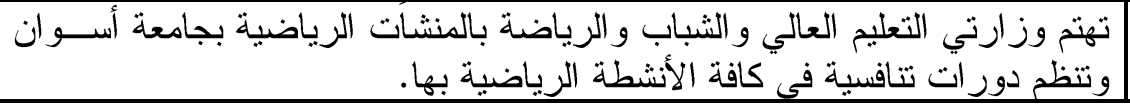 & 0 \\
\hline$\% 4 \wedge$ & TrMo & مجمو ع المحور & \\
\hline
\end{tabular}


يتضح من جدول (9 1 ) أن النسبة المئوية لأستجابات عينة البحث في عبار ات المحور

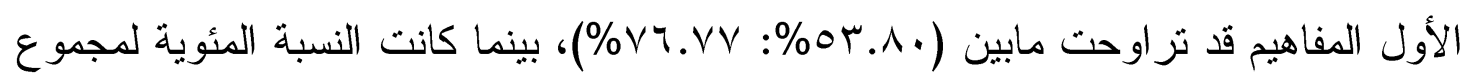

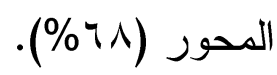

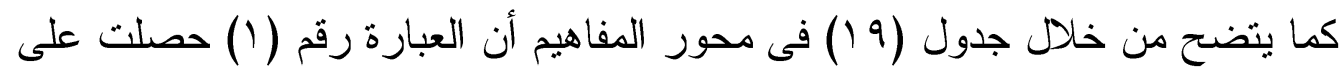

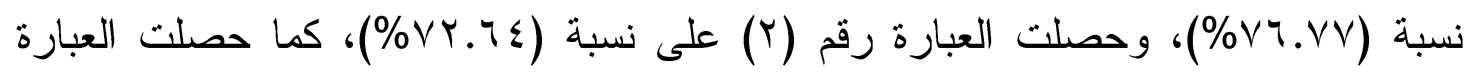

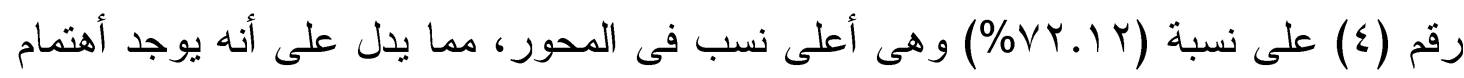

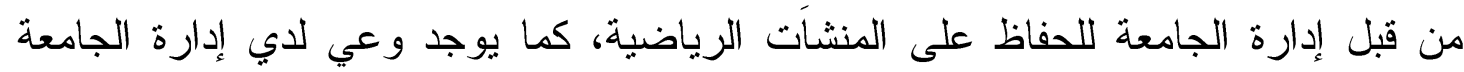

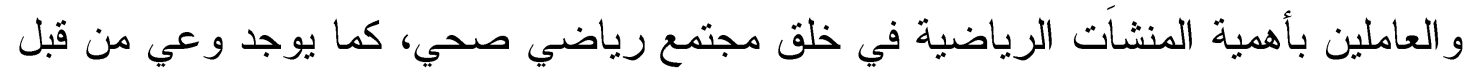

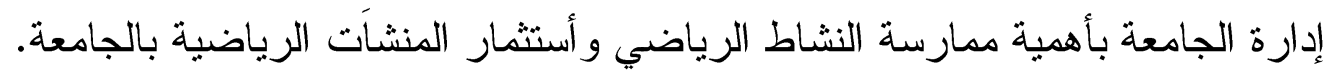

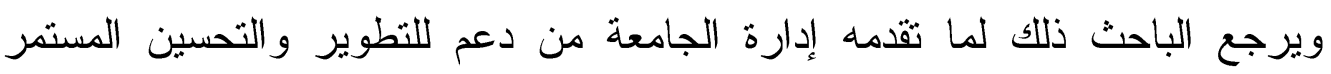
للمنشأت الرياضية داخل الجامعة، حتى تكون مصدر لجذب المستفيدين الداخليين والخارجيين وتكون مقصد للأستثمار الحقيقي للمستثرين، وكذلك حرص إدارة الجامعة وو عيها بما تقدمه

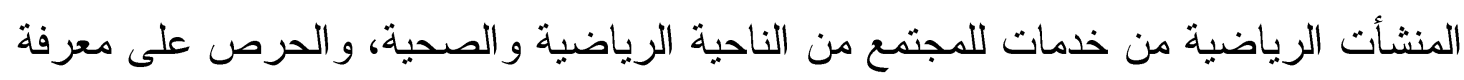

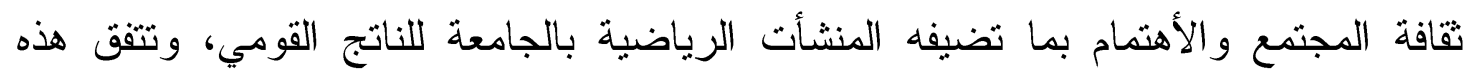

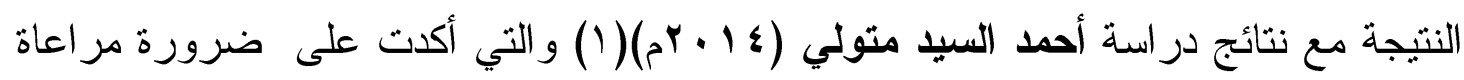

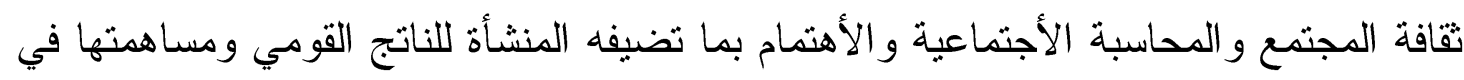

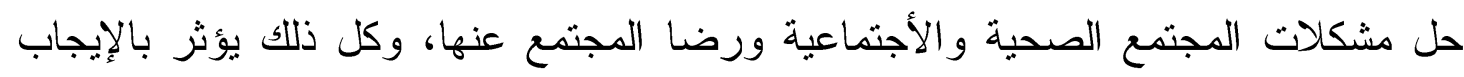
على أستمر ارية المنشأة.

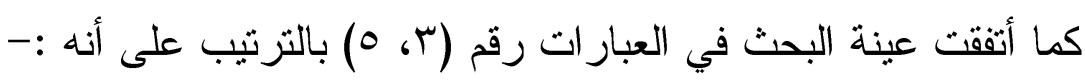

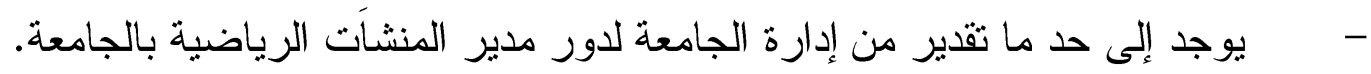

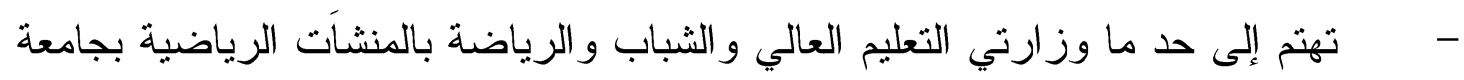

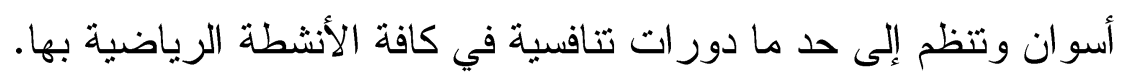

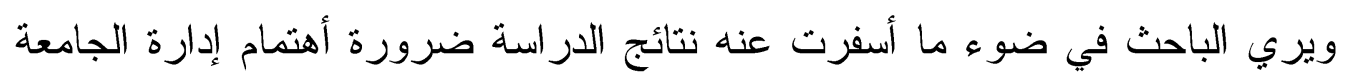

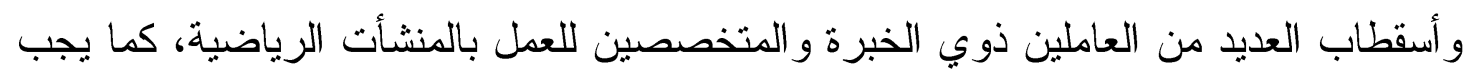

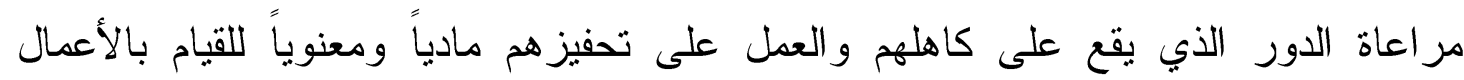

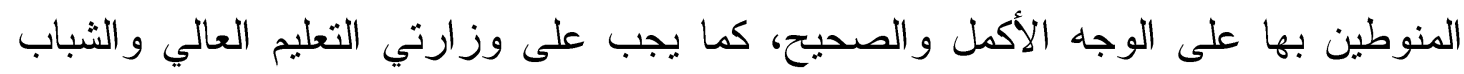

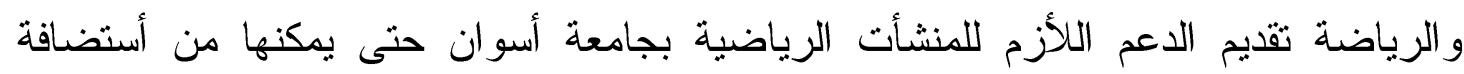

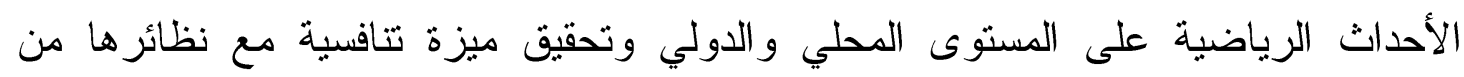

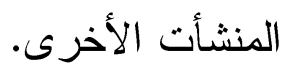


المحور الثاني : التخطيط

جدول (r) جابنة

الارجة المقدرة والنسبة المئوية لأستجابات عينة البحث في المحور الثاني التخطيط

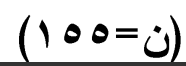

\begin{tabular}{|c|c|c|c|}
\hline المئوية & الدقروة & العبـــــارات & م \\
\hline$\% \leqslant 9.17$ & "N। & توجد إدارة خاصة بالمنشات الرياضية بالجامعة. & 1 \\
\hline$\% 0$ \%.oz & $\$ 10$ & يوجد قسم خاص بالتخطيط للمنشات الرياضية بالجامعة. & $r$ \\
\hline$\% 07 . \mathrm{\mu}$ & $\varepsilon r V$ & توضع خطط لتدريب العاملين بالمنشات الرياضية. & $\mu$ \\
\hline$\% 79.0 \leq$ & org & مشاركة العاملين في عملية التخطيط يساعد على التنفيذ الجيد للخطط . & $\varepsilon$ \\
\hline \%tr.ru & $\varepsilon \wedge \mu$ & البر امج الزمنية النى توضع داخل المنشات الرياضية تكون قابلة للتعديل. & 0 \\
\hline$\% 00 . .9$ & $\varepsilon r V$ & بالجامعحة بر امج زمنية سنوية لجميع الأنشطة الرياضية التي تقام بالمنشات الرياضية & 7 \\
\hline$\% 0 \mathrm{~V} .7 \mathrm{~V}$ & rฯ人 & 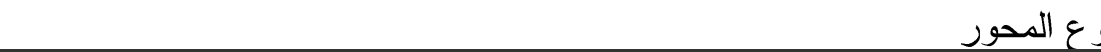 & \\
\hline
\end{tabular}

يتضح من جدول (·r) أن النسبة المئوية لأستجابات عينة البحث في عبار ات المحور

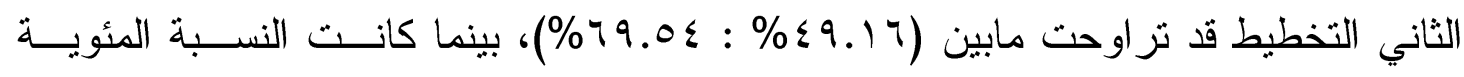

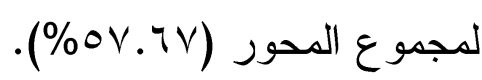

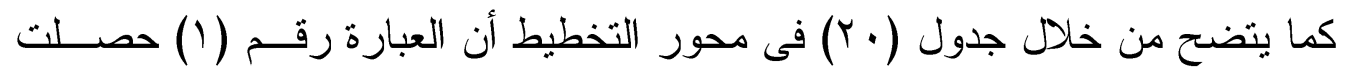

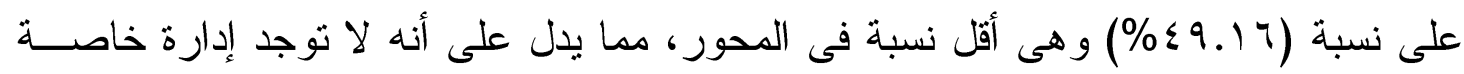
بالمنشاَت الرياضية بالجامعة.

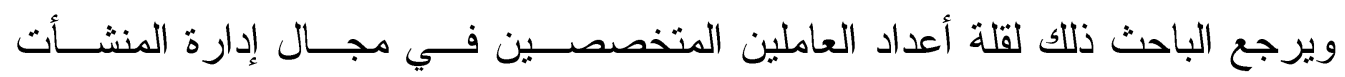

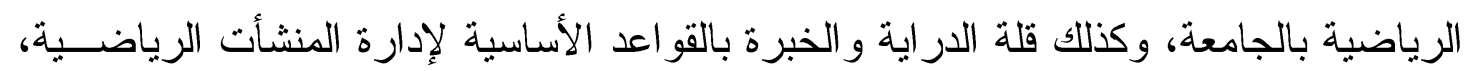

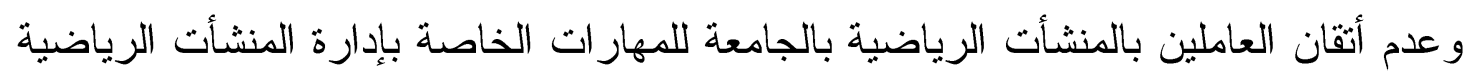

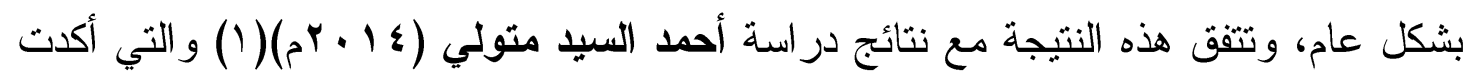

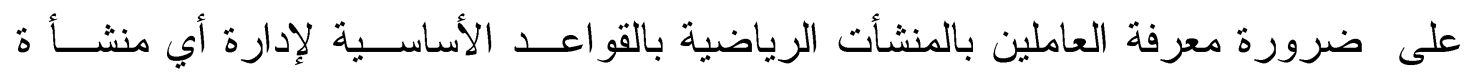

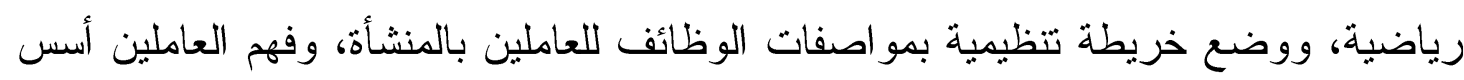
تخطيط الميز انيات و التمويل للمنشأة الرياضية، مع أثقان المهار ات الخاصة باتبات بإدارة المنشأة.

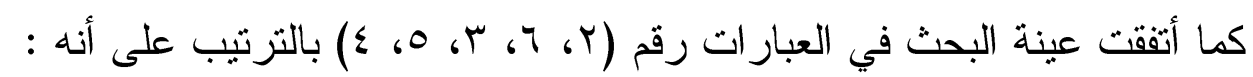
- يوجد إلى حد ما قسم خاص بالتخطيط للمنشأت الرياضية بالجامعة.

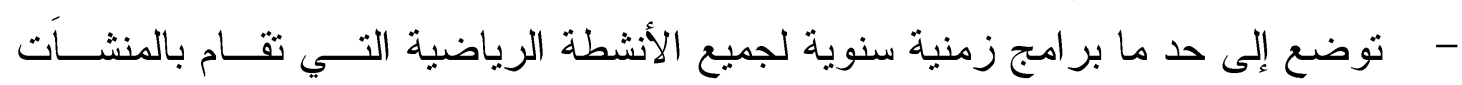
الرياضية بالجامعة. - توضع إلى حد ما خطط لتدريب العاملين بالمنشآت الرياضية. مجلة أسيوط لعلوم وفنوز التربية الرياضية 
- - البر امج الزمنية التي توضع داخل المنشات الرياضية تكون قابلة للتعديل إلى حد ما. - مشاركة العاملين فى عملية التخطيط يساعد إلى حد ما على التنفيذ الجيد للخطط.

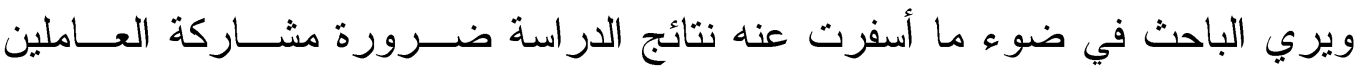
بالمنشأت الرياضية في وضع الخطط، وكذلك مشاركتهح و أخذ آر ائهم فيما يتعلق بالعمل حتى يشعرون بالدور الإيجابي لهم في العمل، وبالتالي سوف يكون هناك و لاء للمنشأة مسـن قبـلـل هؤلاء العاملين، وكذلك مر اعاة المرونة عند وضـع الخطط و البر امج الزمنية مــن قبــل إدارة

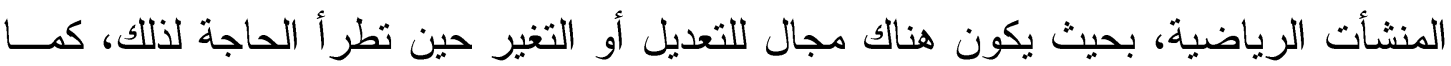
يجب الوضع في عين الأعتبار وضع خطط وبر امج زمنية من حين لأخر لتـدريب العـاملين على مهار ات إدارة المنشأت الرياضية. المحور الثالث : الأمكانات

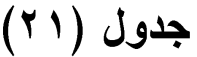

الارجة المقدرة والنسبة المئوية لأستجابات عينة البحث في المحور الثالث الأمكانات $(100=\dot{0})$

\begin{tabular}{|c|c|c|c|}
\hline المئوية & 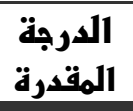 & العبـــــارات & م \\
\hline$\% \vee r . \leq 1$ & 079 & عدد المنشات الرياضية يتتاسب مع عدد الممارسين للرياضة بالجامعة. & 1 \\
\hline$\% V \cdot . r r$ & $0 \leqslant 0$ & عدد المنشات الرياضية يتتاسب مع عدد الأنشطة الرياضية التى تمارس بالجامعة. & $\begin{array}{r}r \\
\end{array}$ \\
\hline$\% \vee \vee . Y q$ & 099 & توجد مساحات شاغرة بالمنشات الرياضية بمكن أستثمار ها لزيادة العائد المادي. & $r$ \\
\hline$\% \vee \cdot . \wedge r$ & $0 \leqslant 9$ & تيكفي تلكأو الاعمال. محدة لعمليات الصيانة الدورية للمنشات الرياضية، و الدعم المــالي & $\varepsilon$ \\
\hline$\% \vee \cdot .01$ & $0 \leqslant V$ & 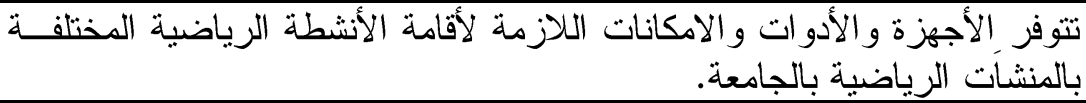 & 0 \\
\hline$\% \vee r . \leqslant q$ & rA. $q$ & ع المحور & \\
\hline
\end{tabular}

يتضح من جدول (Y) أن النسبة المئوية لأستجابات عينة البحث في عبار ات المحور

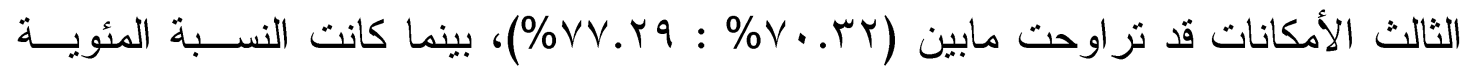

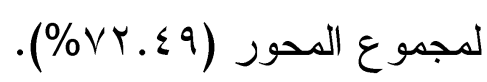

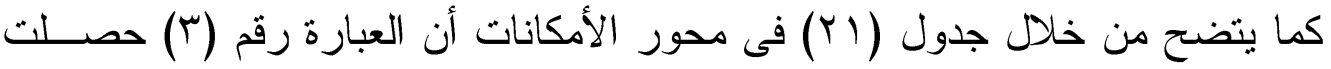

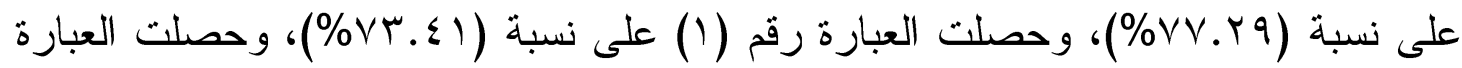

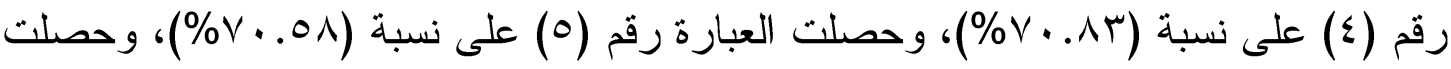

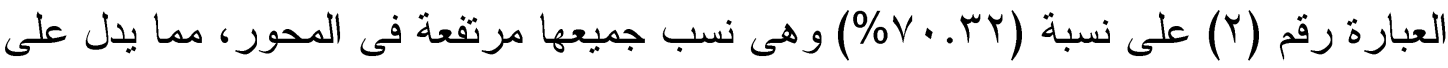

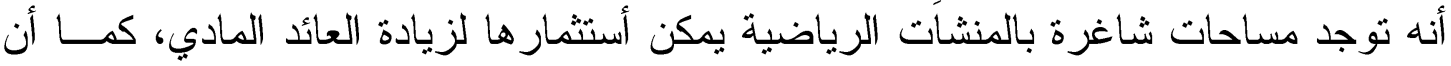

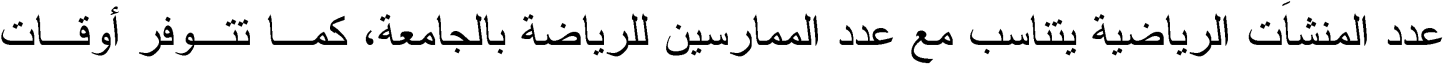


محددة لعمليات الصيانة الدورية للمنشآت الرياضية، كما تتوفر الأجهزة والأدوات والأمكانات

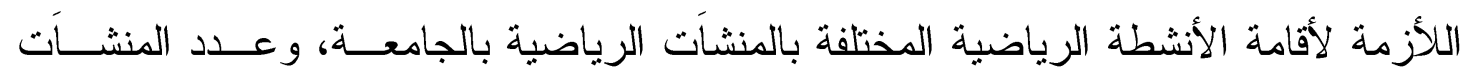

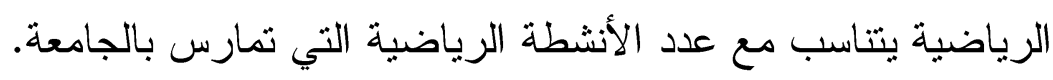

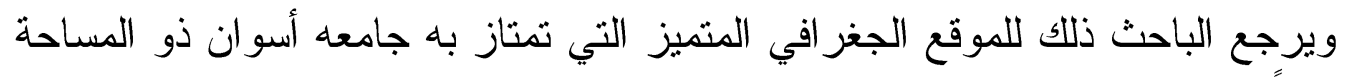

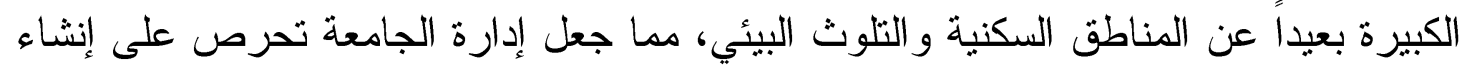

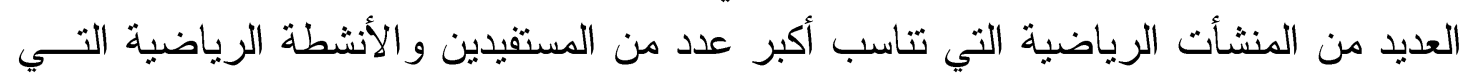

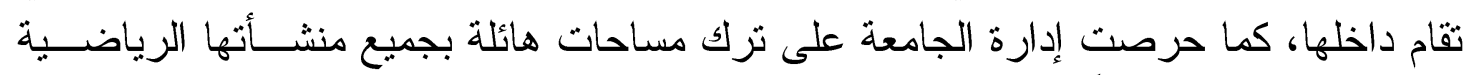

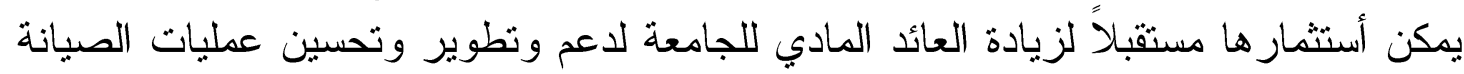

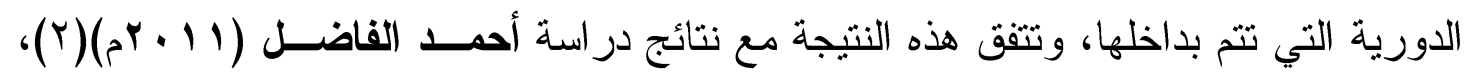

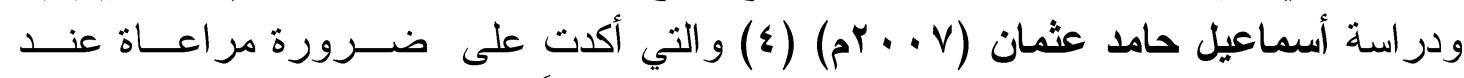

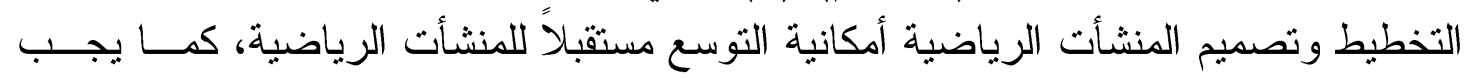
تصميم المنشأت الرياضية بما بتتاسب و أعداد المستفيدن منها، و الحفاظ على الصيانة المبانة المستمرة لالمنشأة.

ويري الباحث في ضوء ما أسفرت عنه نتائج الدراسة ضرورة الحفاظ على المنشأت

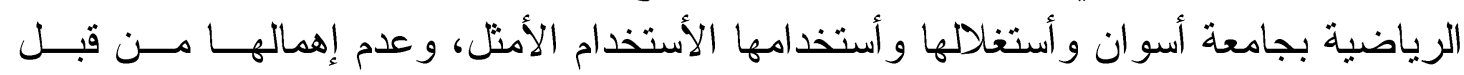

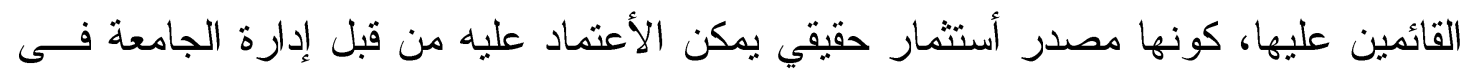

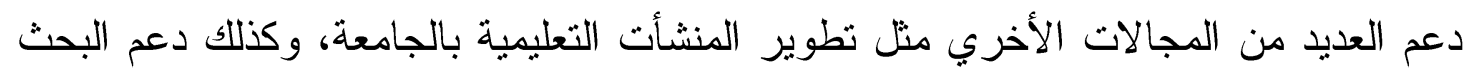
العلمي. - معي.

المحور الرابع : التنظيم

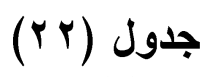

الارجة المقدرة والنسبة المئوية لأستجابات عينة البحث في المحور الرابع التنظيم

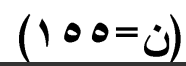

\begin{tabular}{|c|c|c|c|}
\hline المئوية & المقدرة & العبـــــارات & م \\
\hline$\% \circ 9 . \varepsilon \wedge$ & $\leq 71$ & يتيت أختيار القائمين على إدارة المنشات الرياضية بالجامعة على أســاس الخبــرة & 1 \\
\hline$\% \vee Y . r \wedge$ & 071 & بالجمامعة. توزيع الأختصاصات و المسئوليات علــى العـاملين بالمنشــات الرياضـــة & r \\
\hline$\% 77.19$ & 011 & 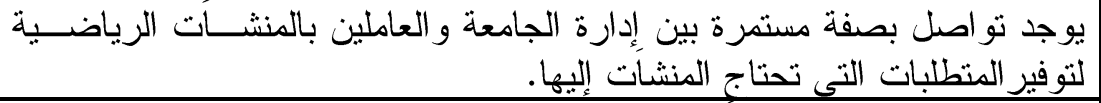 & r \\
\hline$\% \circ \wedge . \vee \cdot$ & $\leq 00$ & يتم تقويض العاملين بالمنشات الرياضية لأنجاز بعض المهام. & $\varepsilon$ \\
\hline$\% \vee \leqslant . \leqslant 0$ & OVV & يساعد التنظيم على تحسين مستوى العلاقات بين العاملين بالمنشات الرياضية. & 0 \\
\hline$\% \vee Y .9$. & 010 & يعمل التنظيم الجيد على حسن سير العمل بالمنشات الرياضية بالجامعة. & 7 \\
\hline$\% 70 . \leqslant 1$ & $r \cdot \xi r$ & & \\
\hline
\end{tabular}

مجلة أسيوط لعلوم وفنون التربية الرياضية 
يتضح من جدول (Yr) أن النسبة المئوية لأستجابات عينة البحث في عبار ات المحور

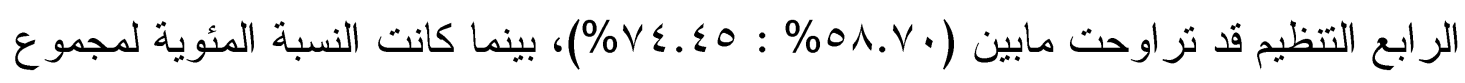

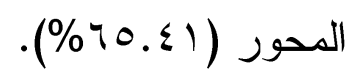

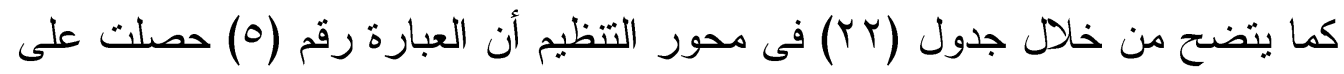

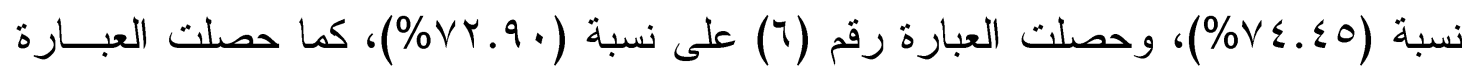

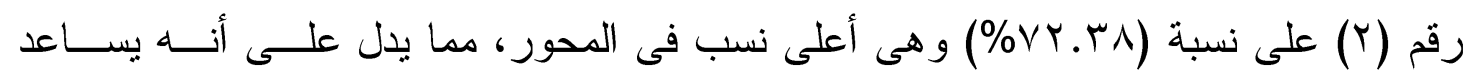

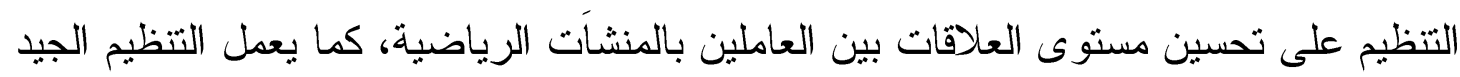

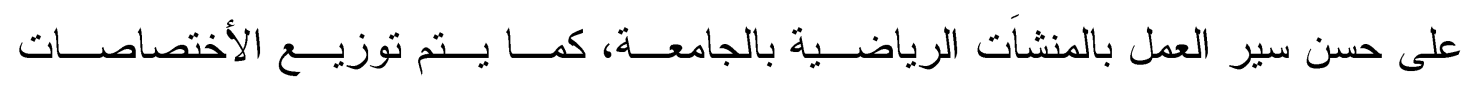

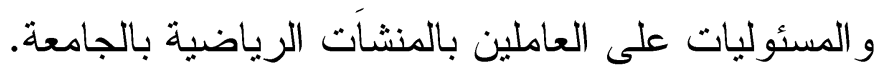

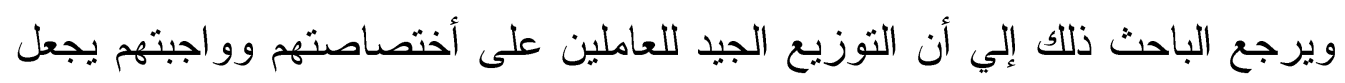

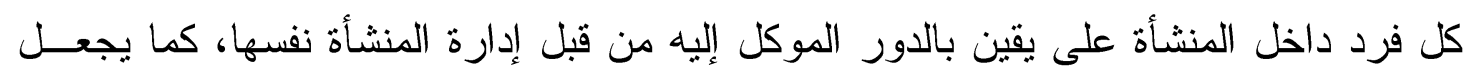

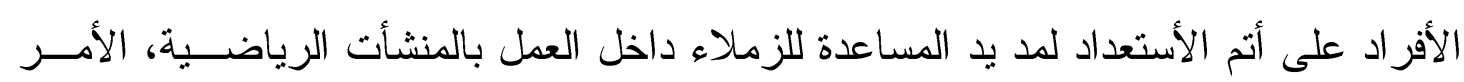

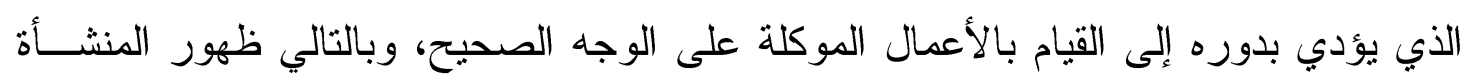

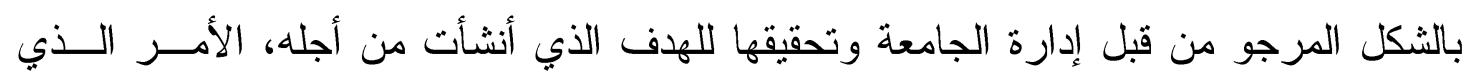

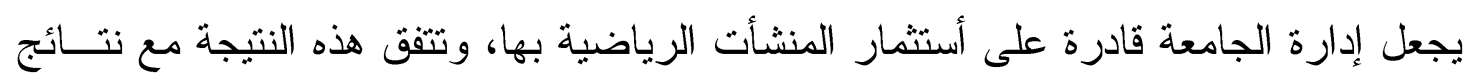

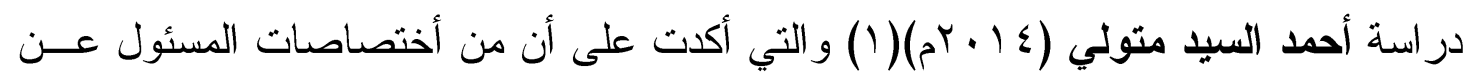

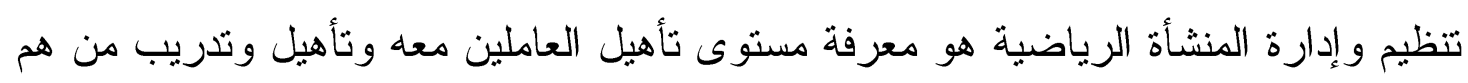

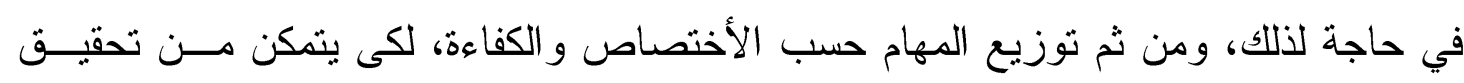
الهدف الذي من أجله وجدت المنشأة الرياضية.

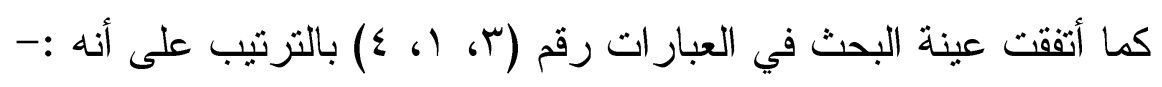

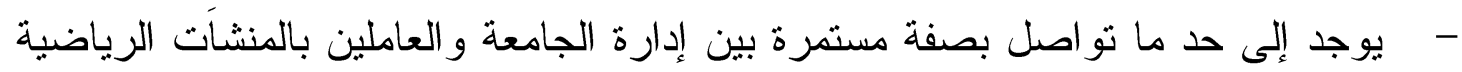
لتوفير المنطلبات التي تحتاج المنشأت إليها.

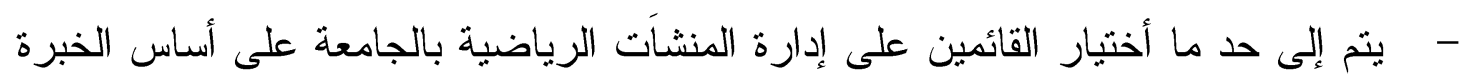
و التخصص.

- - ميتم إلى حد ما تفويض العاملين بالمنشأت الرياضية لأنجاز بعض المهام.

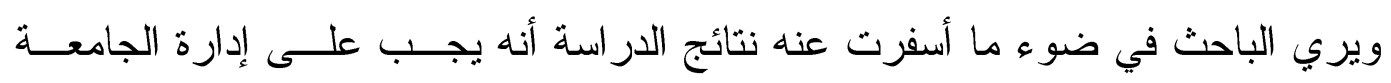

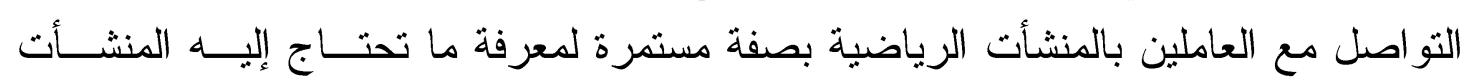

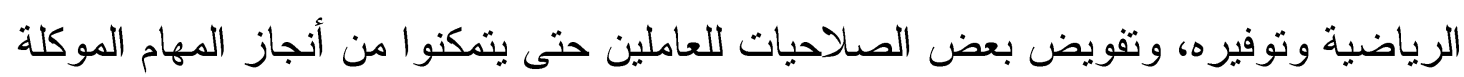


إلبهر دون تعطيل وبما لا يؤثر على مصلحة العمل، كما يجب أختبار إدارة المنشأت الرياضية على أساس التخصص و الخبر ات السابقة لهم في مجال المنشأت الرياضية.

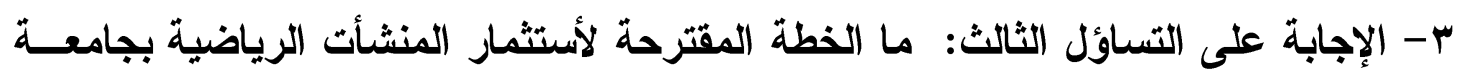
أسوان

من خلال ما توصل إليه الباحث من نتائج، قام الباحث بوضع خطة مقترحسـة لأســتثمار المنشأت الرياضية بجامعة أسوان، كما هو موضح في جدول (بr). جدول (r)

الخطة المقترحة لأستثمار المنشأت الرياضية بجامعة أسوان

\begin{tabular}{|c|c|}
\hline المهتوى & المهور \\
\hline 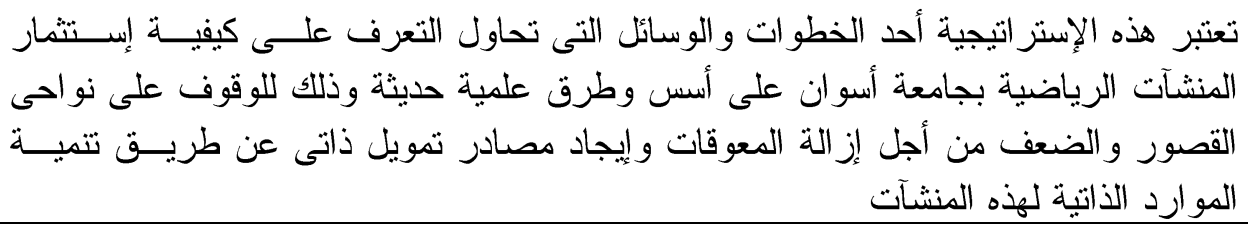 & رؤية الخطة \\
\hline 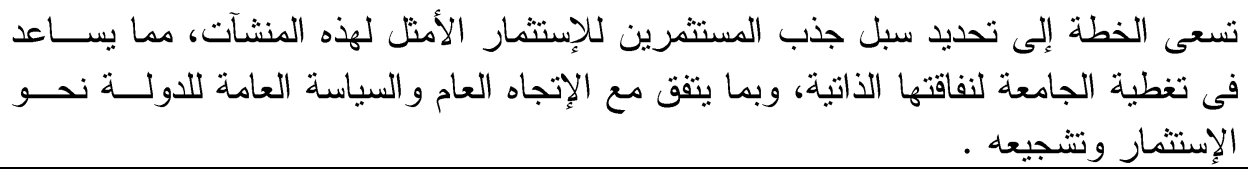 & رسالة الخطة \\
\hline 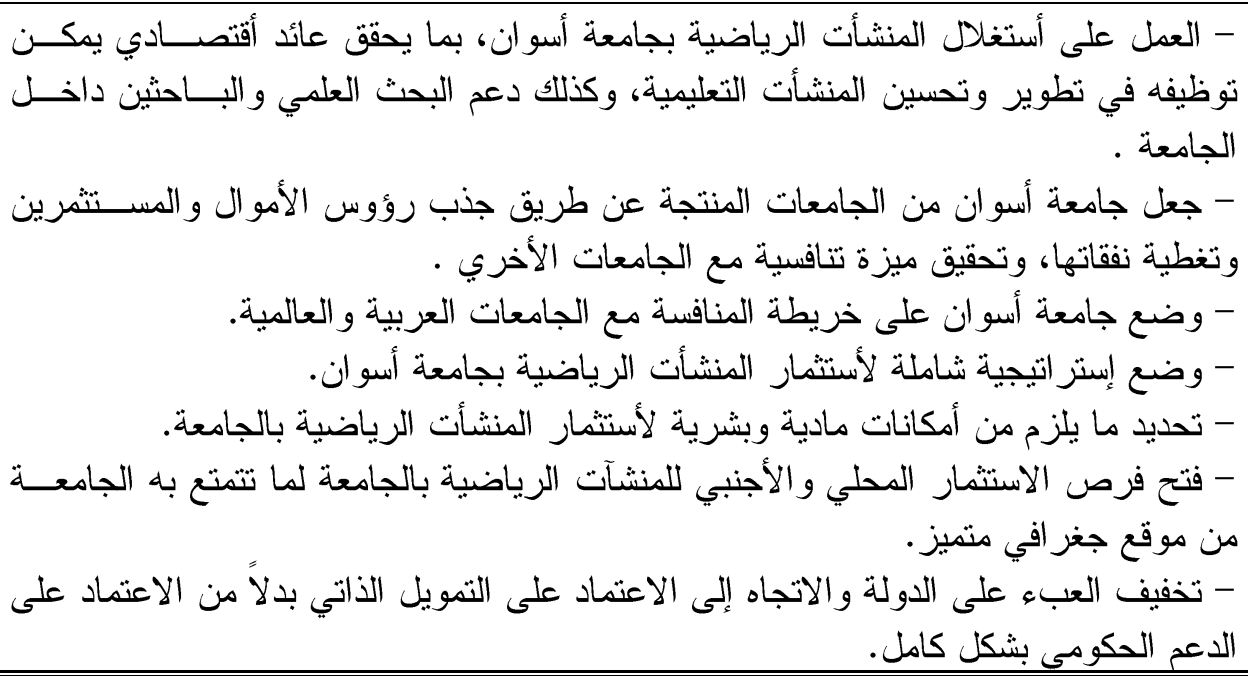 & أخطة أهــــــــاف \\
\hline 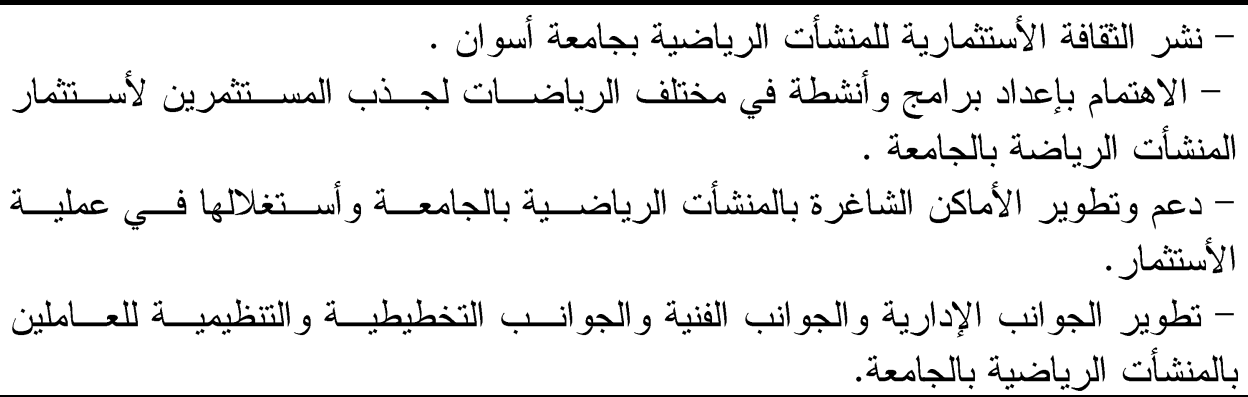 & العامة للخطة \\
\hline
\end{tabular}

مجلة أسيوط لعلوم وفنون التربية الرياضية 


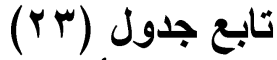

الخطة المقترحة لأستثمار المنشأت الرياضية بجامعة أسوان

المهتوى

المهور

- - البنية التحتية للمنشأت الرياضية بالجامعة .

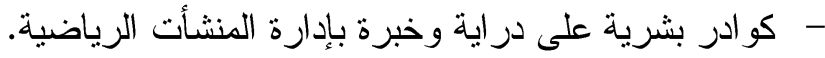

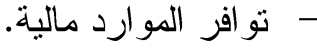
- مقومات طبيعية وجغر افية.

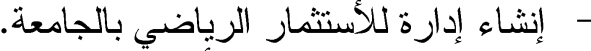
- - إنشاء إدارة خاصة بالمنشأت الرياضية الراضية بجامعة أسوان. مقومــــات الخطة - - إنشاء قسم خاص للتخطيط للبر امج و الأنشطة بالمنشأت الرئنة الرياضية. - - التسويق و الأعلان عن المنشأت الرياضية بالجامعة (إدارة العلاقات العالئات العامة).

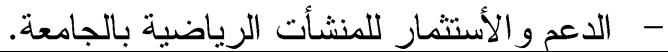

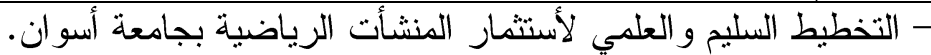

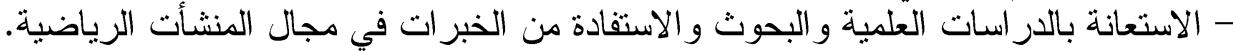

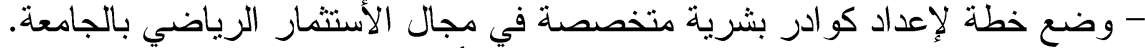

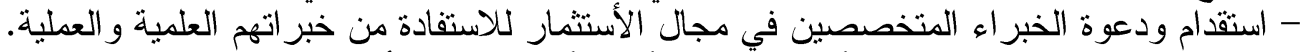

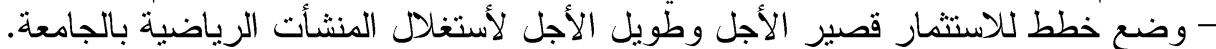

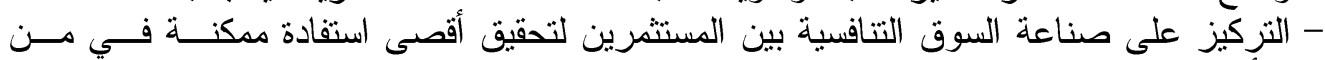

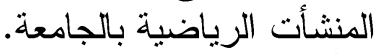

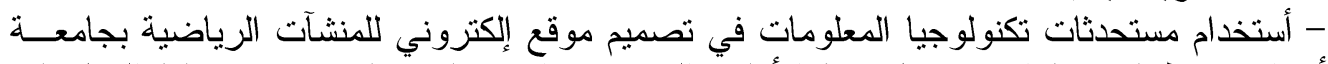
أسوان وربطها بشبكة الإنترنت لمعرفة الأماكن التى يمكن الإستثمار فيها، مع توفير كافة لإنة المعلومات المات

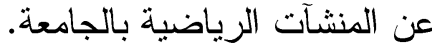
- إعداد قو انين خاصة بالإستثمار الرياضي في اللائحة الداخلية للجامعة تكفل تحقيـق الإســتثار

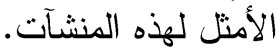
- العمل على مرونة الخطط الموضوعة الأل الأستثمار المنشآت الرياضية، ومشاركة العاملين بالمنشآت

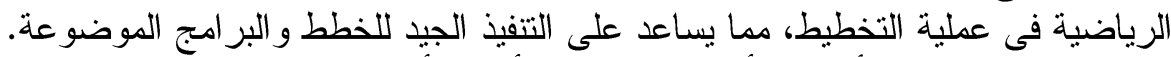

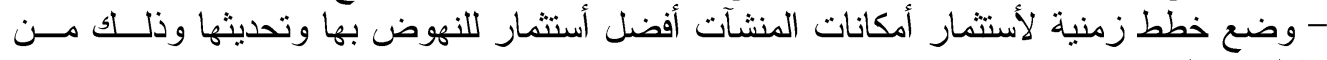

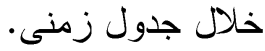

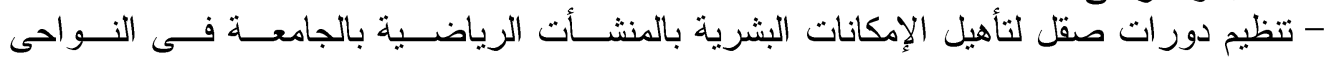

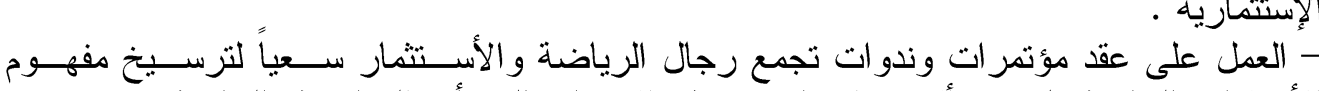

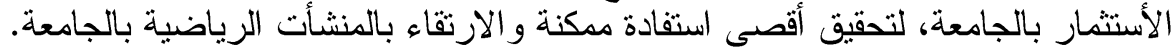

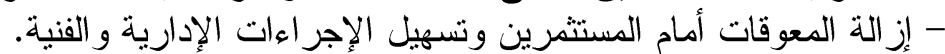

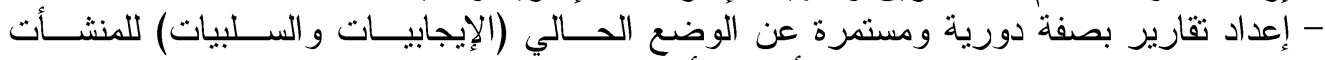

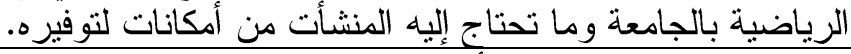

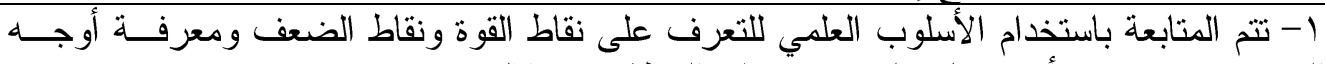

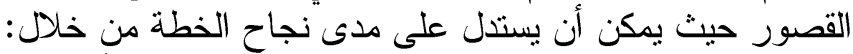

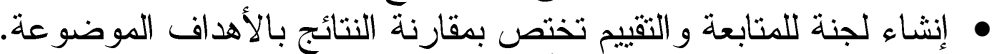
• مدى مناسبة الإمكانات و المنشأت و عددها لمنطلبات و إحتياجات الأفر اد و المستفيدين و المستثمرين

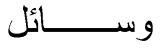

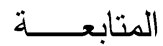
و التثقيم

r- العمل على حل المشكلات التى تو اجه عملية التنفيذ أول بأول. جهة التنفيذ إمعة أسوان. 


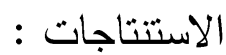

أستنتاجات التساؤل الأول الخاصة بواقع خطط الأستثمار الرياضـــــالمنشــأت الرياضــية بجامعة أسوان:

1- استنتاجات المحور الأول: الجوانب القانونية والتشريعية:-

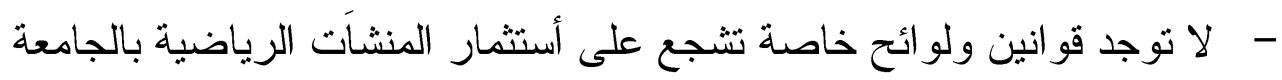
r- أستنتاجات المحور الثاني: الجو انب الإدارية:-

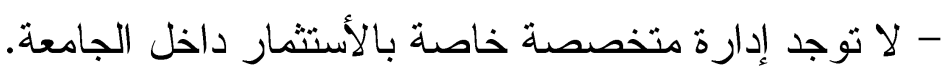
r- أستنتاجات المحور الثالث: الجوانب الفنية:-

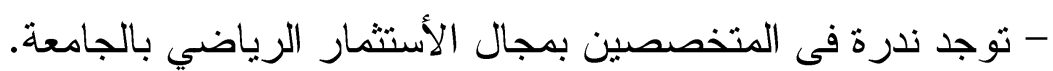

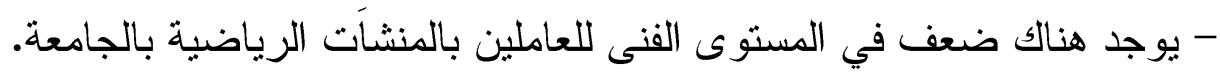

ع - أستنتاجات المحور الرابع: جوانب الوعي بالاستثمار الرياضي:-

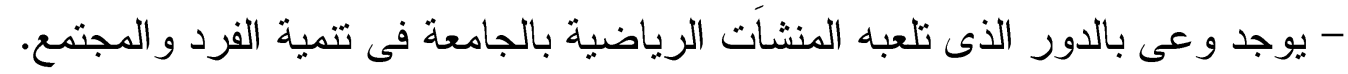

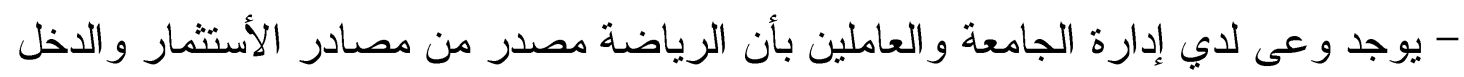
اللاولة و المؤسسات التعليمية.

ه- أستنتاجات المحور الخامس: جوانب الؤسي بالسياسة الرياضية:-

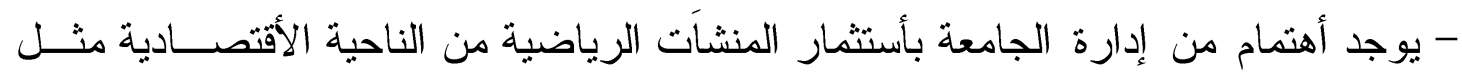

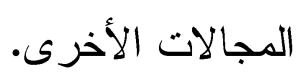

أستنتاجات التساؤل الثاني الخاصة بواقع أداء المنشأت الرياضية بجامعة أسوان: 1- استنتاجات المحور الأول: المفاهيم:-

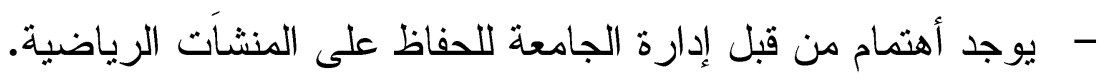

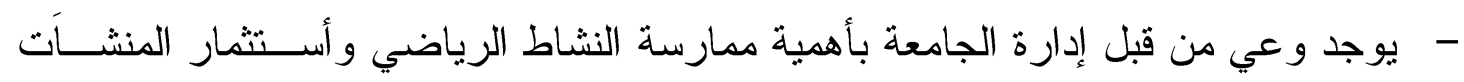
الرياضية بالجامعة.

r- أستنتاجات المحور الثاني: التخطيط:-

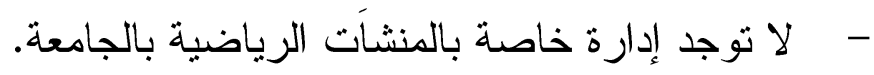

r- أستنتاجات المحور الثاني: الأمكانات:- توجد مساحات شاغرة بالمنشأت الرياضية بمكن أستثمار ها لزيادة العائد المادي.

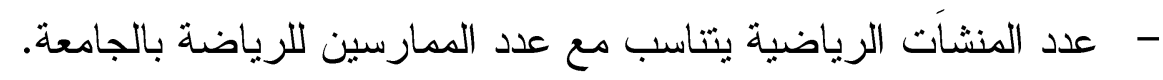
ع - أستنتاجات المحور الثاني: التنظيم:- 
- يساعد التنظيم على تحسين مستوى العلاقات بين العاملين بالمنشأت الرياضية. - يعمل التظظيم الجيد على حسن سير العمل بالمنشاًت الرياضية بالجامعة. التوصيات:

في ضوء استنتاجات البحث التي تحقق أهدافه توصل الباحث إلى التوصيات التالية:

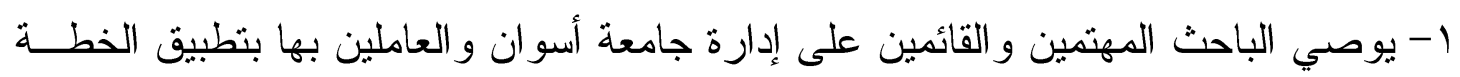
المقترحة و الاسترشاد بها من أجل النهوض بالمنشأت الرياضية بالجامعة. ץ- ضرورة العمل على اسثثمار المنشآت الرياضية بجامعة أسوان وأسثثمار الأماكن الثاغرة

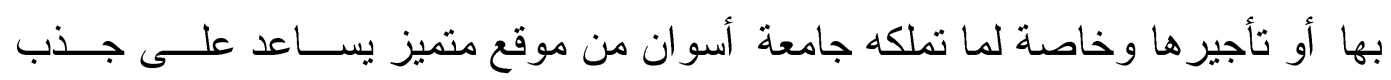
المستثرين.

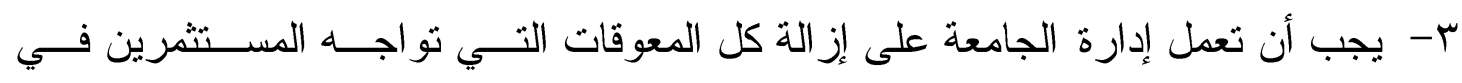
الجو انب القانونية و التشريعية و الجو انب الإدارية و الفنية وتسهيل الإجر اءات و التصاريح اللازمة لتشجيع المستثرين على الأستثمار في المنشآت الرياضية بجامعة أسوان.

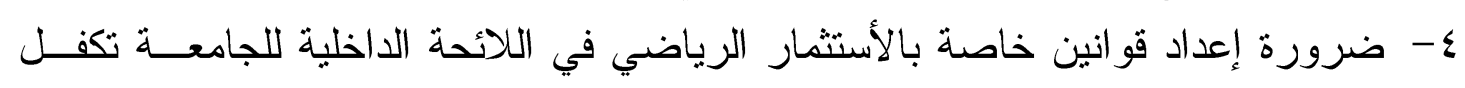
تحقيق الأستثمار الأمثل لهذه المنشآت.

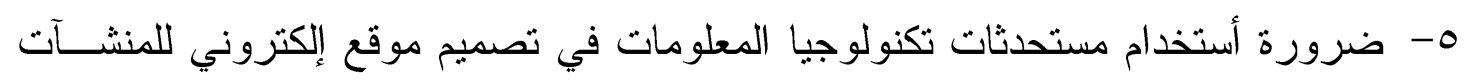
الرياضية بجامعة أسوان وربطها بشبكة الإنترنت لمعرفة الأماكن التى يمكن الإســتثمار فيها، مع توفير كافة المعلومات عن المنشآت الرياضية بالجامعة للمستثرين.

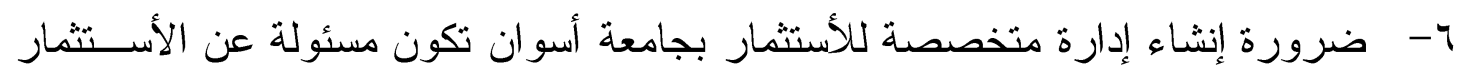

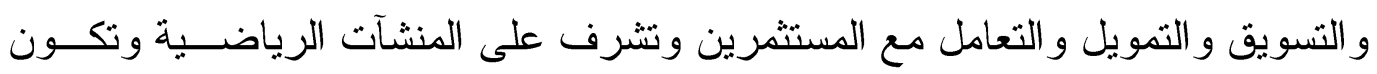
مسئولة عن التحديث و التطوير و الصيانة المستمرة والتوسع في إقامة المنشآت الرياضية داخل الجامعة. - V - على إدارة الجامعة الأهنمام بعقد الدورات التدريبية بصفة مســمرة فـي مجــال إدارة

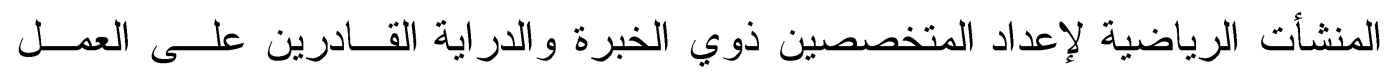
بالمنشآت الرياضية.

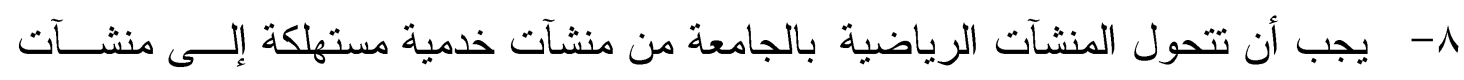
خدمية منتجة تساهم في الاقتصاد القومي. 9- ضرورة وضع خطة لإعداد كو ادر بشرية متخصصة في مجال الأســثمار الرياضــي بالجامعة. 


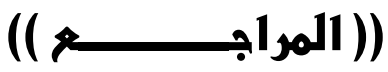

1- أحمد السيد محمود: اليات تطوير إدارة المنشأت الرياضية بجمهورية مصر العربية، المجلة العلمية للتربية البدنية و علوم الرياضة، كلية التربية الرياضية للبنين،

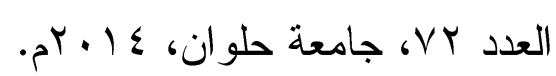

ץ- أحمد الفاضل: تصميم وتخطيط المنشأت الرياضية، بحث علمي منشور، جامعة الملك

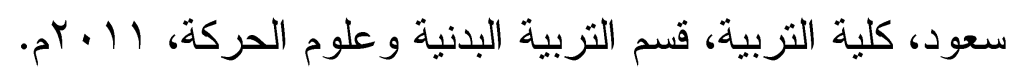

ب- أحمد عرفه، سمية شلبي: الإدارة الإستراتيجية للتسويق فى صراع العولمة، مكتبة

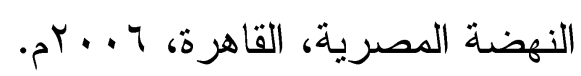

ع - أسماعيل حامد عثمان: التخطيط للمنشأت الرياضية، بحث علمي منشور، كلية التربية

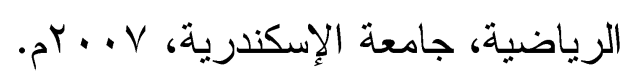

0- أثرف محمود حسين: معوقات الإستثمار في المجال الرياضي في ج.م·ع، رسالة

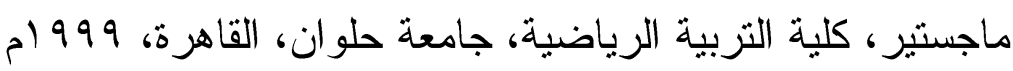
ج- إيمان زكي محمد، يحيي فكرى محمد: تقويم التمويل الذاتي فى الاتحادات الرياضية الأولمبية، المصرية، مجلة نظريات وتطبيقات كلية التربية الرياضية للبنين،

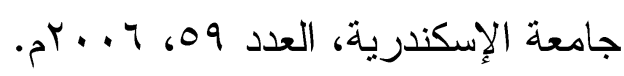

- إيمان محمد أحمد: إستراتجية مقترحة لاستثمار أنشطة الاتحاد المصري لكرة اليد بجمهورية مصر العربية، رسالة دكتوراه غير منشورة، كلية التربية

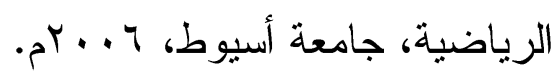

1- المجلس القومي للرياضة: لائحة القو اعد المنظمة لإدارة وتشغيل المنشآت الرياضية

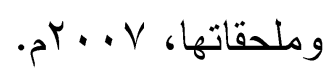

9- جمال محمد على: الحديث فى الإدارة الرياضية، دار الفكر العربي، القاهرة، 9 ه. . بم. • 1- حسام حسن شحاته: نظام مقتر ح للاستثمار في بعض الأندية الرياضية المصرية، رسالة

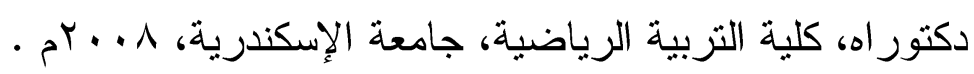

ا ا-حسن أحمد الثافعي: الاستثمار والتسويق في التربية البدنية و الرياضية (الموسوعة

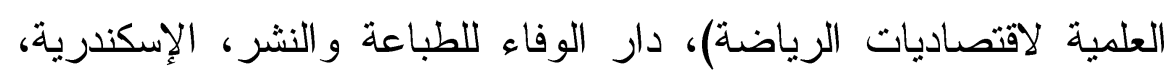

$$
\text { . }
$$

Y ا- حليمة زيد محمد: تقييم إستثمار ات القطاع الخاص في مجال التعليم و اتجاهات تطويره

$$
\text { بدولة الإمار ات، القاهرة، } 0 \text {. . بام. }
$$


با - خالد السيد أحمد: تقويم مصادر تمويل الأندية الرياضية لمحافظة الثرقية، رسالة

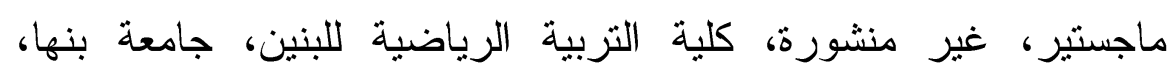

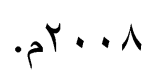

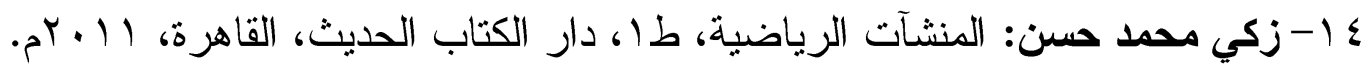

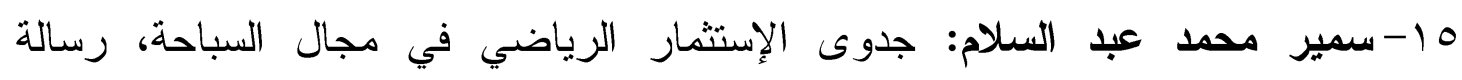

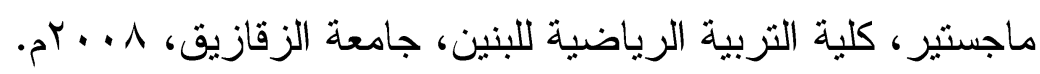

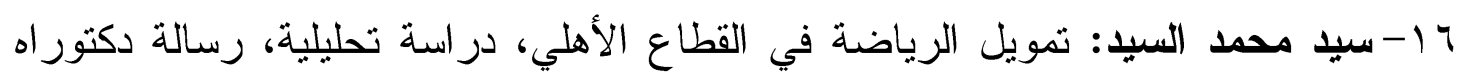

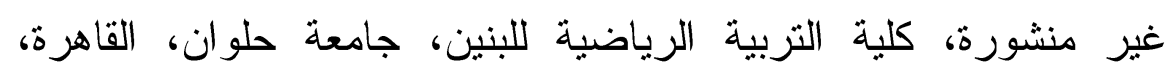

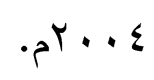

IV

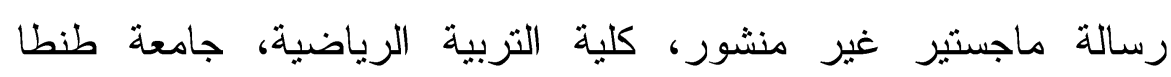

$$
\text { مr }
$$

11-ضياء الاين محمد العزب: محاضرات في المنشآت الرياضية الدورة الأولي لإعداد

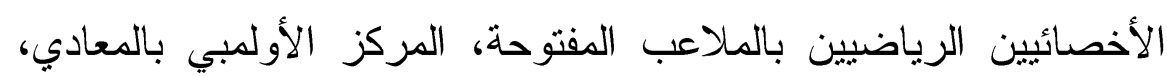

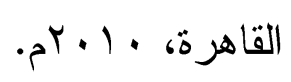

9 1 - عطيه سعد الثبراخيتي: استثمار الأندية المصرية لنشاط رياضة كرة القدم اقتصاديا،

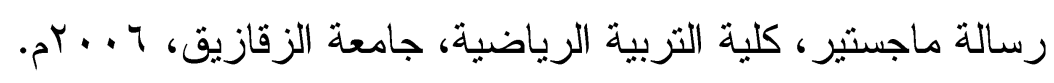

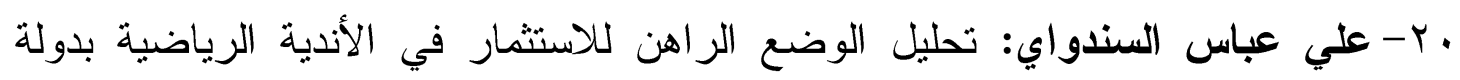

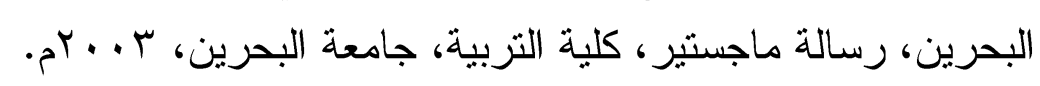

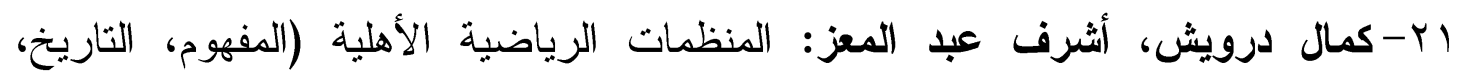

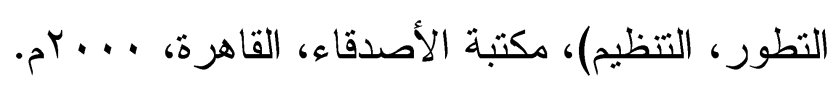

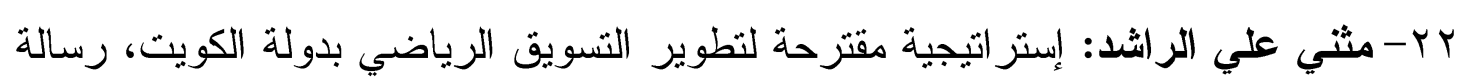

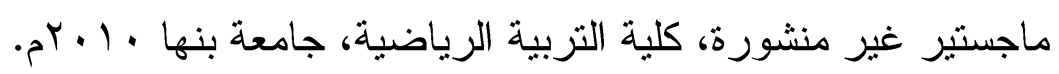

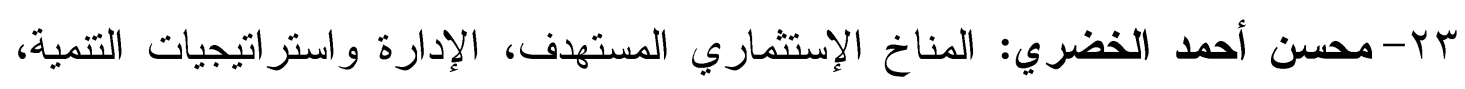

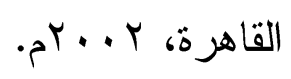

ع ب-محمد عبد العظيم محمود: خطة مقترحة لإدارة المؤسسات الرياضة وفقاً للأهداف

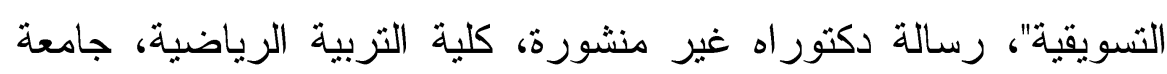

$$
\text { أسيوط، } 1 \text { + . ب م. }
$$


هب-محمد فتحي محمد: جودة المعلومات و أثرها في عملية صنع القرار داخل المنشأت الرياضية بمحافظات جنوب الصعيد، المجلة العلمية للتربية البننية وعلوم

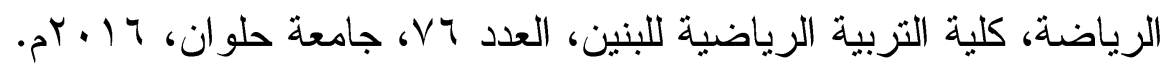
צr-معتز مصطفي عبد الجواد: مدخل إداري معاصر لإستثمار المؤسسات الرياضية، رسالة

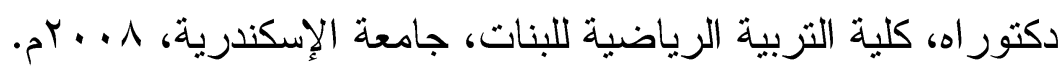

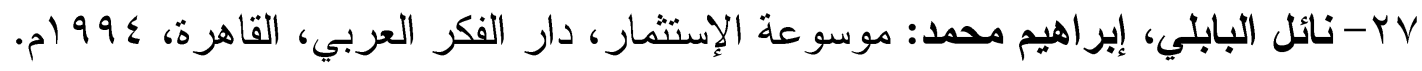

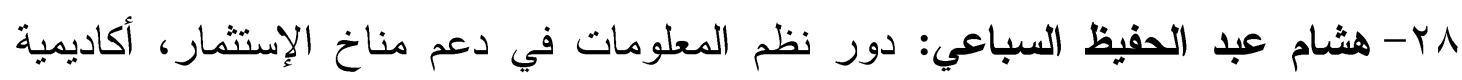

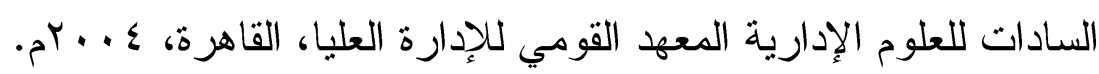
qץ- يحيي بلر مبارك فاتح: إستر اتيجية مقترحة لجذب رؤوس الأمو ال للإستثمار في الأندية

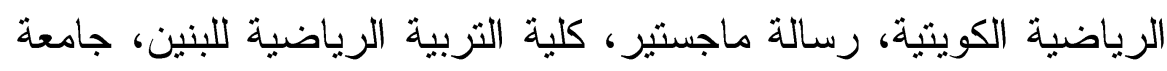

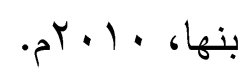

